\title{
1 Nanomaterials for sustainable remediation of chemical contaminants in water and soil
}

2 Raj Mukhopadhyay ${ }^{\mathrm{a}}$, Binoy Sarkar ${ }^{\mathrm{b}, *}$, Eakalak Khan ${ }^{\mathrm{c}}$, Daniel S. Alessi ${ }^{\mathrm{d}}$, Jayanta Kumar Biswas ,

3 K. M. Manjaiah ${ }^{\mathrm{f}}$, Miharu Eguchi ${ }^{\mathrm{g}}$, Kevin C.W. Wu ${ }^{\mathrm{h}}$, Yusuke Yamauchi ${ }^{\mathrm{i}, \mathrm{j}}$, Yong Sik Ok ${ }^{\mathrm{k}, *}$

$4 \quad{ }^{a}$ Division of Irrigation and Drainage Engineering, ICAR-Central Soil Salinity Research Institute, Karnal

$5 \quad$ - 132001, Haryana, India

$6 \quad{ }^{b}$ Lancaster Environment Centre, Lancaster University, Lancaster, LA1 4YQ, United Kingdom

$7 \quad{ }^{c}$ Department of Civil and Environmental Engineering and Construction, University of Nevada, Las

$8 \quad$ Vegas, NV 89154, USA

$9{ }^{d}$ University of Alberta, Earth and Atmospheric Sciences, Edmonton, AB, T6G 2E3, Canada

$10{ }^{e}$ Department of Ecological Studies \& International Centre for Ecological Engineering, University of

11 Kalyani, Kalyani, Nadia- 741235, West Bengal, India

$12 \quad{ }^{f}$ ICAR-Indian Agricultural Research Institute, New Delhi-110012, India

$13{ }^{g}$ Electronic Functional Materials Group, National Institute for Materials Science (NIMS), 1-1 Namiki,

14 Tsukuba, Ibaraki 305-0044, Japan

$15{ }^{h}$ Department of Chemical Engineering, National Taiwan University, Taipei 10617, Taiwan

$16{ }^{i}$ Australian Institute for Bioengineering and Nanotechnology (AIBN) and School of Chemical

17 Engineering, The University of Queensland, Brisbane, QLD 4072, Australia

$18{ }^{j}$ Yamauchi Materials Space-Tectonics Project and International Center for Materials

19 Nanoarchitechtonics (WPI-MANA), National Institute for Materials Science (NIMS), 1-1 Namiki,

20 Tsukuba, Ibaraki 305-0044, Japan

$21{ }^{k}$ Korea Biochar Research Center, APRU Sustainable Waste Management Program \& Division of

22 Environmental Science and Ecological Engineering, Korea University, Seoul 02841, Republic of Korea

$23{ }^{*}$ Co-corresponding authors:

24 Dr. Binoy Sarkar, Lancaster University, e-mail: b.sarkar@lancaster.ac.uk

25 Prof. Yong Sik Ok, Korea University, e-mail: yongsikok@korea.ac.kr 


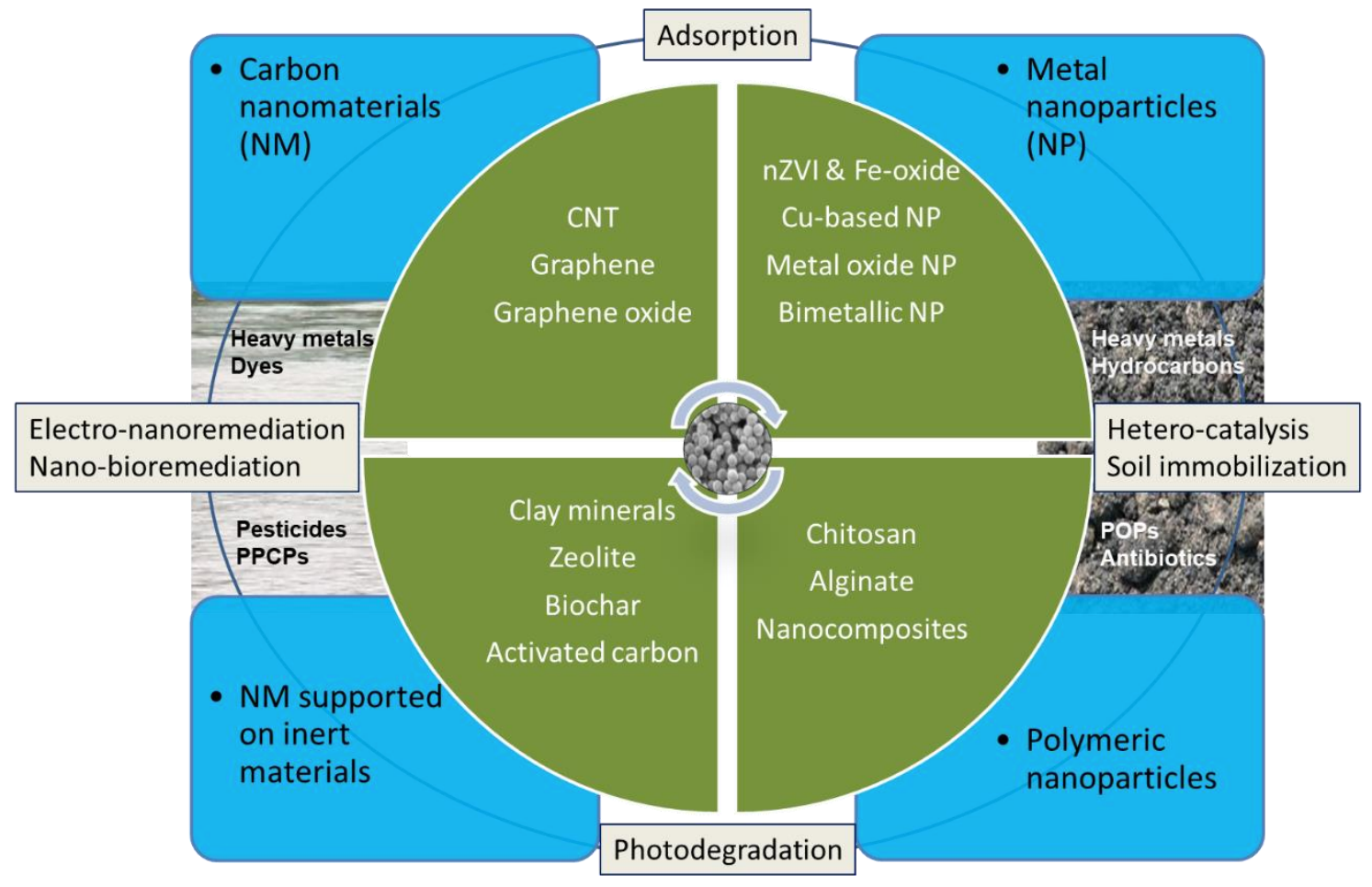




\section{Abstract}

Rapid growth in population, industry, urbanization and intensive agriculture have led to soil and water pollution by various contaminants. Nanoremediation has become one of the most

32 successful emerging technologies for cleaning up soil and water contaminants due to the high reactivity of nanomaterials (NMs). Numerous publications are available on the use of NMs for

34 removing contaminants, and the efficiencies are often improved by modifications of NMs with polymers, clay minerals, zeolites, activated carbon, and biochar. This paper critically reviews the current state-of-the-art NMs used for sustainable soil and water remediation, focusing on their applications in novel remedial approaches, such as adsorption/filtration, catalysis, photodegradation, electro-nanoremediation, and nano-bioremediation. Insights into process

39 performances, modes of deployment, potential environmental risks and their management, and the consequent societal and economic implications of using NMs for soil and water remediation

41 indicate that widespread acceptance of nanoremediation technologies requires not only a

42 substantial advancement of the underpinning science and engineering aspects themselves, but

43 also practical demonstrations of the effectiveness of already recognized approaches at real world

44 in-situ conditions. New research involving green nanotechnology, nano-bioremediation, electro-

45 nanoremediation, risk assessment of NMs, and outreach activities are needed to achieve

46 successful applications of nanoremediation at regional and global scales.

47

48 Key Words: Environmental protection; Green and sustainable remediation; Sustainable

49 development goals; Soil remediation; Soil pollution; Wastewater treatment 


\section{Introduction}

51 One of the biggest problems faced currently by most countries in the world is the deterioration of

52 environmental quality due to wastewater generation, groundwater contamination, and land

53 degradation. Providing a clean environment to humankind is a major challenge to the global

54 community. The challenges of contaminated environment are represented by the United Nation's

55 Sustainable Development Goals (SDGs): 'Clean Water and Sanitation', 'Life on Land', and 'Life

56 Below Water' (UN, 2016).

57 Continuous accumulation of toxic trace elements in soil and water environments accelerate their

58 bioaccumulation. Human exposure to cadmium $(\mathrm{Cd})$, lead $(\mathrm{Pb})$, arsenic $(\mathrm{As})$ and fluoride $(\mathrm{F})$ via

59 drinking water and the consumption of contaminated food can lead to severe health problems in

60 the skin, lungs, kidneys and brain (Schaefer et al., 2020; Wang et al., 2019). Organic

61 contaminants such as industrial dyes are difficult to treat due to their recalcitrance and sensitivity

62 on physicochemical properties of the surrounding environment for degradation (Lellis et al.,

63 2019). Likewise, the excessive application of pesticides in agriculture has contaminated soil and

64 water resources globally (de Souza et al., 2020). Anthropogenic and natural activities including

65 coal gasification, coal-tar pitches and open burning can produce large quantities of polycyclic

66 aromatic hydrocarbons (PAHs) due to the incomplete combustion of hydrocarbons (Li et al.,

67 2020). Pharmaceuticals and personal care products (PPCPs) are contaminants of emerging

68 concern found in wastewater due to discharge from households, healthcare facilities, and the

69 pharmaceutical manufacturing industry (Meyer et al., 2019).

70 There is a need to develop cost-effective and ecologically benign materials for cleaning up

71 contaminated soil and water. Nanotechnology offers rapid, inexpensive and environmentally safe

72 solutions, and has great potential to reduce contaminant levels to 'nearly zero' (Bardos et al., 
73 2018). Nanoremediation of the environment can be defined as the process whereby suitable

74 nanomaterials (NMs) are used for cleaning up environmental contaminants in the soil, water, and

75 air. Nanoremediation technologies can eliminate the need for excavating and transporting

76 contaminated soils because the cleanup process often takes place in-situ (Cai et al., 2019; Fajardo

77 et al., 2020). Furthermore, several approaches can be applied to regenerate and reuse

78 nanomaterials in contaminant treatment applications (e.g., magnetic separation of iron

79 nanoparticles, recovery of metals from spent nanosorbents) (Mehta et al., 2015).

80 Nanoparticles (NPs) are particles with sizes of <100 nm in all dimensions (e.g., metal oxides),

81 while NMs require only one dimension to be <100 nm (e.g., carbon nanotubes) (Khan et al.,

82 2019). Nanocomposites are defined as multiphase materials consisting of at least one nanoscale

83 phase that is dispersed in another phase to obtain a combination of the individual properties of its

84 constituents (Bassyounia et al., 2019; Mukhopadhyay et al., 2020). Therefore, one of the

85 constituent materials in nanocomposites should have a dimension $<100 \mathrm{~nm}$ (Schaefer and

86 Justice, 2007; Zhao et al., 2011). Nanoscale metal oxides, nano-scale zero valent iron (nZVI),

87 bimetallic nanoparticles (BNPs), carbon nanotubes (CNTs), graphene oxides, silica-based NPs,

88 polymers, clay minerals and zeolites have been shown to decontaminate soil and water (Awad et

89 al., 2020; Mukhopadhyay et al., 2020; Sarkar et al., 2018; Zou et al., 2016). Applications of NMs

90 supported on clay minerals, zeolites, activated carbon and biochar have also improved the

91 reactivity and contaminant removal performances of NMs (Mandal et al., 2018). Reactive

92 nanomaterials can chemically reduce and/or aid in the catalytic reactions to degrade, detoxify

93 and transform specific pollutants (Kumar et al., 2020a). Expediting the cleanup of contaminants

94 in water and soil using NMs holds the potential to improve environmental health for human

95 civilization in meeting multiple SDGs. 
Based on the functions of various NMs, they can be classified as adsorbents (for adsorption of

97 contaminants), catalysts (for degradation/transformation of pollutants) and membranes (pressuredriven technique for wastewater and seawater treatment) (Anjum et al., 2019). However, most of the literature focuses on the remediation of aqueous systems, and most of these studies are at the bench scale. Cleanup of contaminated soils using NMs has received less attention. Multiple technological, societal and economic bottlenecks (e.g., high preparation and implementation costs of NMs, a lack of desired contaminant removal efficiency under in-situ conditions) have hindered the widespread application of nanotechnologies in environmental remediation. No comprehensive critical review is currently available that discusses both water and soil remediation using various types of nanomaterials, their fates and concurrent effects on living organisms, feasibility in field-level applications, environmentally benign and inexpensive synthesis methods, and scientific, societal and economic bottlenecks hindering widespread application, which are addressed for the first time in this work. Specifically, focus has been made on toxic trace elements, pesticides/herbicides, dyes and selected aromatic compounds, which are most encountered in various industrial systems/discharges, wastewater, contaminated irrigation water and agricultural systems.

\section{Nanomaterials for contaminants remediation in water}

Nanomaterials can be grouped into: (i) metal-based or inorganic NMs, (ii) carbonaceous NMs, (iii) polymer-based NMs, and (iv) composite NMs (Guerra et al., 2018). Fig. 1 depicts a schematic representation of various types of NMs used for the removal of environmental contaminants. Metal based NMs (e.g., Fe-based NPs, Cu-based NPs, BNPs) are widely used in environmental remediation followed by carbonaceous NMs (e.g., CNTs, graphene and graphene 
119 oxides), while polymer (e.g., chitosan, alginate) and composite (e.g., clay-polymer

120

121

122

123

124

125

126

127

128 129 as discussed below:

130

131

132

133

134

135

136

137

138

139

140

141

\subsubsection{Iron oxide NPS}

nanocomposites, zeolite and biochar supported) NMs have received considerable research

attention but limited practical applications (Guerra et al., 2018; Mukhopadhyay et al., 2020). Fe-

based NPs have been successfully used in the field, in addition to a few examples of Cu-based

NPs, BNPs, other metal oxide NPs (e.g., $\mathrm{TiO}_{2}, \mathrm{ZnO}$ ) and CNTs. The main motivations for using

NMs for water and soil treatment are: their high selectivity, high adsorption capacity (due to high specific surface area and numerous adsorption sites), and easy regeneration after use.

\section{$2.1 \quad$ Iron-based nanoparticles}

Iron-based NPs include various oxidic NPs (either magnetic or non-magnetic) as well as nZVI,

Iron-based NPs (Fe NPs) such as iron oxides (e.g., hematite $\left(\alpha-\mathrm{Fe}_{2} \mathrm{O}_{3}\right)$, maghemite $\left(\gamma-\mathrm{Fe}_{2} \mathrm{O}_{3}\right)$, and magnetite $\left.\left(\mathrm{Fe}_{3} \mathrm{O}_{4}\right)\right)$ and oxy-hydroxides (e.g., goethite $(\alpha-\mathrm{FeOOH})$ and lepidocrocite $(\gamma$ -

$\mathrm{FeOOH})$ ) were reported to be effective adsorbents of As and other heavy metals (Supplementary Information: Table S1) in water. For instance, a novel nano-adsorbent was prepared by using

$\mathrm{Fe}_{3} \mathrm{O}_{4}$ magnetic core shelled by mesoporous silica (Vojoudi et al., 2017). The obtained material was then modified with bis(3-triethoxysilylpropyl) tetrasulfide and used to remove heavy metals from aqueous solution. The adsorbent removed 303, 256.4 and $270.3 \mathrm{mg} / \mathrm{g}$ of $\mathrm{Hg}(\mathrm{II}), \mathrm{Pd}(\mathrm{II})$ and $\mathrm{Pb}$ (II) ions, respectively (Vojoudi et al., 2017). The magnetic $\mathrm{Fe}_{3} \mathrm{O}_{4} \mathrm{NMs}$ were found suitable for the remediation of aqueous $\mathrm{Cu}^{2+}, \mathrm{Ni}^{2+}, \mathrm{Cd}^{2+}$ and $\mathrm{Zn}^{2+}$. The amount of $\mathrm{Cu}^{2+}, \mathrm{Ni}^{2+}$ and $\mathrm{Zn}^{2+}$ adsorption by $\mathrm{Fe}_{3} \mathrm{O}_{4}$ were $11.5,6.07,9.68$ and $11.1 \mathrm{mg} / \mathrm{g}$, respectively, at $\mathrm{pH} 6.0$ after 50 min of 
142 reaction time (initial metal concentration $=50 \mathrm{mg} / \mathrm{L}$ for each metal ion; adsorbent dose $=6 \mathrm{~g} / \mathrm{L}$ )

143 (Ebrahim et al., 2016). Following modification with 2-mercaptobenzothiazole, magnetic $\mathrm{Fe}_{3} \mathrm{O}_{4}$

144 NPs removed $98.6 \% \mathrm{Hg}$ (II) from a solution that initially contained $50 \mathrm{ng} / \mathrm{mL} \mathrm{Hg}$ (II) in just four 145 minutes through a complexation mechanism, versus $43.7 \%$ removal by the unmodified NPs 146 (Parham et al., 2012). Green-synthesized $\alpha-\mathrm{Fe}_{2} \mathrm{O}_{3}$ NPs using banana peel extracts showed high 147 As(V) adsorption capacity (2.72 mg/g) (Majumder et al., 2019). Similarly, Fe oxide NPs 148 synthesized from green tea leaf extracts removed $13.7 \mathrm{mg} / \mathrm{g}$ As(V) from aqueous solution 149 (Kamath et al., 2020). Fe NPs supported on inert materials such as clay minerals, zeolites and 150 biochar can improve the speed and efficiency of contaminant remediation by enhancing the 151 dispersion of NPs and preventing their passivation and/or degradation (Supplementary 152 Information: Table S1; Section 2.9). Apart from adsorption, Fe oxide NPs such as $\mathrm{Fe}_{2} \mathrm{O}_{3}$ and $153 \mathrm{Fe}_{3} \mathrm{O}_{4}$ can degrade phenol, aniline, and dye compounds via photochemical oxidation reactions 154 (Fig. 2) (Saharan et al., 2014).

\subsubsection{Nano-scale zero valent iron (nZVI)}

157 ZVI $\left(\mathrm{Fe}^{0}\right)$ applied to groundwater was shown to be a strong adsorbing and reducing agent of 158 redox-sensitive contaminants (e.g., Cr(VI), As(III), chloroethylene compounds), and displayed a 159 low toxicity to biota living in the surrounding environment (Chekli et al., 2016). Considering 160 these advantages, researchers have used nZVI for decontaminating oxyanion (e.g., $\mathrm{CrO}_{4}{ }^{2-}$, $161 \mathrm{TcO}_{4}{ }^{-}, \mathrm{AsO}_{3}{ }^{3-} / \mathrm{AsO}_{4}{ }^{3-}$, and $\mathrm{SeO}_{3}{ }^{2-} / \mathrm{SeO}_{4}{ }^{2-}$ ) and oxycation (e.g., $\mathrm{UO}_{2}{ }^{2+}, \mathrm{VO}_{4}{ }^{3-}$ ) contaminants in 162 water (Supplementary Information: Table S1).

163 In some cases, nZVI was further modified to prepare advanced nanoremediation agents. For 164 example, bare nZVI (B-nZVI) was modified with hydroxyethyl cellulose (E-nZVI) and hydroxyl 
165 propylmethyl cellulose (P-nZVI) to remediate dye compounds in water (Wang et al., 2015b). The

166 discoloration efficiency was $93.4,96.3$, and $98.6 \%$ by B-nZVI, E-nZVI, and P-nZVI,

167 respectively, at $0.7 \mathrm{mg} / \mathrm{L}$ initial dye concentration (Wang et al., 2015b).

168 The colloidal forms of ZVI ( $\mu \mathrm{m}$ and $\mathrm{nm}$ particle sizes) can be mixed into natural aquifers to

169 readily degrade or adsorb various pesticides (e.g., alachlor), dyes (e.g., malachite green, reactive

170 yellow) and other organic contaminants (e.g., trichloroethylene, pentachloroethylene) (Lin et al.,

171 2018). The nZVI interacts with heavy metals and metalloids through precipitation (Cu(II), $\mathrm{Pb}(\mathrm{II})$,

$172 \mathrm{Cd}(\mathrm{II}), \mathrm{Co}(\mathrm{II})$ and $\mathrm{Zn}(\mathrm{II})$ ), co-precipitation (Ni(II), Cr(VI), Se(VI)), redox reactions (As(V),

$173 \mathrm{~Pb}(\mathrm{II}), \mathrm{Hg}(\mathrm{II}), \mathrm{Cu}(\mathrm{II}), \mathrm{Ag}(\mathrm{II}) \mathrm{U})$, and adsorption (Cr(VI), Ni(II), Se (VI)) (Pasinszki \& Krebsz,

174 2020). The catalytic activity of nZVI at field conditions can be compromised due to its poor

175 stability and agglomeration behavior (Stefaniuk et al., 2016). However, peroxide free Fenton-

176 type reactions can catalyze organic contaminant degradation to overcome these limitations of

177 nZVI (Pasinszki \& Krebsz, 2020). The agglomeration of nZVI at large scales in aquifers may be

178 problematic as this can cause the clogging of pores and reduce inherent hydraulic conductivity.

179 Hence, future research should be concentrated on the modification of nZVI to reduce its

180 agglomeration behavior at field conditions.

181

$182 \quad 2.2 \quad$ Copper-based nanoparticles

183 Copper based nanoparticles (Cu NPs) have chemical, photocatalytic, optical and electro-thermal 184 properties applicable to remediation. Specifically, copper oxides $\left(\mathrm{CuO}\right.$ and $\left.\mathrm{Cu}_{2} \mathrm{O}\right)$, are well-known 185 p-type semi-conductors with a high thermal stability and chemical reduction potential (Isherwood, 186 2017). Positive surface charge, optical properties at visible wavelength, and the high surface area 187 of $\mathrm{Cu}$ NPs are the beneficial properties for degradation, reduction, and adsorption of inorganic and 
organic contaminants (Khalaj et al., 2018) (Supplementary Information: Table S2). For example, $\mathrm{CuO}$ NPs synthesized via a sol-gel procedure was used for $\mathrm{Cd}^{2+}$ and $\mathrm{Ni}^{2+}$ removal from aqueous solution, wherein high $\mathrm{pH}$ of the aqueous medium generated surface negative charge on the adsorbent, and stimulated metal adsorption by electrostatic attraction (Hassan et al., 2017). Zero valent $\mathrm{Cu}$ NPs $\left(\mathrm{Cu}^{0}\right)($ dose $=2 \mathrm{~g} / \mathrm{L}, \mathrm{pH}=7.0)$ degraded 2,4-dichlorophenol $(7.5 \mathrm{mg} / \mathrm{L})$ to the tune of $60 \%$ within 5 days of reaction (Chang et al., 2019). Nutrients removal (N, P) from activated sludge using $\mathrm{Cu}$-based NPs were investigated where phosphate removal capacity reached $98 \%$, and $\mathrm{N}$ removal reached $\sim 73 \%$ at a $5 \mathrm{mg} / \mathrm{L}$ dosage of NPs (Chen et al., 2012). CuO NPs also degraded nitrobenzene in aqueous solution upon sonication for $25 \mathrm{~min}$ via a Fenton reaction $(\cdot \mathrm{OH}$ radicals) (ElShafei et al., 2014). Furthermore, green synthesized Cu-based NPs using Punica granatum leaf extracts improved the functionality of nanoparticles for removing methylene blue (MB) from aqueous solution through electrostatic attraction, with an adsorption capacity of $166 \mathrm{mg} / \mathrm{g} \mathrm{MB}$ (Vidovix et al., 2019). However, the increasing application of $\mathrm{Cu}$-based NPs raised concerns of negative environmental impacts to living organisms (Chen et al., 2012). The phytotoxicity of $\mathrm{Cu}$ NPs on wheat (Perreault et al., 2014), the cytotoxicity of the NPs on human epithelial cells (Moschini et al., 2013), NP-caused growth inhibitions, the Cu uptake of Arabidopsis thaliana upon application of $\mathrm{Cu}$ NPs (Wang et al., 2016), and their toxic effects on aquatic organisms such as Hydra magnipapillata have been reported (Murugadas et al., 2016). Therefore, it is prudent to synthesize encapsulated or supported Cu NPs, which have low toxicity toward organisms while retaining a high contaminant removal capability.

\subsection{Bimetallic nanoparticles (BNPs)}


BNPs contain two metallic elements, exhibiting properties related to each metal and resulting from synergistic interactions between two metals. The assembly of BNPs can be as random

212 alloys, alloys with an intermetallic compound, cluster-in-cluster or core-shell structures (Zaleska213 Medynska et al., 2016). The shape and size of metallic NPs are strictly dependent on their mode 214 of preparation that also influences the physicochemical properties of the final product (Zaleska215 Medynska et al., 2016). Preparation methods for the production of BNPs include chemical 216 reduction, green synthesis, microemulsion method, photodeposition, and radiolysis (Zaleska217 Medynska et al., 2016).

218 BNPs can remediate multiple contaminants in aqueous systems (Scaria et al., 2020). A Fe ${ }_{0.9} / \mathrm{Cu}_{0.1}$ 219 BNP removed As(V) $(60.22 \mathrm{mg} / \mathrm{g})$ from aqueous solution (initial As(V) concentration = 200 220 $\mathrm{mg} / \mathrm{L}$; adsorbent dose $=2.5 \mathrm{~g} / \mathrm{L})$ (Sepúlveda et al., 2018). Incorporation of relatively low 221 amounts of $\mathrm{Cu}$ in the $\mathrm{Fe} / \mathrm{Cu} \mathrm{BNP}$ resulted in a non-uniform core-shell structure with 222 agglomerate-type chains of magnetite that enhanced electron transfers among the metals $(\mathrm{Fe} / \mathrm{Cu})$ 223 and the target metalloid (As); hence, the adsorption of As(V) increased (Sepúlveda et al., 2018). 224 To decontaminate Se(IV) in groundwater, Fe-Mn binary oxide NPs were synthesized and 225 stabilized with starch and carboxy methyl cellulose (CMC) (Xie et al., 2015). The starch226 stabilized NPs were more effective than CMC stabilized NPs in adsorbing Se(IV), with 227 maximum adsorption capacities of 109 and $95 \mathrm{mg} \mathrm{Se} / \mathrm{g}$ for the starch- and CMC-stabilized NPs 228 (Xie et al., 2015).

229 Ascorbic acid-stabilized Fe/Pd BNPs and silica-based Fe and Fe/Fe-oxide NPs were successfully 230 tested for degrading trichloroethylene in water (Meeks et al., 2012). Due to high catalytic activity 231 of BNPs, Fe/Ni-polystyrene cation exchange resin composites showed nearly $91 \%$ degradation 232 and/or dechlorination of trichloroethylene (20 mg/L initial concentration) (Zhou et al., 2016). 
233 Similarly, biochar-supported Ni/Fe BNPs also enhanced the reduction of 1,1,1-trichloroethane 234 (1,1,1-TCA) in groundwater remediation ( $\mathrm{Li}$ et al., 2017). The 1,1,1-TCA removal efficiency 235 increased up to $99.3 \%$ when the $\mathrm{BC}$ to $\mathrm{Ni} / \mathrm{Fe}$ mass ratio reached 1.0 (Li et al., 2017).

\subsection{Other metal oxide nanoparticles}

238 The oxides of $\mathrm{Ti}, \mathrm{Mg}$, and $\mathrm{Zn}$ have proven useful for removing contaminants from the 239 environment although the application of metal oxide nanoparticles can influence mineral 240 nutrition, oxidative stress and photosynthesis of plants (Rizwan et al., 2017). Some nanoparticles synthesized with the mediation of plants and/or plant products (e.g., Au NPs from Cassia fistula,

242 FeO from Rumex acetosa) have been reported to be beneficial in environmental, agricultural and

243 biomedical applications (Rai et al., 2018). $\mathrm{TiO}_{2} \mathrm{NPs}$ displayed a high photocatalytic degradation 244 efficiency of $90.24 \%$ at a $20 \mathrm{mg} / \mathrm{L}$ initial concentration and $\mathrm{pH} 5.0$ for imidacloprid in an 245 aqueous system (Akbari Shorgoli \& Shokri, 2017). The catalytic activity of flower-like 246 nanostructured rutile $\left(\mathrm{TiO}_{2}\right)$ was used to rapidly degrade methyl orange (MO) and inactivate 247 drug-resistant bacteria such as Klebsiella pneumonia (Körösi et al., 2016). Similarly, 248 photodegradation of levofloxacin by ternary nano $\mathrm{Ag}_{2} \mathrm{CO}_{3} / \mathrm{CeO}_{2} / \mathrm{AgBr}$ photocatalysts under 249 visible-light irradiation was investigated and a double Z-scheme photocatalytic mechanism was 250 proposed, which involved an electron transfer process by the active participation of radicals such $251 \mathrm{as} \mathrm{h}^{+}, \mathrm{O}_{2}{ }^{-}$and $\cdot \mathrm{OH}$ in the photodegradation (Wen et al., 2018). Naphthalene was effectively 252 removed (148.3 mg/g) from wastewater using ZnO NPs modified with 1-butyl-3253 methylimidazolium tetrafluoroborate, and the removal capacity of the modified adsorbent was $254122 \%$ higher than the bare ZnO NPs (Kaur et al., 2017). In spite of their capacity to remove a 
255 wide range of contaminants, metal oxide NPs may cause ecotoxicological effects towards

256 various organisms. Therefore, care should be taken in terms of dosage during their application.

\subsection{Carbon nanotubes}

259 Single and multi-walled CNTs (SWCNTs and MWCNTs) are widely used as adsorbents for 260 wastewater purification. The rolling of a single graphene layer into a cylindrical shape creates a

261 SWCNT, while the rolling of many concentric SWCNTs into a tubular shape creates an

262 MWCNT (Gusain et al., 2020). The removal of contaminants through adsorption is more rapid

263 for CNTs than other carbonaceous adsorbents (activated carbon, graphene, graphene oxides, and

264 biochar) due to availability of reactive adsorption sites and short diffusion distance (Lee et al.,

265 2018). The major surface functional groups (e.g., $-\mathrm{COOH}$ and $-\mathrm{OH}$ ) of CNTs participate in the

266 bulk adsorption of contaminants. Studies have been conducted to graft other functional groups

267 (e.g., $-\mathrm{NH}_{2}$ and $-\mathrm{SH}$ ) onto the surface of CNTs to enhance the adsorption capacities

268 (Supplementary Information: Table S3). The adsorption affinity of CNTs can be increased by

269 functionalizing the surfaces of CNTs through various processes such as oxidation, nonmagnetic

270 metal oxide coating and grafting of magnetic iron oxides (Sarkar et al., 2018). The mechanisms

271 involved in the adsorption process of contaminants by CNTs are dependent on the surface

272 properties of CNTs and the chemistry of the contaminant ions or compounds. The mechanisms

273 may include chemisorption or physisorption, while the ionic radius and hydration energy of the

274 contaminants are important factors that determine the adsorption mechanisms (Sarkar et al.,

275 2018).

276 The most prominent application of CNTs in environmental remediation includes the removal of

277 organic contaminants through membrane filtration due to the high stability and large specific 
278 surface area of CNTs (Jame \& Zhou, 2016). An electrochemically activated CNT filter was able

279 to generate $\mathrm{OH}^{-}$radicals from $\mathrm{H}_{2} \mathrm{O}_{2}$ to remove phenol from aqueous solution to the tune of $87 \%$ 280 within $4 \mathrm{~h}$ (Liu et al., 2015). CNTs also show catalytic activity to clean wastewater due to their 281 cylindrical hollow tubes, high mechanical strength, and electrochemical properties. Ruthenium

$282(\mathrm{Ru})$ precursor impregnated MWCNTs converted $100 \%$ aniline in wastewater within 45 min of 283 reaction time (Garcia et al., 2006). However, the catalytic activity of CNTs is limited due to their 284 hydrophobic nature, and the presence of impurities (Lee et al., 2018). Another prominent 285 application of CNTs is in sensor-based approaches for contaminant detection. A selective sensor 286 for $\mathrm{Hg}(\mathrm{II})$ was developed by adsorbing cold mercury vapor on SWCNTs in industrial wastewater 287 (Safavi et al., 2010). The sensor was able to sense as low as $0.64 \mu \mathrm{g} / \mathrm{mL} \mathrm{Hg}$ (II) in various types 288 of wastewater samples (Safavi et al., 2010). Future research should be focused on the application 289 of CNTs for real water decontamination using membrane filtration, catalysis, and sensing 290 approaches while also concentrating on the ecotoxicity assessment of CNTs.

\section{$292 \quad 2.6 \quad$ Graphene and graphene oxide}

293 Graphene is a 2D structured material having a single atomic layer of $\mathrm{sp}^{2}$ bonded carbon atoms, 294 with each atom bonded to 3 others in a hexagonal lattice. Graphene shows high strength, 295 durability and specific surface area (Meyer et al., 2007). Graphene oxide (GO) has a structure 296 similar to that of graphene, while having more oxygen containing functional groups (Ma et al., 297 2017). The presence of hydrophobic moieties and $\pi-\pi$ interactions in GO lead to high removal 298 efficiencies for aromatic pollutants (Ersan et al., 2017). Oxygen-containing surface functional 299 groups $(-\mathrm{COOH},-\mathrm{OH}$ and $-\mathrm{C}=\mathrm{O})$ may also be present in $\mathrm{GO}$ due to the incomplete reduction of 300 GO. Another oxidized form of GO is exfoliated graphene oxide (EGO), which contains various 
301 surface functional groups such as hydroxyl, carboxyl, and epoxy groups (Ramesha et al., 2011).

302 The advantages of graphene oxides for water treatment are their colloidal stability and high

303 dispersibility in water, while graphene-based nanocomposites (modified with organic molecules

304 and magnetic graphene nanocomposites) show higher specific surface areas and improved

305 functionality than unmodified graphene (Perreault et al., 2015). In addition, reduced GO (rGO)

306 shows high electron transport capacity and increased interaction with metal contaminants

307 (Gollavelli et al., 2013; Lin et al., 2019). The adsorption of dyes such as MB, methyl violet, and

308 rhodamine $\mathrm{B}$ onto EGO and reduced $\mathrm{GO}(\mathrm{rGO})$ sheets has been widely studied in water

309 (Supplementary Information: Table S4). The elevated negative charge density assists in the

310 effective adsorption of cationic dyes on EGO. In contrast, rGO, which has a high surface area, is

311 effective in anionic dye adsorption due to van der Waals interactions (Ramesha et al., 2011).

312 The prevalence of surface charges and different functional groups on EGO, GO, and rGO play

313 important roles in the adsorption of polar contaminants such as phenolics and naphthol, charged

314 heavy metals (Ahmad et al., 2020; Ersan et al., 2017), antibiotics such as sulfamethoxazole,

315 sulfapyridine, and sulfathiazole (Çalışkan Salihi et al., 2020), and volatile organic compounds

316 (Kumar et al., 2020b). The adsorption of phenolic compounds generally increases with

317 increasing reduction degree in $\mathrm{GO}$, whereas the adsorption of heavy metal ions shows the reverse

318 trend (Wang \& Chen, 2015). Likewise, Cd(II) and organic pollutants were co-adsorbed onto

319 graphene via surface-bridging mechanisms (Wang \& Chen, 2015). The adsorption affinity of

320 four aromatics on GO increased in the following order: naphthalene (NAPH) $<1,2,4-$

321 trichlorobenzene (TCB) < 2,4,6-trichlorophenol (TCP) < 2-naphthol (Pei et al., 2013). The $\pi-\pi$

322 interaction was the main mechanism involved during TCB, TCP and 2-naphthol adsorption onto

323 graphene (Zhou et al., 2015), whereas H-bonding and O-containing surface functional groups 
324 were responsible for the adsorption of TCP and 2-naphthol onto GO (Pei et al., 2013). However,

325 graphene-based NMs often suffer from low densities of reactive sites, including less oxygen-

326 containing functional groups, while graphene-based nanocomposites show variable colloidal

327 stability depending on modification type (Perreault et al., 2015). Future research should focus on

328 the development of highly functionalized and stable graphene-based NMs for bulk removal of

329 contaminants from aqueous solutions.

330

\section{$331 \quad 2.7 \quad$ Polymer nanoparticles}

332 The synthesis of polymer NPs follows two approaches: top-down and bottom-up (Krishnaswamy

$333 \&$ Orsat, 2017). The top-down approach involves the dispersion of preformed polymers to

334 produce polymer nanoparticles, while the bottom-up approach involves the polymerization of

335 monomers to produce polymeric nanoparticles. Following the bottom-up approach, researchers

336 synthesized hybrid polymer NPs from the ring-opening polymerization of pyromellitic acid

337 dianhydride and phenylaminomethyl trimethoxysilane, followed by a sol-gel process to remove

338 heavy metals such as $\mathrm{Cu}(\mathrm{II})$ and $\mathrm{Pb}(\mathrm{II})$ from water (Liu et al., 2010). These zwitterionic hybrid

339 polymers adsorbed 0.28 and $1.56 \mathrm{mmol} / \mathrm{g}$ of $\mathrm{Cu}(\mathrm{II})$ and $\mathrm{Pb}(\mathrm{II})$, respectively, via electrostatic

340 attraction when the initial metal concentrations were in the range of 0.001 to $0.1 \mathrm{~mol} / \mathrm{L}$, and the

341 dose of adsorbent was $1 \mathrm{~g} / \mathrm{L}$ (Liu et al., 2010). The development of a negative charge on the

342 hybrid polymer NPs was mainly due to - $\mathrm{COOH}$ groups in the polymer hybrid which

343 deprotonated to $-\mathrm{COO}^{-}$groups in aqueous system at $\mathrm{pH}>4.0$ and 5.0 during $\mathrm{Cu}(\mathrm{II})$ and $\mathrm{Pb}(\mathrm{II})$

344 adsorption, respectively, and was thus bound to positively charged metal ions on the NP surfaces

345 (Liu et al., 2010). 
MO was removed in an aqueous solution using polyamine nanoadsorbents. The MO adsorption capacity was increased by 32.04 and $30.28 \mathrm{mg} / \mathrm{g}$, respectively, when the initial dye concentrations were increased from 10 to $100 \mathrm{mg} / \mathrm{L}$ at $65^{\circ} \mathrm{C}$ and $25^{\circ} \mathrm{C}$, respectively. The MO adsorption was endothermic in nature, and the maximum $\mathrm{MO}$ adsorption capacity was $75.9 \mathrm{mg} / \mathrm{g}$ within 60 min of reaction time when $\mathrm{pH}$ of the medium was 6-10. Strong electrostatic attraction was the primary mechanism that caused maximum MO adsorption (Tanzifi et al., 2017).

352 Chitosan, a biopolymer, is widely used to synthesize NPs for environmental remediation due to 353 its low toxicity and high biodegradability. In a recent study, chitosan NPs were synthesized 354 through ionotropic gelation for encapsulating enzymatic activity (Alarcón-Payán et al., 2017). The chitosan-NPs were loaded with versatile peroxidases and were successful in the

356 biodegradation of phenolic compounds. The chitosan-based enzymatic NPs had a higher affinity 357 constant toward phenolic compounds, were more thermostable than free enzymes, and their 358 operational stability was further enhanced in a real-world wastewater situation when modified 359 with different aldehydes (Alarcón-Payán et al., 2017). Similarly, chitosan NPs prepared through ionotropic gelation between chitosan and tripolyphosphates showed a 98\% Congo red (CR) removal efficiency and adsorbed 5,107 $\mathrm{mg} \mathrm{CR/g}$ of adsorbent in an aqueous solution (Alver et

362 al., 2017). CR removal was dependent on the $\mathrm{pH}$, ionic strength, encapsulation time and 363 tripolyphosphate concentration. The mechanism involved was a strong electrostatic attraction 364 between the protonated amino groups, with anionic CR at low pH (Alver et al., 2017). However, 365 chitosan suffers from poor solubility in water (soluble in acid) and stability, which restrict its 366 applicability in a wide range of contaminant removal applications (Saheed et al., 2020). Future 367 research should be carried out in order to remove these barriers by using novel modifications. 368 


\subsection{Nanomaterials supported on inert materials and polymers}

370 Environmental applications of NMs supported on inert materials (bulky, stable and non-toxic to

371 organisms) such as activated carbon, BC, clay minerals, biodegradable polymers, and zeolites

372 have recently attracted widespread attention (Mandal et al., 2018). Their availability, low-cost,

373 and less toxic nature made these support materials popular in the field of soil and water

374 remediation (Krasucka et al., 2021; Lazaratou et al., 2020). Pristine clay minerals, zeolites, and

375 biochar often suffer from low contaminant adsorption and poor regeneration capacity, which can

376 be improved by supporting NMs (e.g., nZVI) on the former materials leading to improved

377 functionality and dispersion of the NMs (Mukhopadhyay et al., 2020; Premarathna et al., 2019;

378 Alam et al., 2020) For example, granular activated carbon (GAC) was used to impregnate NPs

379 (e.g., nZVI), and the supported material subsequently removed nitrobenzene from water (Mines

380 et al., 2018). Reduction of nitrobenzene (with an initial concentration of $500 \mu \mathrm{M}$ ) was achieved

381 at up to $56.6 \%$ by GAC-nZVI, which further improved to $63.6 \%$ following an additional

382 modification step of the material with a covalent organic polymer (Mines et al., 2018). The $\pi-\pi$

383 interaction between the aromatic groups of covalent organic polymer materials and nitrobenzene

384 likely facilitated the removal of the contaminant (Mines et al., 2018).

385 Clay minerals were used extensively to support NMs for environmental remediation applications.

386 For instance, a cationic surfactant cetyltrimethylammonium bromide (CTMAB) was used to

387 improve the hydrophobic property of Fe-NPs supported on palygoskite clay, and the

388 nanocomposite removed acid orange 7 (AO-7) by $98.4 \%$ (initial concentration of $20 \mathrm{mg} / \mathrm{L}$ )

389 within $2 \mathrm{~h}$ of reaction from aqueous solution. At low $\mathrm{pH}$, dissolved oxygen in the solution

390 enabled hydrogen ions to produce $\mathrm{H}_{2} \mathrm{O}_{2}$ and ${ }^{\circ} \mathrm{OH}$ radicals, which provided more oxidants to

391 degrade AO-7 (Quan et al., 2018). Palygorskite-carbon nanocomposites were prepared through 
392 two methods: composite 1 involved a hydrothermal carbonization with starch on palygorskite,

393 while composite 2 included a thermal activation $\left(550^{\circ} \mathrm{C}\right.$ for $3 \mathrm{~h}$ in a $\mathrm{CO}_{2}$ environment $)$ of

394 composite 1 (Sarkar et al., 2015). Composite 2 adsorbed a large amount of anionic orange II dye

$395(23.0 \mathrm{mg} / \mathrm{g})$, whereas composite 1 efficiently adsorbed cationic MB (46.3 mg/g) (Sarkar et al.,

396 2015). Similarly, a nanocomposite synthesized in-situ by embedding magnetite NPs into the

397 palygorskite structure through the co-precipitation method had a maximum $\mathrm{Pb}(\mathrm{II})$ adsorption

398 capacity of $26.6 \mathrm{mg} / \mathrm{g}$ (Rusmin et al., 2017).

399 nZVI can aggregate in aqueous solution when its concentration is high. Therefore, to avoid rapid 400 aggregation and to improve its reactivity, zeolite supported nZVI (Z-nZVI) was prepared via the 401 liquid phase reduction of Fe(III) salts (Suazo-Hernández et al., 2019). The maximum adsorption 402 capacity of Z-nZVI was $11.52 \mathrm{mg} \mathrm{As(III)/g,} 48.63 \mathrm{mg} \mathrm{Cd}(\mathrm{II}) / \mathrm{g}$, and $85.37 \mathrm{mg} \mathrm{Pb}(\mathrm{II}) / \mathrm{g}$ at $\mathrm{pH}$, 403 involving mechanisms such as electrostatic attraction, ion exchange, oxidation, reduction, co404 precipitation, and complexation depending upon the ionic nature of heavy metal(loid)s (Li et al., 405 2018). nZVI supported on CTMAB-modified organobentonite was used as a reducing agent for 406 organic contaminants such as 2-chlorophenol(2-CP), 2,4-dichlorophenol (2,4-DCP), 2,4,6-

407 trichlorophenol (2,4,6-TCP) and pentachlorophenol (PCP) in an aqueous system; their removal 408 efficiencies were 95.4, 96.8, 97.8, and 100\%, respectively (Li et al., 2013).

409 Similar to clay minerals, biochar is another inert material used widely for supporting NMs (Liu 410 et al., 2020). A novel GO-coated BC nanocomposite achieved a 30\% enhancement in 411 sulfamethazine sorption through $\pi-\pi$ interactions between the antibiotic molecules and NPs 412 (Huang et al., 2017). A ZVI-BC-chitosan nanocomposite was also shown suitable for removing 413 heavy metals such as $\mathrm{Pb}(\mathrm{II})$ and $\mathrm{As}(\mathrm{V})$ and MB dye (Zhou et al., 2014). The novel 414 nanocomposite removed $\mathrm{Pb}(\mathrm{II}), \mathrm{As}(\mathrm{V})$ and $\mathrm{MB}$ at 93, 95 and 68\%, respectively (the initial 
concentrations of $\mathrm{Pb}(\mathrm{II}), \mathrm{As}(\mathrm{V})$ and $\mathrm{MB}$ were 40, 21 and $20 \mathrm{mg} / \mathrm{L}$, respectively) (Zhou et al., 2014). The $\mathrm{Cr}(\mathrm{VI})$ removal in an aqueous system was also achieved by using nZVI assisted BC composites where the adsorbent showed $58.82 \mathrm{mg} / \mathrm{g} \mathrm{Cr}(\mathrm{VI})$ removal via electrostatic attraction, complexation, metal reduction, and precipitation reactions (Zhu et al., 2018). The nZVI/biochar composite can play a dual role, firstly by converting the contaminant into a less toxic form by nZVI, and then adsorbing the contaminant via the active surface functional groups present on biochar, involving electron donor-acceptor reactions, chemisorption, and electrostatic attraction mechanisms (Fig. 3).

Attempts were made to stabilize CNTs on BC to remove heavy metals from wastewater (Inyang et al., 2015). $\mathrm{Pb}$ (II) was removed from wastewater using multi-walled CNTs dispersed on BC hickory chips (pyrolysis at $600^{\circ} \mathrm{C}$ in $\mathrm{N}_{2}$ environment for $1 \mathrm{~h}$ ), and the nanocomposite adsorbed $31.05 \mathrm{mg} \mathrm{Pb}(\mathrm{II}) / \mathrm{g}$ (initial concentration of $40 \mathrm{mg} / \mathrm{L}$ ) (Inyang et al., 2015). The authors (Inyang et al., 2015) also found that bagasse BC modified with sodium dodecylbenzenesulfonate-CNTs (prepared using the same conditions above) was successful in fixing sulfapyridine by $56 \%$ (the initial concentration was $20 \mathrm{mg} / \mathrm{L}$, solid: solution $=2: 1$, reaction time $24 \mathrm{~h}$ ) in wastewater. Chitosan-based composite NMs were also successful in removing heavy metals. The efficiency of alginate-coated chitosan NPs (Alg-CS-NPs) in removing Ni(II) from industrial effluents was investigated (Esmaeili \& Khoshnevisan, 2016), showing that nearly 95\% of $\mathrm{Ni}(\mathrm{II})$ was removed from solution under the following conditions: $\mathrm{pH}=3$, initial $\mathrm{Ni}(\mathrm{II})$ concentration $=70 \mathrm{mg} / \mathrm{L}$, adsorbent dose $=0.3 \mathrm{~g}$, and contact time $=30 \mathrm{~min}$ (Esmaeili \& Khoshnevisan, 2016). At pH 3.0, the formation of sparingly soluble hydroxides of metals occurred, which contributed to overall metal removal from solution. At a high initial $\mathrm{Ni}(\mathrm{II})$ concentration $(70 \mathrm{mg} / \mathrm{L})$, the competitive adsorption of $\mathrm{Ni}(\mathrm{II})$ on the outer surface of the NPs led to a high adsorption capacity, whereas a 
438 high biomass dose $(0.3 \mathrm{~g})$ provided an increased surface area for the $\mathrm{Ni}(\mathrm{II})$ biosorption process

439 (Esmaeili \& Khoshnevisan, 2016).

440 Like chitosan, entrapment of nZVI in Ca-alginate beads (polymer) showed promising results for

$441 \mathrm{NO}_{3}-$ removal from groundwater. Ca-alginate beads acted as a bridge to bind the nZVI particles.

442 Between 50-73\% $\mathrm{NO}_{3}-\mathrm{N}$ was removed by the alginate-entrapped $\mathrm{nZVI}$, which was statistically

443 similar to bare nZVI within the $2 \mathrm{~h}$ reaction period (Bezbaruah et al., 2009). Like $\mathrm{NO}_{3}^{-}$, TCE

444 degradation was also achieved, up to $81-90 \%$, due to encapsulation of nZVI within Ca-alginate

445 beads. The encapsulation resulted in greater mobility of nZVI particles than the entrapment

446 method, and the required amount of Ca-alginate was significantly lower than for the entrapment

447 method (Bezbaruah et al., 2011).

448 Entrapped nZVI in the alginate polymer matrix showed enhanced removal capacity of 1,1,2-

449 trichloroethane (TCA) during the treatment of hydraulic fracturing wastewater (Lei et al., 2018).

450 Results suggested that nZVI entrapment in alginate with or without polyvinyl alcohol removed

451 1,1,2-TCA from water (62.6-72.3\%) with lower Fe aggregation after 90 days. The nZVI

452 provided a chemically reducing condition, while the polymers adsorbed 1,1,2-TCA during

453 wastewater remediation. Sun et al. (2018) reported that alginate-polyvinyl entrapped nZVI, aged

454 for 2-months, showed a high removal capacity for $\mathrm{Cu}(\mathrm{II})(84.2 \%)$ and $\mathrm{Cr}(\mathrm{VI})(70.8 \%)$, much

455 higher than for freshly prepared beads. The corresponding removal efficiencies were 31.2 and

$45639.2 \%$ in case of $\mathrm{Zn}(\mathrm{II})$ and $\mathrm{As}(\mathrm{V})$, respectively. The aging effect of the adsorbent for removing

457 heavy metals was dependent on electrostatic interaction and specific bond formation mechanisms

458 (Sun et al., 2018).

459

$460 \quad 2.9 \quad$ Carbo-iron nanomaterials 
461 Carbo-iron is a composite NM consisting of nZVI clusters on activated carbon colloids (ACC)

462 with a particle size of $0.8 \mu \mathrm{m}$. The material is especially designed for the in-situ generation of 463 reactive zones and contaminant source removal when applied in groundwater remediation 464 processes (Bleyl et al., 2012; Mackenzie et al., 2012). The carbo-iron colloids (CIC) can overcome 465 the limitations of nZVI during in-situ groundwater remediation. The ACC gets reduced by $\mathrm{H}_{2}$ in 466 order to form CIC. The ACC have sorption properties, while nZVI provides strong reactivity to 467 degrade or immobilize the contaminants. For example, CIC produced $60 \%$ chlorine-free- $\mathrm{C}_{2}-$ 468 hydrocarbons when degrading TCE (Mackenzie et al., 2012). Similarly, pentachloroethane (PCE) 469 dechlorination in groundwater was achieved at field scale in Germany with NM transport lengths 470 of several metres and fast PCE decomposition without forming toxic vinyl chloride (Mackenzie et 471 al., 2016). However, the release of Carbo-iron NM (in $\mathrm{g} / \mathrm{L}$ concentration) in the environment 472 during groundwater treatment may have ecotoxicological effects on amphipod Hyalella azteca 473 leading to inhibited weight, length, and feeding rate of the animal (Weil et al., 2016). However, 474 the ecotoxicological data on Daphnia magna (Crustacea), Scenedesmus vacuolatus (Algae), 475 Chironomus riparius (Insecta), and nitrifying soil microorganisms revealed no effect at $0.1 \mathrm{mg} / \mathrm{L}$ $476 \mathrm{NM}$ concentration in acute or chronic toxicity tests in groundwater contaminated with 477 chlorohydrocarbons (Weil et al., 2019). The risks to organisms were minimized by around 50\% 478 after the first injection of Carbo-iron NM in heavily contaminated aquifer zones, which suggested 479 more benefits of remediation than detriments due to toxicity effects (Weil et al., 2019).

\subsection{Other nanomaterials}

482 NPs such as $\mathrm{NiFe}_{2} \mathrm{O}_{4}$ and zinc aluminate were reported to degrade dyes in aqueous solution. For 483 example, $77 \%$ degradation of $\mathrm{MO}$ (initial concentration of $10 \mathrm{mg} / \mathrm{L}$ ) was achieved by $\mathrm{NiFe}_{2} \mathrm{O}_{4}$ 
484 NPs within $5 \mathrm{~h}$ of exposure to sunlight, compared to no significant degradation under dark

485 conditions (Hirthna et al., 2018). The dye removal mechanism in this study followed an electron

486 paramagnetic resonance type of photodegradation (Hirthna et al., 2018). Likewise, 98.28\%

487 photodegradation of MB (initial concentration $10 \mathrm{mg} / \mathrm{L}$ ) was achieved in $150 \mathrm{~min}$ using bismuth

488 doped zinc aluminate NPs (Kirankumar \& Sumathi, 2017). Bismuth doping into zinc aluminate

489 decreased the band gap energy significantly, which in turn increased the photocatalytic

490 degradation of MB. A hybrid-nano $\mathrm{Ag}_{3} \mathrm{PO}_{4}$ composite was synthesized by a two-step

491 solvothermal process using reduced graphene oxide ( $\mathrm{rGO}$ ), $\mathrm{Ag}_{3} \mathrm{PO}_{4} \mathrm{NPs}$ and molybdenum

492 dichalcogenides $\left(\mathrm{MoS}_{2}, 99 \%\right)$; the synthesized hybrid-nano $\mathrm{Ag}_{3} \mathrm{PO}_{4}$ composite was suitable for

493 the degradation of 4-nitrophenol, with a greater photocatalytic activity and stability than pure

$494 \quad \mathrm{Ag}_{3} \mathrm{PO}_{4} \mathrm{NPs}$ (Zhang et al., 2018a).

495

\section{$496 \quad 3 . \quad$ Nanomaterials for contaminants treatment in soil}

497 Several studies have reported the immobilization of toxic metal(loids) in soils using NMs

498 (Baragaño et al., 2020; Matos et al., 2017; Tafazoli et al., 2017). However, the fates of NMs after

499 their application to soils for contaminant removal require proper understanding. Currently,

500 available soil contaminant remediation strategies follow two main directions: (i) lowering the

501 concentration of pollutants to well below a critical limit, and (ii) stabilization of pollutants within

502 the soil to reduce their immediate risk to environmental receptors (Floris et al., 2017; Hou et al.,

503 2020). There is a growing interest in NMs for soil remediation because of their large specific

504 surface area, high chemical reactivity and selectivity, although their reactivity may vary with

505 geochemical conditions. Reports are available on the use of NMs for the remediation of

506 inorganic contaminants in soil (Supplementary Information: Table S5). Recently, nZVIs have 
attracted widespread research attention in detoxifying soil due to their effectiveness in reducing or inactivating various metallic species present in soils (Jiang et al., 2018). An nZVI/Cu treatment reduced $\mathrm{Cr}(\mathrm{VI})$ by $99 \%$ at $\mathrm{pH} 5.0$ (Zhu et al., 2016), while the $\mathrm{Cr}(\mathrm{VI})$ reduction efficiency increased from 14.58 to $86.83 \%$ without maintaining $\mathrm{pH}$ of the soil (Singh et al., 2012b). In the presence of diethylenetriaminepentaacetic acid (DTPA), Cr release decreased up to $81 \%$ due to the application of $4 \%$ bentonite supported nZVI (prepared using green tea leaf extract and $\mathrm{FeSO}_{4} .7 \mathrm{H}_{2} \mathrm{O}$ ). The reduction in $\mathrm{Cr}$ release by the same material was $79 \%$ in the presence of $\mathrm{CaCl}_{2}$ in the soil. The mechanisms involved precipitation and surface complexation reactions on the bentonite-nZVI (Soliemanzadeh \& Fekri, 2017).

The bioavailability of single and multi-metal(loid)s (As, $\mathrm{Cd}, \mathrm{Cr}, \mathrm{Pb}$, and $\mathrm{Zn}$ ) in contaminated soils in the presence of nZVI was assessed under acidic and calcareous soils. The availability of heavy metals and metalloids such as $\mathrm{As}, \mathrm{Cr}$ and $\mathrm{Pb}$ was reduced by $82 \%$ upon an application of $10 \% \mathrm{nZVI}(\mathrm{w} / \mathrm{w})$, whereas the corresponding values for $\mathrm{Zn}$ and $\mathrm{Cd}$ varied from 31 to $75 \%$ and 13 to $42 \%$ (Gil-Díaz et al., 2017b). Furthermore, the stability and effectiveness of nZVIs were confirmed in contaminated soils $(\mathrm{Cd}, \mathrm{Cr}$, and $\mathrm{Zn})$ grown with barley plants. A $10 \%$ dose of nZVI enhanced the development of the barley plants and decreased the As uptake by decreasing the bioavailable As fraction (Gil-Díaz et al., 2016a; Gil-Díaz et al., 2016b). A nZVI/Ni BNPs prepared using $\mathrm{NaBH}_{4}$ were applied to remediate $\mathrm{Cr}(\mathrm{VI})$ contaminated soils, and the reduction of $\mathrm{Cr}(\mathrm{VI})$ in the soil leachate reached as high as $99.84 \%$ at $\mathrm{pH} 5.0$ (Zhu et al., 2017a).

Three commercial nZVI slurries from Toda (bare RNIP and RNIP-D; D denotes an organic dispersant) and from Nano Iron (25S) were used at different doses (1, 5 and 10\%) to immobilize As and $\mathrm{Hg}$ in soils. A 5\% application of nZVI showed a decreasing trend of exchangeable As (by $>70 \%$ ) in soil, whereas a $10 \%$ application of nZVI was necessary to achieve a reduction of 
530 exchangeable-Hg between 63 and 90\% depending on the nZVI and soil types. Overall, the 5\%

531

532

533

534

535

536

537

538

539

540

541

542

543 along with soil $\mathrm{pH}$.

544 The immobilization and degradation of organic contaminants by NMs in soil is sporadically

545 studied. The removal efficiency of hexachlorobenzene by nZVI was investigated in the presence

546 of competing or coexisting anions present in the soil (Su et al., 2012). $\mathrm{HCO}_{3}{ }^{-}$had no effect on the

547 decomposition of hexachlorobenzene, but $\mathrm{Cl}^{-}$and $\mathrm{SO}_{4}{ }^{2-}$ promoted rapid decomposition rates,

548 while $\mathrm{NO}_{3}{ }^{-}$competed with the contaminant molecules ( $\mathrm{Su}$ et al., 2012). p, $p^{\prime}$-DDT degradation

549 using nZVI-B (prepared using the sodium borohydride method) and nZVI-T (commercially

550 purchased) in soil showed a low rate of DDT degradation (22.4 and 9.2\%) due to the presence of

551 organic matter and other soil constituents (El-Temsah et al., 2016). Han et al. (2016) reported

552 degradation half-lives of $37.5,73.7$ and $24.1 \mathrm{~h}$ for DDT in flooded soil at $35^{\circ} \mathrm{C}$ by $\mathrm{nZVI}$, nZVI 
553 coated with polyimide, and nZVI coated with sodium oleate, respectively. Similarly, the positive 554 effect of Ni/Fe BNPs in reducing the phytotoxicity of polybrominated diphenyl ethers (PBDEs)555 contaminated soil to Chinese cabbage was evaluated (Wu et al., 2016a). The germination rate, 556 and shoot and root lengths of the Chinese cabbage in the Ni/Fe BNPs treated soil increased by 557 nearly 15, 60, and 63\%, respectively, compared to the control (Wu et al., 2016a).

558 Biochar supported nanoparticles have shown promise in heavy metal immobilization in soils, as 559 they provide additional active sites for capturing metal ions (Zhu et al., 2017b). Biochar560 supported nano iron phosphate particles were synthesized to remediate Cd(II) contaminated soil. 561 The Cd(II) immobilization efficiency of the adsorbent was $81.3 \%$ after 28 days, and Cd(II) 562 bioaccessibility (physiological-based extraction test) was reduced by $80.0 \%$. Plant growth 563 experiments proved that the composite inhibited the $\mathrm{Cd}(\mathrm{II})$ uptake to the below-ground and 564 above-ground parts of cabbage mustard by $44.8 \%$ and 70.2\%, respectively (Qiao et al., 2017). 565 Application of BC-supported nano hydroxyapatite reduced $\mathrm{Pb}$ by $56.8 \%$ after 28 days of 566 application in a Pb-contaminated soil (Yang et al., 2016b), and a column experiment showed 567 significant mobility of $\mathrm{BC}$-supported nano hydroxyapatite. The immobilization rate of $\mathrm{Pb}$ in the 568 soil was $74.8 \%$ after nano hydroxyapatite-biochar remediation (Yang et al., 2016a).

569 Heavy metals such as $\mathrm{Pb}, \mathrm{Cu}$, and $\mathrm{Zn}$ were also immobilized by calcium phosphate nanoparticles 570 (CPNs) in shooting range soils. Application of these NPs to the soil decreased $\mathrm{Pb}$ and $\mathrm{Cu}$ 571 concentrations by more than $90 \%$, and $\mathrm{Zn}$ by $50 \%$ (Arenas-Lago et al., 2016). Other examples 572 include nano-hydroxyapatite, which reduced $\mathrm{Pb}(\mathrm{II})$ concentrations in Ryegrass by $2.86-21.1 \%$ 573 and $13.19-20.3 \%$ in the roots and shoots, respectively, due to the secretion of tartaric acid in the 574 root rhizosphere that enhanced $\mathrm{Pb}$ adsorption onto the NPs (Ding et al., 2017). 
575 BNPs and carbonaceous NMs have also been used for soil remediation. For example, CMC-

576 stabilized $\mathrm{Pd} / \mathrm{Fe}^{0}$ BNPs displayed a nearly 7-fold greater efficiency for $\gamma$ - hexachlorocyclohexane

577 degradation in soil as compared to $\mathrm{Fe}^{0} \mathrm{NPs}\left(\mathrm{nFe}^{0}\right)$ alone (Singh et al., 2012a). Similarly, biochar-

578 supported Ni/Fe BNPs debrominated decabromodiphenyl ether at 30.2 and $69.0 \%$ higher rates

579 than pristine Ni/Fe and biochar in soil, respectively (Wu et al., 2016b). Similarly, GO was used

580 to remediate Cd-contaminated soils; results suggested that GO could adsorb up to $103.3 \mathrm{mg} / \mathrm{g}$

581 Cd(II) when applied at a high dose $(1 \mathrm{~g} / \mathrm{kg})$, and could be used for remediating highly

582 contaminated sites (Xiong et al., 2018a).

583

$584 \quad 4 . \quad$ Approaches for contaminant nanoremediation

585 Nanoremediation involves various technical approaches such as adsorption, photodegradation,

586 heterogeneous catalysis, the involvement of microorganisms (nano-bioremediation), and

587 deployment of electrical fields (electro-nanoremediation) for applying NMs to remove or

588 immobilize contaminants in the environment. Hence, it is important to understand how the above

589 approaches work while employing NMs for remediation.

590

\section{$591 \quad 4.1 \quad$ Adsorption}

592 Adsorption of contaminants occurs on the surface of an adsorbent at the solid-liquid interface

593 (Fig. 4). The solid surface of the adsorbent interacts with the adsorbate/solute in the solution, and

594 they are attracted to each other by solid-liquid intermolecular forces (Sadegh et al., 2017). In the

595 case of bulk adsorbents, various bond (e.g., ionic, covalent and metallic) requirements of the

596 constituent atoms in the adsorbent are filled by other atoms in the material. Since the bonds of

597 atoms at the surface of the adsorbents are not fully satisfied, they adsorb the adsorbate to achieve 
598 a charge/bond balance. However, the nature of adsorption is highly dependent on the nature of

599 the adsorbate species present in the liquid solution. Adsorption processes mainly include van der

600 Waal's forces, electrostatic attraction, and chemisorption (covalent bonding) (Gupta et al., 2016;

601 Sadegh et al., 2017; Sadegh et al., 2016). In addition, adsorption also involves a mass transfer

602 process in which a solute mass is transferred to the surface of a solid and bound by

603 chemisorption or physical adsorption. High specific surface area of an adsorbent can

604 considerably control the degree of adsorbate deposition onto the adsorbent (Sadegh et al., 2017).

605

606

\subsection{Photodegradation}

607 Photocatalysis has been one of the most successful processes to remove contaminants from the

608 environment due to its low cost and environmental compatibility (Al-Mamun et al., 2019;

609 Raizada et al., 2019). Photocatalysis is a photoreaction that can be enhanced in the presence of a

610 catalyst (Fig. 5). During photocatalytic activity, electron-hole pairs are generated depending

611 upon the type of catalyst. These electron-hole pairs also generate the superoxide radicals that

612 degrade contaminants. $\mathrm{TiO}_{2}$ NPs were used as catalysts for practical applications. A novel nano-

$613 \mathrm{TiO}_{2}$ photocatalyst doped with neodymium $\left(\mathrm{Nd}^{3+}\right)$ was employed to remove $\mathrm{Cr}(\mathrm{VI})$ by catalytic

614 reduction, obtaining a $>99 \%$ efficiency in $\mathrm{Cr}(\mathrm{VI})$ reduction. Here, $\mathrm{Nd}^{3+}$ ions deposited on the

$615 \mathrm{TiO}_{2}$ surfaces facilitated the creation of sites for electron accumulation, and hence achieved a

616 high $\mathrm{Cr}(\mathrm{VI})$ reduction rate (Rengaraj et al., 2007). However, $\mathrm{TiO}_{2}$ promotes photodegradation

617 primarily under UV-light, while other catalysts such as $\mathrm{CeO}_{2}$ show rapid photodegradation rates

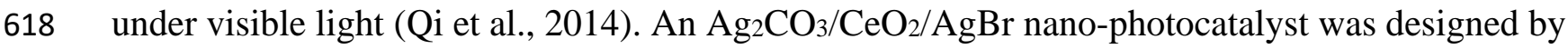

619 the in-situ loading of $\mathrm{Ag}_{2} \mathrm{CO}_{3}$ onto $\mathrm{CeO}_{2}$ spindles via the corrosion process, and the material

620 showed visible light degradation of levofloxacin (Wen et al., 2018). Various carbon-based 
621 nanomaterials such as graphene composites containing NPs (e.g., $\mathrm{TiO}_{2} \mathrm{NPs}$ ) showed enhanced

622 photocatalytic activity. Under UV irradiation, the energy of photons was greater than the band

623 gap of carbon materials, which generated valence band holes $\left(\mathrm{h}^{+}\right)$and band electrons $\left(\mathrm{e}^{-}\right)$. The

624 holes produced superoxide radicals that degraded the organic contaminants, while electrons from

625 superoxide radicals reduced heavy metal contaminants (Raizada et al., 2019).

626 Likewise, the $\mathrm{rGO} / \mathrm{MS}_{2}\left(\mathrm{M}=\mathrm{M}_{0}, \mathrm{~W}\right)$ hybrid-nano $\mathrm{Ag}_{3} \mathrm{PO}_{4}$ composite was more suitable for a 627 photocatalytic degradation of 4-nitrophenol than was pure $\mathrm{Ag}_{3} \mathrm{PO}_{4}$ (Zhang et al., 2018a). The $628 \mathrm{Ag}_{3} \mathrm{PO}_{4} @ \mathrm{MS}_{2} / \mathrm{rGO}$ composite photo-catalyst displayed a $>98 \%$ degradation efficiency for 4629 nitrophenol after four cycles of use. The $\mathrm{MS}_{2} / \mathrm{rGO}$ hybrid strongly enhanced the photocatalytic 630 stability of $\mathrm{Ag}_{3} \mathrm{PO}_{4}$ due to the reduction of $\mathrm{Ag}_{3} \mathrm{PO}_{4}$ to $\mathrm{Ag}^{0}$ by photo-generated electrons (Zhang 631 et al., 2018a). Khairy and Zakaria (2014) reported photocatalytic degradation of MO by $\mathrm{Cu}-$ 632 doped $\mathrm{TiO}_{2}$ NPs under both UV and visible light. Doping of metals (e.g., $\mathrm{Cu}$ ) did not change the 633 structure of the crystal, but a significant change was observed in the particle size and 634 photodegradation rate. $\mathrm{Cu}$-doped $\mathrm{TiO}_{2} \mathrm{NPs}$ had a higher MO degradation efficiency under UV 635 irradiation (73\%) than visible light irradiation (50\%). The doping of metals in the pure oxide 636 matrix served as electron-holes separation centers, which enhanced the degradation of MO 637 (Khairy \& Zakaria, 2014). Therefore, the introduction of doping metal ions can improve the 638 catalytic activity of $\mathrm{TiO}_{2} \mathrm{NPs}$ under visible light illumination.

\section{$640 \quad 4.3 \quad$ Heterogeneous catalysis}

641 In heterogeneous catalysis, the phase of the catalyst must be different from the phase of the

642 reactant. In general, heterogeneous catalysis involves a solid phase catalyst and a liquid phase

643 reactant. The catalysts are employed to enhance the reaction or adsorption rates. However, mass, 
644 heat transfer and thermodynamic parameters also affect the reaction rate (Sievers et al., 2016).

645 The most important parameter affecting the reaction rate of the catalyst is its surface area.

646 Heterogeneous catalysts can be used with NPs to improve the degradation of organic

647 contaminants due to the advanced oxidation capacity of the catalysts. Several oxidants such as

648 persulfate (PS), peroxymonosulfate (PMS) and hydrogen peroxide (HP) have been successfully

649 used for removing contaminants. nZVI coupled with common oxidants such as $\mathrm{NaClO}, \mathrm{KMnO}_{4}$

650 and $\mathrm{H}_{2} \mathrm{O}_{2}$ resulted in high removal efficiencies of $\mathrm{As}(\mathrm{V}), \mathrm{Cd}(\mathrm{II})$, and $\mathrm{Hg}(\mathrm{II})$ within only 10-30

651 min (Guo et al., 2016). nZVI with PS showed a high removal capacity of 1,4-dioxane and As(III)

652 from contaminated water, where the As(III) removal capacity of PS/nZVI was $115.27 \mathrm{mg} / \mathrm{g}$, and

653 the 1,4-dioxane degradation rate was $0.0347 \mathrm{~h} / \mathrm{mg} / \mathrm{min}$ (Kang et al., 2018). Similarly, PS/nZVI

654 removed nearly $97 \%$ of trichloroethene (TCE) in the presence of ethylenediaminetetraacetic acid 655 (Dong et al., 2017).

656 Bimetallic nZVI NPs were used for dual Fenton oxidation and reductive dechlorination of 2,4-

657 dichlorophenol. A nZVI-Fe/Pd heterogeneous catalyst composite showed an approximate $16 \%$

658 reductive dechlorination efficiency, and a 28\% Fenton oxidation efficiency for 2,4-

659 dichlorophenol (Li et al., 2015). A combined application of nZVI and bisulfite (S(IV)) revealed

660 that an increased $\mathrm{Fe}^{0}$ concentration in the $\mathrm{Fe}^{0} / \mathrm{S}(\mathrm{IV}) / \mathrm{O}_{2}$ system improved sulfamethoxazole

661 removal from aqueous media due to an accelerated activation of S(IV) and $\mathrm{Fe}^{0}$ corrosion (Du et 662 al., 2018).

663

\section{$664 \quad 4.4 \quad$ Electro-nanoremediation}

665 Pre-magnetization by the application of a weak magnetic field was suitable for promoting the 666 corrosion of $\mathrm{Fe}^{0}$, which might enhance the removal rates of contaminants by nZVI in soil and water 
667 systems (Pan et al., 2017). In view of this principle, electrolysis was applied to micro-sized Fe $668\left(\mathrm{mFe}^{0}\right)$ for $p$-nitrophenol (PNP) removal (Xiong et al., 2018b). The results suggested that the rate 669 constants of PNP removal by electrodialysed- $\mathrm{mFe}^{0}\left(\mathrm{Ele}^{\left.-\mathrm{mFe}^{0}\right)}\right.$ were $1.72-144.50$ fold higher than 670 those of pristine $\mathrm{mFe}^{0}$ under various conditions because the electrolysis aggravated the corrosion 671 of $\mathrm{mFe}^{0}$ by releasing Fe(II) ions (Xiong et al., 2018b). Similarly, a combined system of nZVI and 672 electro-kinetic remediation was used to study the transport and degradation of molinate in soils. 673 Molinate was degraded by nZVI in soils at slower rates than in an aqueous system due to the 674 heterogeneous nature of the soil (Gomes et al., 2014). The molinate degradation occurred via the 675 oxidative pathway, which involved oxygen and the formation of hydrogen peroxide and hydroxyl 676 radicals (Gomes et al., 2014). nZVI was employed along with electrokinetic treatment for the 677 degradation of chlorinated ethenes (CEs) in the presence of Dehalococcoides spp. and 678 Desulfitobacterium spp. (Czinnerová et al., 2020). The combined treatment resulted in a rapid $75 \%$ 679 decrease of cis-1,2-dichloroethene (cDCE) concentration in the contaminated area, and produced 680 methane, ethane, and ethene as the end products. The treated aquifer showed increased activity of 681 organohalide-respiring bacteria, and cDCE-oxidizing methanotrophs and ethenotrophs 682 proliferated near the anode under low oxygen conditions. The nZVI treatment resulted in mild 683 negative effect on indigenous bacteria, but the microbiome was restored within 15 days 684 (Czinnerová et al., 2020). Application of nZVI with a direct current (DC) electric field led to a 685 greater increase of CE remediation efficiency than nZVI alone in a study in the Czech Republic 686 (Černíková et al., 2020). This method was environmentally sound for improving CE reduction 687 efficiency by improving the longevity, migration and reactivity of the nZVI, and reduced the cost 688 of treatment by five times compared to bare nZVI (Černík et al., 2019; Černíková et al., 2020). 689 Only a limited number of studies have been conducted on the electro-nanoremediation of 
690

691

692

693

694

695

696

697

698

699

700

701

702

703

704

705

706

707

708 709 (Shanbhogue et al., 2017).

710

711

712 practical applications.

\subsection{Nano-bioremediation}

contaminants assisted by NMs, but the potential of this method must be explored in the future for

Biological technology offers cost-effectiveness and a low generation rate of toxic substances, but a relatively slower rate of remediation (Hou et al., 2020). Nano-bioremediation may be defined as the remediation of a contaminant using NPs and biological technology together for accelerating the removal/degradation rate of contaminants (Cecchin et al., 2017). The focus of the nano-bioremediation technique is to reduce the concentration of contaminants to a level where it becomes prone to biodegradation, and further reduce the contaminants to a safe limit through biodegradation. TCE was dechlorinated using a long-lasting emulsified colloidal substrate (LECS) that contained nZVI and microorganisms such as Dehalococcoides spp. and Desulfitobacterium spp. (Sheu et al., 2016). The supplement of LECS in TCE-polluted groundwater effectively stimulated the TCE dechlorination rate under anaerobic conditions (Sheu et al., 2016). Moreover, the population of Dehalococcoides sp. increased from $2 \times 10^{3}$ to $1.2 \times 10^{7}$ cells/L, and Desulfitobacterium sp. increased from $1 \times 10^{3}$ to $7.4 \times 10^{6}$ cells/L after 60 days. Similarly, TCE removal efficiency was promoted when nZVI was integrated with Dehalococcoides sp. BAV1 compared to systems with nZVI and Dehalococcoides sp. alone, and the optimum dose of nZVI for maintaining microbial activity was found to be $0.05 \mathrm{~g} / \mathrm{L}$

Integration of anaerobic bacteria such as organohalide respiring bacteria, sulfate reducing bacteria (SRB) and iron reducing bacteria (IRB) with nZVI also showed promising results in removing inorganic and organic pollutants (Dong et al., 2019). Here, nZVI provided reducing 
713 conditions, where the generated hydrogen acted as an electron donor for hydrogenotrophic

714 bacteria, resulting in the degradation of halogenated compounds. Xu et al. (2014) reported that

715 ZVI was able to reduce higher congeners of PBDEs to lower congeners, and subsequently

716 degradation was promoted by Dehalococcoides sp. CBDB1. Thus, complete degradation of

717 PBDEs was achieved by the integration of nZVI with Dehalococcoides sp. CBDB1.

718 The combination of nZVI and SRB has also improved heavy metal removal from contaminated 719 systems. Yi et al. (2009) reported that $98.1 \%$ of U(VI) was removed by a nZVI+SRB integrated 720 system within $4 \mathrm{~h}$ of reaction, while the removal rate of the individual system of ZVI and SRB 721 was 17.4 and $67.3 \%$, respectively. Under anaerobic conditions, SRB transformed sulfate into 722 sulfides (e.g., $\mathrm{H}_{2} \mathrm{~S}, \mathrm{~S}^{2-}$ and $\mathrm{HS}^{-}$) via the metabolism of organic matter. Then sulfide could bind 723 with heavy metals to form stable complexes with SRB metabolites (Kumar et al., 2015).

724 Similarly, Vogel et al. (2018) investigated the microbial degradation of PCE in the presence of 725 Sulfospirillum multivorans, Desulfitobacterium spp. and Dehalococcoides mccartyi together with 726 Carbo-iron NM. The study suggested that embedded nZVI decreased the redox potential of the 727 groundwater due to their reaction with oxygen, leading to nZVI-corrosion-induced formation of $728 \mathrm{H}_{2}$ within 190 days after the injection, the latter promoting sulphate-reducing conditions. 729 A similar approach to test the effectiveness of a hybrid system using nano scale zinc oxide (n$730 \mathrm{ZnO}$ ) and lindane-degrading yeast Candida VITJzN04 for lindane degradation was evaluated 731 (Salam \& Das, 2015). The half-life of the lindane was lower (9 h) with an embedded bio-nano 732 hybrid as compared to yeast Candida VITJzN04 (28 h); the enhanced lindane degradation by the 733 bio-nano hybrid was attributed to the increased porosity and permeability of the yeast cell

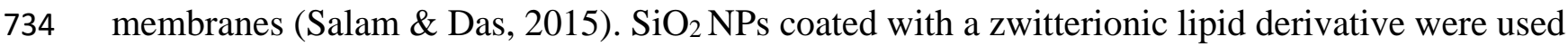
735 in the bioremediation of benzo[a]pyrene (Wang et al., 2015a). The authors used Pseudomonas 
736 aeruginosa, a gram-negative bacterium, and 1,2-dimyristoyl-sn-glycero-3-phosphocholine as a

737 source of lipids, which adsorbed and sequestered benzo[a]pyrene and maintained the colloidal

738 stability of NPs for their transport to the contaminant source (Wang et al., 2015a).

739 Another study using CMC-stabilized $\mathrm{Pd} / \mathrm{Fe}^{0}\left(\mathrm{CMC}-\mathrm{Pd} / \mathrm{nFe}^{0}\right) \mathrm{BNPs}$, and the microorganism

740 Sphingomonas sp. Strain NM05 targeted the degradation of hexachlorocyclohexane $(\gamma-\mathrm{HCH})$ in

741 soil and found that the $\gamma$-HCH degradation efficiency was $\sim 1.7-2.1$ times greater in the

742 integrated system than the control system (Singh et al., 2013). Dechlorination of the PCB

743 Aroclor 1248 was performed using Pd/nFe BNPs and Burkholderia xenovorans LB400 under

744 anoxic conditions. Toxic equivalent values of polychlorinated biphenyls (PCBs) decreased from

$74533.8 \times 10^{-5} \mu \mathrm{g} / \mathrm{g}$ to $9.5 \times 10^{-5} \mu \mathrm{g} / \mathrm{g}$ after the nano-bioremediation treatment (Le et al., 2015).

746 Apart from organic contaminants, attempts have been made to immobilize heavy metals in soil

747 through nano-bioremediation. Citrobacter freundii Y9, a Se reducing organism, secreted

748 biogenic nano-Se ${ }^{0}$, which converted $46-57$ and $39-49 \%$ of elemental mercury $\left(\mathrm{Hg}^{0}\right)$ in soils to its

749 insoluble mercuric selenide ( $\mathrm{Hg}-\mathrm{Se})$ form under oxygen-rich and oxygen-free conditions,

750 respectively. Furthermore, an addition of sodium dodecyl sulfonate enhanced soil $\mathrm{Hg}^{0}$

751 remediation due to the increased release of intracellular nano- $\mathrm{Se}^{0}$ from the bacterial cells (Wang

752 et al., 2017).

753

754 5. Practical applications

755 Studies on in-situ remediation using NMs are important, but available literature is limited. Most

756 field studies are confined to nZVI applications for contaminants removal from groundwater.

757 Therefore, we discuss in-situ remediation applications focusing on various practical modes of 
nanoremediation along with a few examples of real field scale studies as well as issues that need to be resolved for the large-scale field application of NMs for environmental remediation.

\subsection{Field-scale application of nZVI for groundwater remediation}

Nanoremediation using nZVI requires specific conditions to be met for achieving the most effective outcome. Appropriate site characteristics in terms of location, geological conditions, soil hydrogeological conditions (e.g., porosity, hydraulic gradient, groundwater velocity), and soil physico-chemical composition (e.g., pH, type and concentration of contaminants, dissolved oxygen level, concentration of other ions, redox potential) need to be determined before the injection of nZVI for contaminant remediation. The above would ascertain effective infiltration of nZVI in the contaminated zone, and help to ensure the efficient degradation or adsorption of specific contaminants at in-situ conditions (Karn et al., 2009). At the field-level, most of the applications of nZVI are concentrated on the degradation of chlorinated solvents. However, field studies were also found successful for treatment of halogenated organic compounds, PAHs, heavy metals (Ni, Cr(VI)), diesel fuel, PCBs, and pesticides (Bardos et al., 2018). In a case study, three types of non-pumping reactive wells (slanting, horizontal and vertical) were mixed with zero valent micro- (dose 0-4 g/L) and nano-sized iron $\left(\mathrm{Fe}^{0}\right)($ dose $0-2 \mathrm{~g} / \mathrm{L})$ for nitrate removal in groundwater (Hosseini et al., 2018). Removal was primarily dependent on the contact time of the reactant with nitrate and the zone captured by the tube wells. Slanted non-pumping reactive wells showed higher $\mathrm{NO}_{3}{ }^{-}$reduction rate (57\%) compared to the vertical (38\%) and horizontal (41\%) configurations (Hosseini et al., 2018). Earlier, nZVI was used to remove TCE from a groundwater aquifer $\left(80 \mathrm{~m}^{3}\right)$ with $1300 \mathrm{~L}$ total water capacity (Elliott \& Zhang, 2001). Here, approximately 1.7 $\mathrm{kg}$ of nZVI equivalent, yielding a $0.75-1.5 \mathrm{~g} / \mathrm{L}$ loading, was used to completely dechlorinate TCE 
781 over a period of 2 days. Similarly, Gavaskar et al. (2005) reported the field application of nZVI (at $7822 \mathrm{~g} / \mathrm{L}$ loading) for TCE removal in $68000 \mathrm{~L}$ water in $7300 \mathrm{~m}^{3}$ of aquifer volume. Furthermore, 783 complete reduction of TCE in groundwater was observed using emulsified nZVI (at $140 \mathrm{~g} / \mathrm{L}$ 784 loading) in an aquifer of $40 \mathrm{~m}^{3}$ with a $8500 \mathrm{~L}$ water capacity (Quinn et al., 2005). Chlorinated 785 hydrocarbons including TCE in the groundwater were also successfully removed using nZVI (at $78630 \mathrm{~g} / \mathrm{L}$ loading) in $75000 \mathrm{~L}$ of water in a $15000 \mathrm{~m}^{3}$ aquifer (Varadhi et al., 2005).

787

\subsection{Permeable reactive barriers and direct injection}

789 Permeable reactive barriers (PRB) consist of a permeable matrix that supports and anchors a reactive material to retain contaminants when a plume passes through the matrix. The main

791 challenge of PRB systems is the costliness of the reactive barrier materials in removing target 792 contaminants at desired levels (Tasharrofi et al., 2020). A nZVI-zeolite composite was evaluated 793 to overcome the cost limitation of reactive materials in a PRB system to remediate aqueous 794 Cd(II) (Tasharrofi et al., 2020). The zeolite was able to disperse nZVI well, and prevented its 795 agglomeration. The nZVI-zeolite composite adsorbed $20.6 \mathrm{~g} / \mathrm{kg} \mathrm{Cd}(\mathrm{II})$ within $90 \mathrm{~min}$ (initial $796 \mathrm{Cd}(\mathrm{II})$ concentration $50 \mathrm{mg} / \mathrm{L})$, and discharged very low levels of $\mathrm{Cd}(\mathrm{II})$ back into the 797 environment, making the material suitable for application in PRBs (Tasharrofi et al., 2020).

798 Under a pilot scale application in the Czech Republic, nZVI was injected to successfully remove 799 chlorinated hydrocarbons on a short-term basis before the installation of a complete PRB 800 remediation system. The nZVI injection prevented the migration of contaminants to adjacent 801 areas outside the PRB (Bone et al., 2020). Direct injection can be used for both contaminant 802 source and pathway treatments. A known quantity of nZVI is applied to a known depth of an 803 aquifer either by gravity or by introducing pressure. The injection processes may include: (a) 
804 direct push or a stationary injection point to emplace a nZVI slurry in the treatment zone, (b)

805 hydraulic fracturing using air or water to create preferential flow, (c) liquid atomization (i.e., 806 pulses of pressure during injection), and (d) injection through a carrier (e.g., surfactant) for 807 delivery of nZVI in the vadose zone (Ding et al., 2013). Apart from trialling PRB and direct 808 injection technologies under field conditions, future research should concentrate on the 809 development of inexpensive and efficient modes of in-situ nanoremediation.

\section{$811 \quad 5.3 \quad$ Issues with field application of nanomaterials for remediation}

812 Field scale applications of various NMs in addition to nZVI are urgently needed for

813 environmental remediation including soil contaminants treatment. However, the following issues

814 should be considered to enhance the practical utility of nanoremediation.

815 (1) One of the key concerns of NMs application is the lack of dose optimization. High 816 application rates of NMs in water may be useful for removing a target contaminant, but it can be 817 a serious concern when applied to soil. The large quantity of NMs required for remediating 818 contaminated soils at the field scale is unmanageable using conventional production facilities. In 819 addition, high concentrations of NPs (e.g., nZVI) may cause toxicity to microorganisms (Dong et 820 al., 2019).

821 (2) Standard protocols to apply NMs for environmental remediation are still lacking.

822 Therefore, appropriate application procedures for different NMs need to be documented and 823 updated for field scale applications.

824 (3) Regeneration of applied NMs in soil needs further investigation. It is difficult to separate 825 NMs from soil once they are added or injected because soil itself is a highly heterogeneous 826 medium. Adsorbed contaminants may desorb from the nanoadsorbents after some period. 
827 (4) Various NMs such as CNTs and GO, and NPs such as BNPs, polymer NPs, and Cu- and

828 Fe-based NPs are quite expensive but have enormous potential for both organic and inorganic

829 contaminant remediation at the field scale. Green synthesis techniques (as applied for nZVI)

830 should also be considered for these NMs to minimize environmental toxicity.

831 (5) The impact and fate of applied NMs on aquatic and soil organisms should be studied

832 thoroughly before application to test their ecological and environmental safety (Besha et al., 833 2020).

834 (6) Optimum operational factors (e.g., competing ions, pH, time, organic matter, 835 temperature) of various NMs for remediating various contaminants requires standardization at 836 the field level due to the heterogeneous nature of field sites.

\section{Environmental risk of nanomaterials}

839 The potentially vast applications of NMs for remediating contaminated soil and water have earned widespread research attention; studies have specifically vied to understand the

841 mechanisms of NM interactions with environmental components, microbial communities and 842 target contaminants (Biswas \& Sarkar, 2019; Rai \& Biswas, 2018). The deposition of NMs in the 843 environment through soil and wastewater treatment processes has been reported to cause toxicity 844 to microorganisms such as bacteria including plant growth promoting rhizobacteria (Lewis et al., 845 2019). nZVI is the most widely used NPs for the remediation of various contaminants in the 846 environment. The fate of NPs, particularly in soils, depends on several key parameters, such as 847 soil texture, $\mathrm{pH}$ and organic matter contents. nZVI might have toxic effects on microbial communities (Lefevre et al., 2016). For example, nZVI disrupted microbial cells by producing reactive oxygen species that caused cytotoxicity and changed the population and functional 
850 composition of the microbial community (Lefevre et al., 2016). Similarly, nZVI particles at high

851 concentrations showed a strain dependent antibacterial effect on Escherichia coli leading to cell

852 inactivation via oxidative stress (Chaithawiwat et al., 2016a). Gram negative bacteria were more

853 susceptible to nZVI toxicity than Gram positive bacteria (Chaithawiwat et al., 2016a).

854 Chaithawiwat et al. (2016b) reported that the rpoS gene was mainly responsible for resisting

855 nZVI toxicity at cellular level. Unlike E. coli, Pseudomonas putida F1 exhibited high tolerance

856 to $\mathrm{nZVI}$ at a $0.1 \mathrm{~g} / \mathrm{L}$ dose by virtue of the rigid cell membrane of the bacterium (Kotchaplai et al.,

857 2017).

858 Since $\mathrm{nZVI}$ is an efficient As(V) removal agent in aqueous systems, the effects of its excessive 859 application on plants was studied using Arabidopsis thaliana grown hydroponically (Zhang et 860 al., 2018b). Biosensors for inorganic phosphate (Pi) and $\mathrm{Mg}$-ATP ${ }^{2-}$ were used to monitor in vivo $861 \mathrm{Pi}$ and $\mathrm{Mg}_{\mathrm{ATP}}{ }^{2-}$ levels in the cells. An excess nZVI exposure resulted in Pi starvation in plants, 862 leading to adverse effects on plant growth (Zhang et al., 2018b). Additionally, earthworm species 863 such as Eisenia fetida and Lumbricus rubellus were also affected by the application of nZVI in 864 soil at a high dose $(500 \mathrm{mg} / \mathrm{kg})$. However, aging or oxidation of nZVI may reduce its toxicity 865 level (El-Temsah \& Joner, 2012). For example, Fajardo et al. (2015) reported that aged nZVI had 866 no adverse effects on soil physico-chemical properties and Caenorhabditis elegans in a Zn867 contaminated soil, although the Fe content in the soil was increased. However, in contrast to the $868 \mathrm{Zn}$-contaminated soil, the growth of C. elegans was decreased in a nZVI-treated Pb-polluted soil 869 (Fajardo et al., 2015).

870 Based on ecotoxicity tests performed by Hjorth et al. (2017), most nZVI products would receive 871 no environmental hazard classification according to European regulations, except for the ball872 milled nZVI particles; none of the other nZVI particles showed toxicity below a $100 \mathrm{mg} / \mathrm{L}$ 
873 concentration. An injection of nZVI to $\mathrm{Cr}(\mathrm{VI})$-contaminated water rapidly decreased total $\mathrm{Cr}(\mathrm{VI})$

874 in the groundwater, whereas an ecotoxicological test on Vibrio fischeri with nZVI did not

875 indicate any negative changes on the toxicity of the groundwater (based on the cultivable

876 psychrophilic bacteria population and phospholipid fatty acid analysis) (Němeček et al., 2014).

877 It is not clear whether NPs of metal oxides or metal salts are toxic to aquatic organisms.

878 Microarray results suggested that exposure of Daphnia magna to $\mathrm{CuO}$ and $\mathrm{ZnO} \mathrm{NPs}$ and their 879 metallic salts had no significant differences between the species' transcribed gene fragments 880 (Adam et al., 2015). It was elucidated that the toxicity of $\mathrm{ZnO}$ and $\mathrm{CuO}$ NPs to $D$. magna was 881 solely caused by toxic metal ions (Adam et al., 2015). Ti-based NPs also showed deleterious 882 effects on microorganisms in soil ( $\mathrm{Li}$ et al., 2016); hence, they should be replaced with less toxic 883 metal oxide NPs such as $\mathrm{Zn}, \mathrm{Fe}$ and $\mathrm{Cu}$, where possible.

884 Toxicity of the NPs in water, particularly Fe NPs (e.g., nZVI), also depends on the mixing and 885 dispersing agents present. There may be residual NPs in water even after pollutant removal is 886 complete (Peeters et al., 2016). The dispersion of Fe NPs with tetramethylammonium hydroxide 887 (TMAH) resulted in a slower settling of the iron aggregates. In Milli-Q and forest spring waters 888 treated with Fe NPs and dispersed by TMAH, the nano iron remained in solution for a day after 889 the treatment, which represented a residual effect and may pose a threat to aquatic ecosystems 890 (Peeters et al., 2016). Likewise, during the use of nano- $\mathrm{TiO}_{2}$ in aqueous systems, a combination 891 of humic acid and $\mathrm{HCO}_{3}{ }^{-}$increased the release of Ti in water. Olabarrieta et al. (2018) reported 892 that the nano- $\mathrm{TiO}_{2}$ rejection rate was generally above $95 \%$ in a low-pressure membrane filtration 893 pilot plant, and $2.3 \mathrm{~g}$ of the NPs could be released when treating $31 \mathrm{~m}^{3}$ of tap water with $2 \mathrm{mg} / \mathrm{L}$ 894 nano- $\mathrm{TiO}_{2}$. 
895 CNTs can be toxic toward bacteria at the cellular level. SWCNTs with varying functional groups

896 altered the gene and protein expressions of E. coli at even a low SWCNT concentration (10

$897 \mu \mathrm{g} / \mathrm{mL}$ ) causing cell perturbation (Anh Le et al., 2019). In contrast, CNT toxicity to bacteria

898 could be eliminated by entrapping CNTs using polymeric gels such as alginate and poly vinyl

899 alcohol (Le et al., 2016).

900 One of the key concerns in the treatment and remediation of chemical contaminants with NMs is

901 the introduction of little-known man-made materials to the environment/nature. This stigma

902 needs to be overcome to gain public acceptance of nanoremediation technologies. Risk

903 assessments of engineered NMs have been conducted for at least two decades, and the perception

904 of risk has begun to change to some extent. For example, Ag-based NPs, which are mainly used

905 for antimicrobial activity and were thought to be very harmful to the environment, were found to

906 pose a small overall risk to terrestrial environments because (1) only a small fraction of Ag NPs

907 ultimately enter into the soil, (2) the nano-properties and activities of Ag NPs are diminishable

908 quickly when present in the soil, and (3) only minor bioaccumulation of Ag occurs in edible

909 plant parts (Wang et al., 2018). Moreover, researchers have advocated the application of NM-

910 based fertilizers and pesticides (e.g., Fe-, $\mathrm{Cu}-, \mathrm{Mg}-, \mathrm{Mn}-, \mathrm{Si}-$ based NMs) directly to soil and/or

911 on the plant bodies because these NMs pose negligible environmental risks but support crop

912 production (Adisa et al., 2019; Kopittke et al., 2019). Nevertheless, NMs of various types may be

913 associated with different risks, which should be researched thoroughly before their application

914 for environmental remediation.

915

$916 \quad$ 7. Risk management applications of nanoremediation 
917 Risk management includes three strategies: (i) contaminant removal at the source, (ii) plume 918 control or pathway treatment, and (iii) limiting the use of resources. Risk management can be 919 achieved by eliminating contaminants at their source point and destroying the linkage between 920 contaminant sources, pathways (migration of contaminants), and receptors (Nathanail \& Bardos, 921 2004). However, complete mass removal of contaminants at the source is quite difficult due to 922 residues and the presence of non-aqueous phase liquids (NAPL) (e.g., chlorinated solvents), 923 contributing to low concentrations of contaminants that are still in excess of regulatory 924 groundwater threshold values (Gavaskar et al., 2005). nZVI is capable of managing source and 925 pathway treatments under in-situ conditions in the host geologic material as well as in 926 groundwater. The application of nZVI in geologic media through direct injection can cause the in927 situ degradation of organic contaminants, and adsorption and transformation of inorganic 928 contaminants due to $\mathrm{pH}$ and redox potential changes (Pasinszki \& Krebsz, 2020; Stefaniuk et al., 929 2016). In groundwater, nZVI application by direct injection into the in-situ source zone, or via 930 groundwater funneling to an in-situ treatment zone (e.g., PRB), and using integrated approaches 931 (e.g., nano-bioremediation, electro-nanoremediation) are effective risk management applications 932 of nanoremediation (Bardos et al., 2015). Bioengineering approaches such as using biomarkers (a 933 tool of biological monitoring) to track nZVI during contaminant treatment may effectively 934 minimize the risk of release of contaminant-loaded NMs into the environment (Patil et al., 2016). 935 Permeable iron barriers in shallow aquifers capable of collecting nZVI after use could also be 936 useful for minimizing the further release of NMs into the system (Patil et al., 2016). However, 937 risk management studies involving other NMs under field conditions are currently scarce, and 938 warrant future research. 


\section{Societal and economic implications}

941 Sustainable remediation involves the elimination or control of a contamination risk in a safe and

942 timely manner, while optimizing the environmental, social, and economic values of the work

943 (Nathanail et al., 2017). Sustainable remediation may comprise of one or multiple remediation

944 technologies including in-situ and ex-situ treatments, and a combination of physical, chemical,

945 thermal and biological processes (Nathanail et al., 2017). The International Standard for

946 Organization (ISO) has taken the policy, legislations, and practices for risk management around

947 the world through committee draft ISO/CD 18504, and published international standard ISO/DIS

948 18504. To make the concept widely popular and comprehensive to end users (practitioners,

949 regulators, and stakeholders in land quality), clear definitions of the approaches, standard

950 methodologies, and demonstrations of specific remediation strategies are the need of the hour. The

951 approaches should meet the three pillars of sustainable remediation: (a) inexpensive, (b) eco-

952 friendly, and (c) acceptable to society.

953

$954 \quad$ 8.1 Societal implications

955 While in-situ nanoremediation has become environmentally and socially sustainable (Corsi et al., 956 2018), exposures of human beings to NMs through drinking of water, inhalation of polluted air, 957 and contact with skin, potentially leading to health problems involving the lungs, liver,

958 respiratory system, and brain. To overcome these barriers, monitoring and interventions must be

959 performed. To promote this technology without causing harm to humans, the following steps

960 must be considered (Corsi et al., 2018):

961 (1) Nanoremediation techniques (success stories) requires documentation in a simple and 962 comprehensive manner. 
963 (2) Development of standard protocols is needed to evaluate the ecosafety and economic 964 sustainability of NMs.

965 (3) Manufacturers need to inform the consumers via proper labeling of products of the level of 966 risks, potential ecotoxicity, health impact and risk management of nanoproducts.

967 (4) Science-Policy-Interfacing in needed through conversations among scientists,

968 Government/non-Governmental officials and extension workers about the benefits and potential 969 hazards of NMs, and the hazard mitigation strategies.

970 (5) High quality and thoroughly validated information (including levels of risks) are needed for a 971 policy framework to encourage in-situ uses of NMs for treating contaminated soil and water.

\section{$973 \quad 8.2 \quad$ Economic implications}

974 The costs of remediation technologies encompass capital costs, reagent costs, maintenance, 975 overhead costs and operational costs. The use of nZVIs for remediating organic pollutants such 976 as TCE, chloramphenicol, lindane, and heavy metals such as $\mathrm{Pb}, \mathrm{Zn}, \mathrm{As}, \mathrm{Cr}, \mathrm{Cd}$, and $\mathrm{Pb}$, is less 977 expensive than existing advanced technologies such as membrane and ozonation (Adeleye et al., 978 2016). Current technologies such as adsorption and precipitation for heavy metal remediation 979 generate substantial solid waste production that can be mitigated by the effective application of 980 nanoremediation technologies (metal oxides and nZVI). For $\mathrm{As}$ and $\mathrm{NO}_{3}{ }^{-}$remediation, using 981 nZVI appears to be less expensive than carbon-based nanotechnologies (Adeleye et al., 2016).

982 Although a laboratory scale experiment requires substantially lower amounts of nZVIs, costs for 983 a field scale application are still high. nZVI production costs are approximately $\$ 0.05-0.10 / \mathrm{g}$, 984 whereas micro and bulk $\mathrm{Fe}^{0}$ cost less than $\$ 0.001 / \mathrm{g}$ to produce (Adeleye et al., 2016). $\mathrm{TiO}_{2} \mathrm{NPs}$ 985 are currently available at prices ranging from roughly $\$ 0.03 / \mathrm{g}$ to $\$ 1.21 / \mathrm{g}$ (Lu et al., 2011). 
Photocatalysts can potentially be regenerated, as they are hardly degraded during oxidized radical production (Kim et al., 2012), and have potential to further decrease the overall costs associated with using photocatalytic metal oxide NPs for water treatment. Similarly, for carbonbased NMs, the cost of nanotechnology varies widely depending upon the material type, functionalization, purity level (wt. \%), and grade. Currently, prices range between $\$ 2.50$ - 1000/g

991 for graphene and derivatives, \$0.10 - 25/g for MWCNTs and \$25 - 300/g for SWCNTs. Aqueous $992 \mathrm{~Pb}(\mathrm{II})$ removal using $\mathrm{SWCNTs}$ via adsorption may cost an average of $\$ 2.2 / \mathrm{g}-\mathrm{Pb}$ (Adeleye et al., 993 2016). However, carbon-based NMs are extremely expensive from a remediation point of view. 994 The best way to reduce the cost is to further develop regeneration and recycling strategies for nanomaterials. Improved marketability of nanoremediation technology can potentially be 996 achieved via: (1) encouraging NM synthesis from inexpensive renewable sources such as leaf 997 extracts, agro-wastes, microorganisms, and natural clay minerals, and (2) identifying factors that 998 govern the acceptability of the technology among various stakeholders, and taking regional and need-based adoption strategies.

\section{Conclusions and future outlooks}

1002 The NMs discussed in this article exhibit high potential for the remediation of contaminated soil 1003 and water. Inorganic and organic modification of NPs along with supporting agents such as clay 1004 minerals, biochar, biodegradable polymers, and minimal amounts of zeolite improves the 1005 contaminant removal capacity of the NMs. The high degradation capacities and 1006 photodegradation efficiencies of NMs, and their possible uses as mediums to target multiple 1007 contaminants hold great promise. The practical field application of NMs is, however, still limited 1008 to nZVI for soil and groundwater remediation. NMs may pose positive or negative impacts on 
1009 living organisms, the environment, society and economy, which should be evaluated in a case-

1010 specific context. Appropriate documentation of NM risks, field scale validation of remediation

1011 results, science-policy interface consultations, and suitable market development initiatives are

1012 ways to increase the popularity and acceptability of nanoremediation technologies.

1013 We put forward the following research challenges for a wider acceptability of nanoremediation

1014 technologies:

1015 (1) Future research on both the fundamental and practical aspects of nano-bioremediation is

1016 recommended. The operational conditions of nano-bioremediation such as $\mathrm{pH}$, dosage,

1017 temperature, and solution composition should be optimized to work in real, field contaminated

1018 systems.

1019 (2) Molecular mechanisms of biological degradation and removal in nano-bioremediation 1020 techniques need further investigation.

1021 (3) Since soil is a complex and heterogeneous system, efficient soil remediation techniques 1022 must be developed. The influence of the application of NMs on soil geochemistry, microbiology, 1023 and ultimately toxicity in soil systems should be further studied.

1024 (4) Most extant research on nanoremediation is confined to laboratory studies and modeling.

1025 Transferring these studies to in situ conditions is a challenge. Systematic experimentation of the 1026 impact of NMs on soil environments is needed in order to develop standard protocols and doses 1027 for the application of NMs at the field level.

1028 (5) Supporting NMs on inert materials such as activated carbon (e.g., Carbo-iron), clay 1029 minerals, polymers, zeolite, and biochar is believed to improve contaminant remediation 1030 performance while simultaneously reducing unwanted risks of NMs to terrestrial and aquatic 1031 organisms. This requires future research attention for field validation and uptake by industry. 
1032 (6) Ecotoxicological and risk assessment studies of NMs are still limited to specific bacteria 1033 and their strains. Studies on the effect of NMs on diverse living organisms, including humans, 1034 and evaluation of toxicity transmission along the food chain are the need of the hour.

1035

1036 Acknowledgements

1037 This work was carried out with support from Lancaster Environment Centre Project, and 1038 Cooperative Research Program for Agriculture Science and Technology Development 1039 (Project No. PJ01475801), Rural Development Administration, Republic of Korea, National 1040 Research Foundation of Korea (NRF) (NRF-2015R1A2A2A11001432), and NRF Germany1041 Korea Partnership Program (GEnKO Program) (2018-2020). This work was also supported in 1042 part by the Queensland node of the Australian National Fabrication Facility (ANFF), a company 1043 established under the National Collaborative Research Infrastructure Strategy to provide nano 1044 and microfabrication facilities for Australia's researchers.

1045

1046 Conflicts of interest

1047 There is no conflict of interest to declare.

1048

1049 Contributions

1050 RM, BS and YSO conceptualized the work. RM and BS prepared the first draft, and revised the 1051 manuscript. All authors provided input on sections in later drafts and edited the manuscript. 
Adam, N., Vergauwen, L., Blust, R., Knapen, D. 2015. Gene transcription patterns and energy reserves in Daphnia magna show no nanoparticle specific toxicity when exposed to $\mathrm{ZnO}$ and $\mathrm{CuO}$ nanoparticles. Environmental Research, 138, 82-92.

Adeleye, A.S., Conway, J.R., Garner, K., Huang, Y., Su, Y., Keller, A.A. 2016. Engineered nanomaterials for water treatment and remediation: Costs, benefits, and applicability. Chemical Engineering Journal, 286, 640-662.

Adisa, I.O., Pullagurala, V.L.R., Peralta-Videa, J.R., Dimkpa, C.O., Elmer, W.H., Gardea-Torresdey, J.L., White, J.C. 2019. Recent advances in nano-enabled fertilizers and pesticides: a critical review of mechanisms of action. Environmental Science: Nano, 6(7), 2002-2030.

Ahmad, S.Z.N., Wan Salleh, W.N., Ismail, A.F., Yusof, N., Mohd Yusop, M.Z., Aziz, F. 2020. Adsorptive removal of heavy metal ions using graphene-based nanomaterials: toxicity, roles of functional groups and mechanisms. Chemosphere, 248, 126008.

Akbari Shorgoli, A., Shokri, M. 2017. Photocatalytic degradation of imidacloprid pesticide in aqueous solution by $\mathrm{TiO}_{2}$ nanoparticles immobilized on the glass plate. Chemical Engineering Communications, 204(9), 1061-1069.

Alam, M.S., Bishop, B., Chen, N., Safari, S., Warter, V., Byrne, J.M., Warchola, T., Kappler, A., Konhauser, K.O., Alessi, D.S. 2020. Reusable magnetite nanoparticles - biochar composites for the efficient removal of chromate from water. Scientific Reports, 10, 19007.

Al-Mamun, M.R., Kader, S., Islam, M.S., Khan, M.Z.H. 2019. Photocatalytic activity improvement and application of UV-TiO2 photocatalysis in textile wastewater treatment: A review. Journal of Environmental Chemical Engineering, 7(5), 103248.

Alarcón-Payán, D.A., Koyani, R.D., Vazquez-Duhalt, R. 2017. Chitosan-based biocatalytic nanoparticles for pollutant removal from wastewater. Enzyme and Microbial Technology, 100, 71-78.

Alver, E., Bulut, M., Metin, A.Ü., Çiftçi, H. 2017. One step effective removal of Congo Red in chitosan nanoparticles by encapsulation. Spectrochimica Acta Part A: Molecular and Biomolecular Spectroscopy, 171, 132-138.

Anh Le, T.T., Thuptimdang, P., McEvoy, J., Khan, E. 2019. Phage shock protein and gene responses of Escherichia coli exposed to carbon nanotubes. Chemosphere, 224, 461-469.

Anjum, M., Miandad, R., Waqas, M., Gehany, F., Barakat, M.A. 2019. Remediation of wastewater using various nano-materials. Arabian Journal of Chemistry, 12(8), 4897-4919.

Arenas-Lago, D., Rodríguez-Seijo, A., Lago-Vila, M., Couce, L.A., Vega, F.A. 2016. Using $\mathrm{Ca}_{3}\left(\mathrm{PO}_{4}\right)_{2}$ nanoparticles to reduce metal mobility in shooting range soils. Science of The Total Environment, 571, 1136-1146.

Awad, A.M., Jalab, R., Benamor, A., Nasser, M.S., Ba-Abbad, M.M., El-Naas, M., Mohammad, A.W. 2020. Adsorption of organic pollutants by nanomaterial-based adsorbents: An overview. Journal of Molecular Liquids, 301, 112335.

Baragaño, D., Forján, R., Welte, L., Gallego, J.L.R. 2020. Nanoremediation of As and metals polluted soils by means of graphene oxide nanoparticles. Scientific Reports, 10(1), 1896.

Bardos, P., Bone, B., Daly, P., Jones, S., Elliott, D., Lowry, G., Merly, C., Bartke, S., Braun, J., Harries, N., Hartog, N., Hofmann, T., Wagner, S., Nathanail, P. 2015. A Risk/Benefit Appraisal for the Application of Nano-Scale Zero Valent Iron (nZVI) for the Remediation of Contaminated Sites. NanoRem; http://www.nanorem.eu/Displaynews.aspx?ID=525.

Bardos, P., Merly, C., Kvapil, P., Koschitzky, H.-P. 2018. Status of nanoremediation and its potential for future deployment: Risk-benefit and benchmarking appraisals. Remediation Journal, 28(3), 43-56.

Bassyounia, M., Abdel-Aziz, M.H., Zorombab, M.S., Abdel-Hamide, S.M.S., Drioli, E. 2019. A review of polymeric nanocomposite membranes for water purification. Journal of Industrial and Engineering Chemistry, 73, 19-46.

Besha, A.T., Liu, Y., Bekele, D.N., Dong, Z., Naidu, R., Gebremariam, G.N. 2020. Sustainability and environmental ethics for the application of engineered nanoparticles. Environmental Science \& Policy, 103, 85-98. 
Bezbaruah, A.N., Krajangpan, S., Chisholm, B.J., Khan, E., Elorza Bermudez, J.J. 2009. Entrapment of iron nanoparticles in calcium alginate beads for groundwater remediation applications. Journal of Hazardous Materials, 166(2), 1339-1343.

Bezbaruah, A.N., Shanbhogue, S.S., Simsek, S., Khan, E. 2011. Encapsulation of iron nanoparticles in alginate biopolymer for trichloroethylene remediation. Journal of Nanoparticle Research, 13(12), 6673-6681.

Biswas, J.K., Sarkar, D. 2019. Nanopollution in the aquatic environment and ecotoxicity: no nano issue! Current Pollution Reports, 5(1), 4-7.

Bleyl, S., Kopinke, F.-D., Mackenzie, K. 2012. Carbo-Iron ${ }^{\circledR}$ —Synthesis and stabilization of Fe(0)doped colloidal activated carbon for in situ groundwater treatment. Chemical Engineering Journal, 191, 588-595.

Bone, B., Bardos, P., Edgar, S., Kvapil, P. 2020. Chapter 14 - The sustainability of nanoremediationtwo initial case studies from Europe. in: Sustainable Remediation of Contaminated Soil and Groundwater, (Ed.) D. Hou, Butterworth-Heinemann, pp. 367-404.

Cai, C., Zhao, M., Yu, Z., Rong, H., Zhang, C. 2019. Utilization of nanomaterials for in-situ remediation of heavy metal(loid) contaminated sediments: A review. Science of The Total Environment, 662, 205-217.

Çalışkan Salihi, E., Wang, J., Kabacaoğlu, G., Kırkulak, S., Šiller, L. 2020. Graphene oxide as a new generation adsorbent for the removal of antibiotics from waters. Separation Science and Technology, 1-9.

Cecchin, I., Reddy, K.R., Thomé, A., Tessaro, E.F., Schnaid, F. 2017. Nanobioremediation: Integration of nanoparticles and bioremediation for sustainable remediation of chlorinated organic contaminants in soils. International Biodeterioration \& Biodegradation, 119, 419-428.

Černík, M., Nosek, J., Filip, J., Hrabal, J., Elliott, D.W., Zbořil, R. 2019. Electric-field enhanced reactivity and migration of iron nanoparticles with implications for groundwater treatment technologies: Proof of concept. Water Research, 154, 361-369.

Černíková, M., Nosek, J., Černík, M. 2020. Combination of nZVI and DC for the in-situ remediation of chlorinated ethenes: An environmental and economic case study. Chemosphere, 245, 125576.

Chaithawiwat, K., Vangnai, A., McEvoy, J.M., Pruess, B., Krajangpan, S., Khan, E. 2016a. Impact of nanoscale zero valent iron on bacteria is growth phase dependent. Chemosphere, 144, 352-359.

Chaithawiwat, K., Vangnai, A., McEvoy, J.M., Pruess, B., Krajangpan, S., Khan, E. 2016b. Role of oxidative stress in inactivation of Escherichia coli BW25113 by nanoscale zero-valent iron. Science of The Total Environment, 565, 857-862.

Chang, P.-H., Chou, T.-H., Sahu, R.S., Shih, Y.-h. 2019. Chemical reduction-aided zerovalent copper nanoparticles for 2,4-dichlorophenol removal. Applied Nanoscience, 9(3), 387-395.

Chekli, L., Bayatsarmadi, B., Sekine, R., Sarkar, B., Shen, A.M., Scheckel, K.G., Skinner, W., Naidu, R., Shon, H.K., Lombi, E., Donner, E. 2016. Analytical characterisation of nanoscale zerovalent iron: A methodological review. Analytica Chimica Acta, 903, 13-35.

Chen, Y., Wang, D., Zhu, X., Zheng, X., Feng, L. 2012. Long-term effects of copper nanoparticles on wastewater biological nutrient removal and $\mathrm{N}_{2} \mathrm{O}$ generation in the activated sludge process. Environmental Science \& Technology, 46(22), 12452-12458.

Chong, M.N., Jin, B., Chow, C.W.K., Saint, C. 2010. Recent developments in photocatalytic water treatment technology: A review. Water Research, 44(10), 2997-3027.

Corsi, I., Winther-Nielsen, M., Sethi, R., Punta, C., Della Torre, C., Libralato, G., Lofrano, G., Sabatini, L., Aiello, M., Fiordi, L., Cinuzzi, F., Caneschi, A., Pellegrini, D., Buttino, I. 2018. Ecofriendly nanotechnologies and nanomaterials for environmental applications: Key issue and consensus recommendations for sustainable and ecosafe nanoremediation. Ecotoxicology and Environmental Safety, 154, 237-244.

Czinnerová, M., Vološčuková, O., Marková, K., Ševců, A., Černík, M., Nosek, J. 2020. Combining nanoscale zero-valent iron with electrokinetic treatment for remediation of chlorinated ethenes and promoting biodegradation: A long-term field study. Water Research, 175, 115692.

de Souza, R.M., Seibert, D., Quesada, H.B., de Jesus Bassetti, F., Fagundes-Klen, M.R., Bergamasco, R. 2020. Occurrence, impacts and general aspects of pesticides in surface water: A review. Process Safety and Environmental Protection, 135, 22-37. 
Ding, L., Li, J., Liu, W., Zuo, Q., Liang, S.-X. 2017. Influence of nano-hydroxyapatite on the metal bioavailability, plant metal accumulation and root exudates of Ryegrass for phytoremediation in lead-polluted soil. International Journal of Environmental Research and Public Health, 14(5), 532.

Ding, Y., Liu, B., Shen, X., Zhong, L., Li, X. 2013. Foam-assisted delivery of nanoscale zero valent iron in porous media. Journal of Environmental Engineering, 139(9), 1206-1212.

Dong, H., He, Q., Zeng, G., Tang, L., Zhang, L., Xie, Y., Zeng, Y., Zhao, F. 2017. Degradation of trichloroethene by nanoscale zero-valent iron (nZVI) and nZVI activated persulfate in the absence and presence of EDTA. Chemical Engineering Journal, 316, 410-418.

Dong, H., Li, L., Lu, Y., Cheng, Y., Wang, Y., Ning, Q., Wang, B., Zhang, L., Zeng, G. 2019. Integration of nanoscale zero-valent iron and functional anaerobic bacteria for groundwater remediation: A review. Environment International, 124, 265-277.

Du, J., Guo, W., Wang, H., Yin, R., Zheng, H., Feng, X., Che, D., Ren, N. 2018. Hydroxyl radical dominated degradation of aquatic sulfamethoxazole by $\mathrm{Fe}^{0} /$ bisulfite $/ \mathrm{O}_{2}$ : Kinetics, mechanisms, and pathways. Water Research, 138, 323-332.

Ebrahim, S.E., Sulaymon, A.H., Saad Alhares, H. 2016. Competitive removal of $\mathrm{Cu}^{2+}, \mathrm{Cd}^{2+}, \mathrm{Zn}^{2+}$, and $\mathrm{Ni}^{2+}$ ions onto iron oxide nanoparticles from wastewater. Desalination and Water Treatment, 57(44), 20915-20929.

El-Temsah, Y.S., Joner, E.J. 2012. Ecotoxicological effects on earthworms of fresh and aged nanosized zero-valent iron (nZVI) in soil. Chemosphere, 89(1), 76-82.

El-Temsah, Y.S., Sevcu, A., Bobcikova, K., Cernik, M., Joner, E.J. 2016. DDT degradation efficiency and ecotoxicological effects of two types of nano-sized zero-valent iron (nZVI) in water and soil. Chemosphere, 144, 2221-2228.

Elliott, D.W., Zhang, W.-x. 2001. Field Assessment of Nanoscale Bimetallic Particles for Groundwater Treatment. Environmental Science \& Technology, 35(24), 4922-4926.

ElShafei, G.M.S., Yehia, F.Z., Dimitry, O.I.H., Badawi, A.M., Eshaq, G. 2014. Ultrasonic assistedFenton-like degradation of nitrobenzene at neutral $\mathrm{pH}$ using nanosized oxides of $\mathrm{Fe}$ and $\mathrm{Cu}$. Ultrasonics Sonochemistry, 21(4), 1358-1365.

Ersan, G., Apul, O.G., Perreault, F., Karanfil, T. 2017. Adsorption of organic contaminants by graphene nanosheets: A review. Water Research, 126, 385-398.

Esmaeili, A., Khoshnevisan, N. 2016. Optimization of process parameters for removal of heavy metals by biomass of $\mathrm{Cu}$ and Co-doped alginate-coated chitosan nanoparticles. Bioresource Technology, 218, 650-658.

Fajardo, C., Gil-Díaz, M., Costa, G., Alonso, J., Guerrero, A.M., Nande, M., Lobo, M.C., Martín, M. 2015. Residual impact of aged nZVI on heavy metal-polluted soils. Science of The Total Environment, 535, 79-84.

Fajardo, C., Sánchez-Fortún, S., Costa, G., Nande, M., Botías, P., García-Cantalejo, J., Mengs, G., Martín, M. 2020. Evaluation of nanoremediation strategy in a $\mathrm{Pb}, \mathrm{Zn}$ and $\mathrm{Cd}$ contaminated soil. Science of The Total Environment, 706, 136041.

Floris, B., Galloni, P., Sabuzi, F., Conte, V. 2017. Metal systems as tools for soil remediation. Inorganica Chimica Acta, 455, 429-445.

Garcia, J., Gomes, H.T., Serp, P., Kalck, P., Figueiredo, J.L., Faria, J.L. 2006. Carbon nanotube supported ruthenium catalysts for the treatment of high strength wastewater with aniline using wet air oxidation. Carbon, 44(12), 2384-2391.

Gavaskar, A., Tatar, L., Condit, W. 2005. Cost and performance report nanoscale zero-valent iron technologies for source remediation. Naval Facilities Engineering Service Center. N47408-01D-8207.

Gil-Díaz, M., Alonso, J., Rodríguez-Valdés, E., Gallego, J.R., Lobo, M.C. 2017a. Comparing different commercial zero valent iron nanoparticles to immobilize $\mathrm{As}$ and $\mathrm{Hg}$ in brownfield soil. Science of The Total Environment, 584-585, 1324-1332.

Gil-Díaz, M., Diez-Pascual, S., González, A., Alonso, J., Rodríguez-Valdés, E., Gallego, J.R., Lobo, M.C. 2016a. A nanoremediation strategy for the recovery of an As-polluted soil. Chemosphere, 149, 137-145. 
Gil-Díaz, M., González, A., Alonso, J., Lobo, M.C. 2016b. Evaluation of the stability of a nanoremediation strategy using barley plants. Journal of Environmental Management, 165, $150-158$.

Gil-Díaz, M., Pinilla, P., Alonso, J., Lobo, M.C. 2017b. Viability of a nanoremediation process in single or multi-metal(loid) contaminated soils. Journal of Hazardous Materials, 321, 812-819.

Gollavelli, G., Chang, C.-C., Ling, Y.-C. 2013. Facile synthesis of smart magnetic graphene for safe drinking water: heavy metal removal and disinfection control. ACS Sustainable Chemistry \& Engineering, 1(5), 462-472.

Gomes, H.I., Fan, G., Mateus, E.P., Dias-Ferreira, C., Ribeiro, A.B. 2014. Assessment of combined electro-nanoremediation of molinate contaminated soil. Science of The Total Environment, 493, 178-184.

Guerra, F.D., Attia, M.F., Whitehead, D.C., Alexis, F. 2018. Nanotechnology for environmental remediation: materials and applications. Molecules, 23(7), 1760.

Guo, X., Yang, Z., Dong, H., Guan, X., Ren, Q., Lv, X., Jin, X. 2016. Simple combination of oxidants with zero-valent-iron (ZVI) achieved very rapid and highly efficient removal of heavy metals from water. Water Research, 88, 671-680.

Gupta, V.K., Moradi, O., Tyagi, I., Agarwal, S., Sadegh, H., Shahryari-Ghoshekandi, R., Makhlouf, A.S.H., Goodarzi, M., Garshasbi, A. 2016. Study on the removal of heavy metal ions from industry waste by carbon nanotubes: Effect of the surface modification: a review. Critical Reviews in Environmental Science and Technology, 46(2), 93-118.

Gusain, R., Kumar, N., Ray, S.S. 2020. Recent advances in carbon nanomaterial-based adsorbents for water purification. Coordination Chemistry Reviews, 405, 213111.

Han, Y., Shi, N., Wang, H., Pan, X., Fang, H., Yu, Y. 2016. Nanoscale zerovalent iron-mediated degradation of DDT in soil. Environmental Science and Pollution Research, 23(7), 6253-6263.

Hassan, K.H., Jarullah, A.A., Saadi, S.K. 2017. Synthesis of copper oxide nanoparticle as an adsorbent for removal of $\mathrm{Cd}(\mathrm{II})$ and $\mathrm{Ni}(\mathrm{II})$ ions from binary system. International Journal of Applied Environmental Sciences, 12, 1841-1861.

Hirthna, Sendhilnathan, S., Rajan, P.I., Adinaveen, T. 2018. Synthesis and characterization of $\mathrm{NiFe}_{2} \mathrm{O}_{4}$ nanoparticles for the enhancement of direct sunlight photocatalytic degradation of methyl orange. Journal of Superconductivity and Novel Magnetism, 31(10), 3315-3322.

Hjorth, R., Coutris, C., Nguyen, N.H.A., Sevcu, A., Gallego-Urrea, J.A., Baun, A., Joner, E.J. 2017. Ecotoxicity testing and environmental risk assessment of iron nanomaterials for sub-surface remediation - Recommendations from the FP7 project NanoRem. Chemosphere, 182, 525-531.

Hosseini, S.M., Tosco, T., Ataie-Ashtiani, B., Simmons, C.T. 2018. Non-pumping reactive wells filled with mixing nano and micro zero-valent iron for nitrate removal from groundwater: Vertical, horizontal, and slanted wells. Journal of Contaminant Hydrology, 210, 50-64.

Hou, D., O’Connor, D., Igalavithana, A.D., Alessi, D.S., Luo, J., Tsang, D.C.W., Sparks, D.L., Yamauchi, Y., Rinklebe, J., Ok, Y.S. 2020. Metal contamination and bioremediation of agricultural soils for food safety and sustainability. Nature Reviews Earth \& Environment, 1, 366-381.

Huang, D., Wang, X., Zhang, C., Zeng, G., Peng, Z., Zhou, J., Cheng, M., Wang, R., Hu, Z., Qin, X. 2017. Sorptive removal of ionizable antibiotic sulfamethazine from aqueous solution by graphene oxide-coated biochar nanocomposites: Influencing factors and mechanism. Chemosphere, 186, 414-421.

Inyang, M., Gao, B., Zimmerman, A., Zhou, Y., Cao, X. 2015. Sorption and cosorption of lead and sulfapyridine on carbon nanotube-modified biochars. Environmental Science and Pollution Research, 22(3), 1868-1876.

Isherwood, P.J.M. 2017. Copper zinc oxide: Investigation into a p-type mixed metal oxide system. Vacuum, 139, 173-177.

Jame, S.A., Zhou, Z. 2016. Electrochemical carbon nanotube filters for water and wastewater treatment. Nanotechnology Reviews, 5(1), 41-50.

Jiang, D., Zeng, G., Huang, D., Chen, M., Zhang, C., Huang, C., Wan, J. 2018. Remediation of contaminated soils by enhanced nanoscale zero valent iron. Environmental Research, 163, 217 227. 
Kamath, V., Chandra, P., Jeppu, G.P. 2020. Comparative study of using five different leaf extracts in the green synthesis of iron oxide nanoparticles for removal of arsenic from water. International Journal of Phytoremediation, 22(12), 1278-1294.

Kang, Y.-G., Yoon, H., Lee, W., Kim, E.-j., Chang, Y.-S. 2018. Comparative study of peroxide oxidants activated by nZVI: Removal of 1,4-Dioxane and arsenic(III) in contaminated waters. Chemical Engineering Journal, 334, 2511-2519.

Karn, B., Kuiken, T., Otto, M. 2009. Nanotechnology and in situ remediation: a review of the benefits and potential risks. Environmental Health Perspectives, 117(12), 1813-1831.

Kaur, Y., Bhatia, Y., Chaudhary, S., Chaudhary, G.R. 2017. Comparative performance of bare and functionalize $\mathrm{ZnO}$ nanoadsorbents for pesticide removal from aqueous solution. Journal of Molecular Liquids, 234, 94-103.

Khairy, M., Zakaria, W. 2014. Effect of metal-doping of $\mathrm{TiO}_{2}$ nanoparticles on their photocatalytic activities toward removal of organic dyes. Egyptian Journal of Petroleum, 23(4), 419-426.

Khalaj, M., Kamali, M., Khodaparast, Z., Jahanshahi, A. 2018. Copper-based nanomaterials for environmental decontamination - An overview on technical and toxicological aspects. Ecotoxicology and Environmental Safety, 148, 813-824.

Khan, I., Saeed, K., Khan, I. 2019. Nanoparticles: Properties, applications and toxicities. Arabian Journal of Chemistry, 12(7), 908-931.

Kim, Y.-M., Murugesan, K., Chang, Y.-Y., Kim, E.-J., Chang, Y.-S. 2012. Degradation of polybrominated diphenyl ethers by a sequential treatment with nanoscale zero valent iron and aerobic biodegradation. Journal of Chemical Technology \& Biotechnology, 87(2), 216-224.

Kirankumar, V.S., Sumathi, S. 2017. Catalytic activity of bismuth doped zinc aluminate nanoparticles towards environmental remediation. Materials Research Bulletin, 93, 74-82.

Kopittke, P.M., Lombi, E., Wang, P., Schjoerring, J.K., Husted, S. 2019. Nanomaterials as fertilizers for improving plant mineral nutrition and environmental outcomes. Environmental Science: Nano, 6(12), 3513-3524.

Körösi, L., Prato, M., Scarpellini, A., Kovács, J., Dömötör, D., Kovács, T., Papp, S. 2016. $\mathrm{H}_{2} \mathrm{O}_{2}$-assisted photocatalysis on flower-like rutile $\mathrm{TiO} 2$ nanostructures: Rapid dye degradation and inactivation of bacteria. Applied Surface Science, 365, 171-179.

Kotchaplai, P., Khan, E., Vangnai, A.S. 2017. Membrane alterations in Pseudomonas putida F1 exposed to nanoscale zerovalent iron: effects of short-term and repetitive nZVI exposure. Environmental Science \& Technology, 51(14), 7804-7813.

Krasucka, P., Pan, B., Sik Ok, Y., Mohan, D., Sarkar, B., Oleszczuk, P. 2021. Engineered biochar - A sustainable solution for the removal of antibiotics from water. Chemical Engineering Journal, 405, 126926.

Krishnaswamy, K., Orsat, V. 2017. Chapter 2 - Sustainable Delivery Systems Through Green Nanotechnology. in: Nano- and Microscale Drug Delivery Systems, (Ed.) A.M. Grumezescu, Elsevier, pp. 17-32.

Kumar, A., Sharma, G., Naushad, M., Al-Muhtaseb, A.a.H., García-Peñas, A., Mola, G.T., Si, C., Stadler, F.J. 2020a. Bio-inspired and biomaterials-based hybrid photocatalysts for environmental detoxification: A review. Chemical Engineering Journal, 382, 122937.

Kumar, N., Chaurand, P., Rose, J., Diels, L., Bastiaens, L. 2015. Synergistic effects of sulfate reducing bacteria and zero valent iron on zinc removal and stability in aquifer sediment. Chemical Engineering Journal, 260, 83-89.

Kumar, V., Lee, Y.-S., Shin, J.-W., Kim, K.-H., Kukkar, D., Fai Tsang, Y. 2020b. Potential applications of graphene-based nanomaterials as adsorbent for removal of volatile organic compounds. Environment International, 135, 105356.

Lazaratou, C.V., Vayenas, D.V., Papoulis, D. 2020. The role of clays, clay minerals and clay-based materials for nitrate removal from water systems: A review. Applied Clay Science, 185, 105377.

Le, T.T., Nguyen, K.-H., Jeon, J.-R., Francis, A.J., Chang, Y.-S. 2015. Nano/bio treatment of polychlorinated biphenyls with evaluation of comparative toxicity. Journal of Hazardous Materials, 287, 335-341.

Le, T.T.A., McEvoy, J., Khan, E. 2016. Mitigation of bactericidal effect of carbon nanotubes by cell entrapment. Science of The Total Environment, 565, 787-794. 
Lee, K.M., Wong, C.P.P., Tan, T.L., Lai, C.W. 2018. Functionalized carbon nanotubes for adsorptive removal of water pollutants. Materials Science and Engineering: B, 236-237, 61-69.

Lefevre, E., Bossa, N., Wiesner, M.R., Gunsch, C.K. 2016. A review of the environmental implications of in situ remediation by nanoscale zero valent iron (nZVI): Behavior, transport and impacts on microbial communities. Science of The Total Environment, 565, 889-901.

Lei, C., Sun, Y., Khan, E., Chen, S.S., Tsang, D.C.W., Graham, N.J.D., Ok, Y.S., Yang, X., Lin, D., Feng, Y., Li, X.-D. 2018. Removal of chlorinated organic solvents from hydraulic fracturing wastewater by bare and entrapped nanoscale zero-valent iron. Chemosphere, 196, 9-17.

Lellis, B., Fávaro-Polonio, C.Z., Pamphile, J.A., Polonio, J.C. 2019. Effects of textile dyes on health and the environment and bioremediation potential of living organisms. Biotechnology Research and Innovation, 3(2), 275-290.

Lewis, R.W., Bertsch, P.M., McNear, D.H. 2019. Nanotoxicity of engineered nanomaterials (ENMs) to environmentally relevant beneficial soil bacteria - a critical review. Nanotoxicology, 13(3), 392-428.

Li, D., Li, B., Wang, Q., Hou, N., Li, C., Cheng, X. 2016. Toxicity of $\mathrm{TiO}_{2}$ nanoparticle to denitrifying strain CFY1 and the impact on microbial community structures in activated sludge. Chemosphere, 144, 1334-1341.

Li, F., Chen, J., Hu, X., He, F., Bean, E., Tsang, D.C.W., Ok, Y.S., Gao, B. 2020. Applications of carbonaceous adsorbents in the remediation of polycyclic aromatic hydrocarbon-contaminated sediments: A review. Journal of Cleaner Production, 255, 120263.

Li, H., Qiu, Y.-f., Wang, X.-1., Yang, J., Yu, Y.-j., Chen, Y.-q., Liu, Y.-d. 2017. Biochar supported $\mathrm{Ni} / \mathrm{Fe}$ bimetallic nanoparticles to remove 1,1,1-trichloroethane under various reaction conditions. Chemosphere, 169, 534-541.

Li, R., Gao, Y., Jin, X., Chen, Z., Megharaj, M., Naidu, R. 2015. Fenton-like oxidation of 2,4-DCP in aqueous solution using iron-based nanoparticles as the heterogeneous catalyst. Journal of Colloid and Interface Science, 438, 87-93.

Li, Y., Zhang, Y., Li, J., Sheng, G., Zheng, X. 2013. Enhanced reduction of chlorophenols by nanoscale zerovalent iron supported on organobentonite. Chemosphere, 92(4), 368-374.

Li, Z., Wang, L., Meng, J., Liu, X., Xu, J., Wang, F., Brookes, P. 2018. Zeolite-supported nanoscale zero-valent iron: New findings on simultaneous adsorption of $\mathrm{Cd}(\mathrm{II}), \mathrm{Pb}(\mathrm{II})$, and $\mathrm{As}(\mathrm{III})$ in aqueous solution and soil. Journal of Hazardous Materials, 344, 1-11.

Lin, K.-S., Mdlovu, N.V., Chen, C.-Y., Chiang, C.-L., Dehvari, K. 2018. Degradation of TCE, PCE, and 1,2-DCE DNAPLs in contaminated groundwater using polyethylenimine-modified zerovalent iron nanoparticles. Journal of Cleaner Production, 175, 456-466.

Lin, Z., Weng, X., Ma, L., Sarkar, B., Chen, Z. 2019. Mechanistic insights into Pb(II) removal from aqueous solution by green reduced graphene oxide. Journal of Colloid and Interface Science, 550, 1-9.

Liu, J., Jiang, J., Meng, Y., Aihemaiti, A., Xu, Y., Xiang, H., Gao, Y., Chen, X. 2020. Preparation, environmental application and prospect of biochar-supported metal nanoparticles: A review. Journal of Hazardous Materials, 388, 122026.

Liu, J., Ma, Y., Xu, T., Shao, G. 2010. Preparation of zwitterionic hybrid polymer and its application for the removal of heavy metal ions from water. Journal of Hazardous Materials, 178(1), 10211029.

Liu, Y., Xie, J., Ong, C.N., Vecitis, C.D., Zhou, Z. 2015. Electrochemical wastewater treatment with carbon nanotube filters coupled with in situ generated $\mathrm{H}_{2} \mathrm{O}_{2}$. Environmental Science: Water Research \& Technology, 1(6), 769-778.

Lu, S.-y., Wu, D., Wang, Q.-1., Yan, J., Buekens, A.G., Cen, K.-f. 2011. Photocatalytic decomposition on nano-TiO2: Destruction of chloroaromatic compounds. Chemosphere, 82(9), 1215-1224.

Ma, J., Ping, D., Dong, X. 2017. Recent Developments of Graphene Oxide-Based Membranes: A Review. Membranes, 7(3), 52.

Mackenzie, K., Bleyl, S., Georgi, A., Kopinke, F.-D. 2012. Carbo-Iron - An Fe/AC composite - As alternative to nano-iron for groundwater treatment. Water Research, 46(12), 3817-3826.

Mackenzie, K., Bleyl, S., Kopinke, F.-D., Doose, H., Bruns, J. 2016. Carbo-Iron as improvement of the nanoiron technology: From laboratory design to the field test. Science of The Total Environment, 563-564, 641-648. 
Majumder, A., Ramrakhiani, L., Mukherjee, D., Mishra, U., Halder, A., Mandal, A.K., Ghosh, S. 2019. Green synthesis of iron oxide nanoparticles for arsenic remediation in water and sludge utilization. Clean Technologies and Environmental Policy, 21(4), 795-813.

Mandal, S., Sarkar, B., Mukhopadhyay, R., Biswas, J.K., Manjaiah, K.M. 2018. MicroparticleSupported Nanocomposites for Safe Environmental Applications. in: Nanomaterials: Ecotoxicity, Safety, and Public Perception, (Eds.) M. Rai, J.K. Biswas, Springer International Publishing. Cham, pp. 305-317.

Matos, M.P.S.R., Correia, A.A.S., Rasteiro, M.G. 2017. Application of carbon nanotubes to immobilize heavy metals in contaminated soils. Journal of Nanoparticle Research, 19(4), 126.

Meeks, N.D., Smuleac, V., Stevens, C., Bhattacharyya, D. 2012. Iron-based nanoparticles for toxic organic degradation: silica platform and green synthesis. Industrial \& Engineering Chemistry Research, 51(28), 9581-9590.

Mehta, D., Mazumdar, S., Singh, S.K. 2015. Magnetic adsorbents for the treatment of water/wastewater-A review. Journal of Water Process Engineering, 7, 244-265.

Meyer, J.C., Geim, A.K., Katsnelson, M.I., Novoselov, K.S., Booth, T.J., Roth, S. 2007. The structure of suspended graphene sheets. Nature, 446(7131), 60-63.

Meyer, M.F., Powers, S.M., Hampton, S.E. 2019. An evidence synthesis of pharmaceuticals and personal care products (PPCPs) in the environment: imbalances among compounds, sewage treatment techniques, and ecosystem types. Environmental Science \& Technology, 53(22), 12961-12973.

Mines, P.D., Uthuppu, B., Thirion, D., Jakobsen, M.H., Yavuz, C.T., Andersen, H.R., Hwang, Y. 2018. Granular activated carbon with grafted nanoporous polymer enhances nanoscale zero-valent iron impregnation and water contaminant removal. Chemical Engineering Journal, 339, 22-31.

Moschini, E., Gualtieri, M., Colombo, M., Fascio, U., Camatini, M., Mantecca, P. 2013. The modality of cell-particle interactions drives the toxicity of nanosized $\mathrm{CuO}$ and $\mathrm{TiO}_{2}$ in human alveolar epithelial cells. Toxicology Letters, 222(2), 102-116.

Mukhopadhyay, R., Bhaduri, D., Sarkar, B., Rusmin, R., Hou, D., Khanam, R., Sarkar, S., Kumar Biswas, J., Vithanage, M., Bhatnagar, A., Ok, Y.S. 2020. Clay-polymer nanocomposites: Progress and challenges for use in sustainable water treatment. Journal of Hazardous Materials, 383, 121125.

Murugadas, A., Zeeshan, M., Thamaraiselvi, K., Ghaskadbi, S., Akbarsha, M.A. 2016. Hydra as a model organism to decipher the toxic effects of copper oxide nanorod: Eco-toxicogenomics approach. Scientific Reports, 6(1), 29663.

Nathanail, C.P., Bakker, L.M.M., Bardos, P., Furukawa, Y., Nardella, A., Smith, G., Smith, J.W.N., Goetsche, G. 2017. Towards an international standard: The ISO/DIS 18504 standard on sustainable remediation. Remediation Journal, 28(1), 9-15.

Nathanail, C.P., Bardos, R.P. 2004. Risk Management. in: Reclamation of Contaminated Land, (Eds.) C.P. Nathanail, R.P. Bardos, John Wiley \& Sons Ltd. Chichester, UK, pp. 109-124.

Němeček, J., Lhotský, O., Cajthaml, T. 2014. Nanoscale zero-valent iron application for in situ reduction of hexavalent chromium and its effects on indigenous microorganism populations. Science of The Total Environment, 485-486, 739-747.

Olabarrieta, J., Monzón, O., Belaustegui, Y., Alvarez, J.-I., Zorita, S. 2018. Removal of $\mathrm{TiO}_{2}$ nanoparticles from water by low pressure pilot plant filtration. Science of The Total Environment, 618, 551-560.

Pan, Y., Zhou, M., Li, X., Xu, L., Tang, Z., Sheng, X., Li, B. 2017. Highly efficient persulfate oxidation process activated with pre-magnetization Fe0. Chemical Engineering Journal, 318, 50-56.

Parham, H., Zargar, B., Shiralipour, R. 2012. Fast and efficient removal of mercury from water samples using magnetic iron oxide nanoparticles modified with 2-mercaptobenzothiazole. Journal of Hazardous Materials, 205-206, 94-100.

Pasinszki, T., Krebsz, M. 2020. Synthesis and application of zero-valent iron nanoparticles in water treatment, environmental remediation, catalysis, and their biological effects. Nanomaterials, $\mathbf{1 0}(5), 917$.

Patil, S.S., Shedbalkar, U.U., Truskewycz, A., Chopade, B.A., Ball, A.S. 2016. Nanoparticles for environmental clean-up: A review of potential risks and emerging solutions. Environmental Technology \& Innovation, 5, 10-21. 
Peeters, K., Lespes, G., Zuliani, T., Ščančar, J., Milačič, R. 2016. The fate of iron nanoparticles in environmental waters treated with nanoscale zero-valent iron, FeONPs and $\mathrm{Fe}_{3} \mathrm{O}_{4} \mathrm{NPs}_{\text {. Water }}$ Research, 94, 315-327.

Pei, Z., Li, L., Sun, L., Zhang, S., Shan, X.-q., Yang, S., Wen, B. 2013. Adsorption characteristics of 1,2,4-trichlorobenzene, 2,4,6-trichlorophenol, 2-naphthol and naphthalene on graphene and graphene oxide. Carbon, 51, 156-163.

Perreault, F., Fonseca de Faria, A., Elimelech, M. 2015. Environmental applications of graphene-based nanomaterials. Chemical Society Reviews, 44(16), 5861-5896.

Perreault, F., Popovic, R., Dewez, D. 2014. Different toxicity mechanisms between bare and polymercoated copper oxide nanoparticles in Lemna gibba. Environmental Pollution, 185, 219-227.

Premarathna, K.S.D., Rajapaksha, A.U., Sarkar, B., Kwon, E.E., Bhatnagar, A., Ok, Y.S., Vithanage, M. 2019. Biochar-based engineered composites for sorptive decontamination of water: A review. Chemical Engineering Journal, 372, 536-550.

Qi, J., Zhao, K., Li, G., Gao, Y., Zhao, H., Yu, R., Tang, Z. 2014. Multi-shelled $\mathrm{CeO}_{2}$ hollow microspheres as superior photocatalysts for water oxidation. Nanoscale, 6(8), 4072-4077.

Qiao, Y., Wu, J., Xu, Y., Fang, Z., Zheng, L., Cheng, W., Tsang, E.P., Fang, J., Zhao, D. 2017. Remediation of cadmium in soil by biochar-supported iron phosphate nanoparticles. Ecological Engineering, 106, 515-522.

Quan, G., Kong, L., Lan, Y., Yan, J., Gao, B. 2018. Removal of acid orange 7 by surfactant-modified iron nanoparticle supported on palygorskite: Reactivity and mechanism. Applied Clay Science, 152, 173-182.

Quinn, J., Geiger, C., Clausen, C., Brooks, K., Coon, C., O'Hara, S., Krug, T., Major, D., Yoon, W.-S., Gavaskar, A., Holdsworth, T. 2005. Field demonstration of DNAPL dehalogenation using emulsified zero-valent iron. Environmental Science \& Technology, 39(5), 1309-1318.

Rai, M., Biswas, J.K. 2018. Nanomaterials: Ecotoxicity, Safety and Public Perception. Springer Nature, Switzerland.

Rai, P.K., Kumar, V., Lee, S., Raza, N., Kim, K.-H., Ok, Y.S., Tsang, D.C.W. 2018. Nanoparticle-plant interaction: Implications in energy, environment, and agriculture. Environment International, 119, 1-19.

Raizada, P., Sudhaik, A., Singh, P. 2019. Photocatalytic water decontamination using graphene and $\mathrm{ZnO}$ coupled photocatalysts: A review. Materials Science for Energy Technologies, 2(3), 509525.

Ramesha, G.K., Vijaya Kumara, A., Muralidhara, H.B., Sampath, S. 2011. Graphene and graphene oxide as effective adsorbents toward anionic and cationic dyes. Journal of Colloid and Interface Science, 361(1), 270-277.

Rengaraj, S., Venkataraj, S., Yeon, J.-W., Kim, Y., Li, X.Z., Pang, G.K.H. 2007. Preparation, characterization and application of $\mathrm{Nd}-\mathrm{TiO} 2$ photocatalyst for the reduction of $\mathrm{Cr}(\mathrm{VI})$ under UV light illumination. Applied Catalysis B: Environmental, 77(1), 157-165.

Rizwan, M., Ali, S., Qayyum, M.F., Ok, Y.S., Adrees, M., Ibrahim, M., Zia-ur-Rehman, M., Farid, M., Abbas, F. 2017. Effect of metal and metal oxide nanoparticles on growth and physiology of globally important food crops: A critical review. Journal of Hazardous Materials, 322, 2-16.

Rusmin, R., Sarkar, B., Tsuzuki, T., Kawashima, N., Naidu, R. 2017. Removal of lead from aqueous solution using superparamagnetic palygorskite nanocomposite: Material characterization and regeneration studies. Chemosphere, 186, 1006-1015.

Sadegh, H., Ali, G.A.M., Gupta, V.K., Makhlouf, A.S.H., Shahryari-ghoshekandi, R., Nadagouda, M.N., Sillanpää, M., Megiel, E. 2017. The role of nanomaterials as effective adsorbents and their applications in wastewater treatment. Journal of Nanostructure in Chemistry, 7(1), 1-14.

Sadegh, H., Zare, K., Maazinejad, B., Shahryari-ghoshekandi, R., Tyagi, I., Agarwal, S., Gupta, V.K. 2016. Synthesis of MWCNT-COOH-Cysteamine composite and its application for dye removal. Journal of Molecular Liquids, 215, 221-228.

Safavi, A., Maleki, N., Doroodmand, M.M. 2010. Fabrication of a selective mercury sensor based on the adsorption of cold vapor of mercury on carbon nanotubes: Determination of mercury in industrial wastewater. Journal of Hazardous Materials, 173(1), 622-629.

Saharan, P., Chaudhary, G.R., Mehta, S.K., Umar, A. 2014. Removal of water contaminants by iron oxide nanomaterials. Journal of Nanoscience and Nanotechnology, 14(1), 627-643. 
Saheed, I.O., Da, O.W., Suah, F.B.M. 2021. Chitosan modifications for adsorption of pollutants - a review. Journal of Hazardous Materials, 408, 124889.

Salam, J.A., Das, N. 2015. Degradation of lindane by a novel embedded bio-nano hybrid system in aqueous environment. Applied Microbiology and Biotechnology, 99(5), 2351-2360.

Sarkar, B., Liu, E., McClure, S., Sundaramurthy, J., Srinivasan, M., Naidu, R. 2015. Biomass derived palygorskite-carbon nanocomposites: Synthesis, characterisation and affinity to dye compounds. Applied Clay Science, 114, 617-626.

Sarkar, B., Mandal, S., Tsang, Y.F., Kumar, P., Kim, K.-H., Ok, Y.S. 2018. Designer carbon nanotubes for contaminant removal in water and wastewater: A critical review. Science of The Total Environment, 612, 561-581.

Scaria, J., Nidheesh, P.V., Kumar, M.S. 2020. Synthesis and applications of various bimetallic nanomaterials in water and wastewater treatment. Journal of Environmental Management, 259, 110011.

Schaefer, D.W., Justice, R.S. 2007. How nano are nanocomposites? Macromolecules, 40(24), 85018517.

Schaefer, H.R., Dennis, S., Fitzpatrick, S. 2020. Cadmium: Mitigation strategies to reduce dietary exposure. Journal of Food Science, 85(2), 260-267.

Sepúlveda, P., Rubio, M.A., Baltazar, S.E., Rojas-Nunez, J., Sánchez Llamazares, J.L., Garcia, A.G., Arancibia-Miranda, N. 2018. As(V) removal capacity of $\mathrm{FeCu}$ bimetallic nanoparticles in aqueous solutions: The influence of $\mathrm{Cu}$ content and morphologic changes in bimetallic nanoparticles. Journal of Colloid and Interface Science, 524, 177-187.

Shanbhogue, S.S., Bezbaruah, A., Simsek, S., Khan, E. 2017. Trichloroethene removal by separately encapsulated and co-encapsulated bacterial degraders and nanoscale zero-valent iron. International Biodeterioration \& Biodegradation, 125, 269-276.

Sheu, Y.T., Lien, P.J., Chen, K.F., Ou, J.H., Kao, C.M. 2016. Application of NZVI-contained emulsified substrate to bioremediate PCE-contaminated groundwater - A pilot-scale study. Chemical Engineering Journal, 304, 714-727.

Sievers, C., Noda, Y., Qi, L., Albuquerque, E.M., Rioux, R.M., Scott, S.L. 2016. Phenomena affecting catalytic reactions at solid-liquid interfaces. ACS Catalysis, 6(12), 8286-8307.

Singh, R., Manickam, N., Mudiam, M.K.R., Murthy, R.C., Misra, V. 2013. An integrated (nano-bio) technique for degradation of $\gamma-\mathrm{HCH}$ contaminated soil. Journal of Hazardous Materials, 258259, 35-41.

Singh, R., Misra, V., Mudiam, M.K.R., Chauhan, L.K.S., Singh, R.P. 2012a. Degradation of $\gamma$-HCH spiked soil using stabilized $\mathrm{Pd} / \mathrm{Fe}^{0}$ bimetallic nanoparticles: Pathways, kinetics and effect of reaction conditions. Journal of Hazardous Materials, 237-238, 355-364.

Singh, R., Misra, V., Singh, R.P. 2012b. Removal of Cr(VI) by nanoscale zero-valent iron (nZVI) from soil contaminated with tannery wastes. Bulletin of Environmental Contamination and Toxicology, 88(2), 210-214.

Soliemanzadeh, A., Fekri, M. 2017. The application of green tea extract to prepare bentonite-supported nanoscale zero-valent iron and its performance on removal of $\mathrm{Cr}(\mathrm{VI})$ : Effect of relative parameters and soil experiments. Microporous and Mesoporous Materials, 239, 60-69.

Stefaniuk, M., Oleszczuk, P., Ok, Y.S. 2016. Review on nano zerovalent iron (nZVI): From synthesis to environmental applications. Chemical Engineering Journal, 287, 618-632.

Su, Y.-f., Hsu, C.-Y., Shih, Y.-h. 2012. Effects of various ions on the dechlorination kinetics of hexachlorobenzene by nanoscale zero-valent iron. Chemosphere, 88(11), 1346-1352.

Suazo-Hernández, J., Sepúlveda, P., Manquián-Cerda, K., Ramírez-Tagle, R., Rubio, M.A., Bolan, N., Sarkar, B., Arancibia-Miranda, N. 2019. Synthesis and characterization of zeolite-based composites functionalized with nanoscale zero-valent iron for removing arsenic in the presence of selenium from water. Journal of Hazardous Materials, 373, 810-819.

Sun, Y., Lei, C., Khan, E., Chen, S.S., Tsang, D.C.W., Ok, Y.S., Lin, D., Feng, Y., Li, X.-d. 2018. Aging effects on chemical transformation and metal(loid) removal by entrapped nanoscale zero-valent iron for hydraulic fracturing wastewater treatment. Science of The Total Environment, 615, 498-507. 
Tafazoli, M., Hojjati, S.M., Biparva, P., Kooch, Y., Lamersdorf, N. 2017. Reduction of soil heavy metal bioavailability by nanoparticles and cellulosic wastes improved the biomass of tree seedlings. Journal of Plant Nutrition and Soil Science, 180(6), 683-693.

Tanzifi, M., Hosseini, S.H., Kiadehi, A.D., Olazar, M., Karimipour, K., Rezaiemehr, R., Ali, I. 2017. Artificial neural network optimization for methyl orange adsorption onto polyaniline nanoadsorbent: Kinetic, isotherm and thermodynamic studies. Journal of Molecular Liquids, 244, 189-200.

Tasharrofi, S., Rouzitalab, Z., Maklavany, D.M., Esmaeili, A., Rabieezadeh, M., Askarieh, M., Rashidi, A., Taghdisian, H. 2020. Adsorption of cadmium using modified zeolite-supported nanoscale zero-valent iron composites as a reactive material for PRBs. Science of The Total Environment, 736, 139570.

Tiberg, C., Kumpiene, J., Gustafsson, J.P., Marsz, A., Persson, I., Mench, M., Kleja, D.B. 2016. Immobilization of $\mathrm{Cu}$ and $\mathrm{As}$ in two contaminated soils with zero-valent iron - Long-term performance and mechanisms. Applied Geochemistry, 67, 144-152.

Uddin, M.K. 2017. A review on the adsorption of heavy metals by clay minerals, with special focus on the past decade. Chemical Engineering Journal, 308, 438-462.

UN. 2016. The Sustainable Development Goals Report 2016. United Nations.

Varadhi, S.N., Gill, H., Apoldo, L.J., Liao, K., Blackman, R.A., Wittman, W.K. 2005. Full-scale nanoiron injection for treatment of groundwater contaminated with chlorinated hydrocarbons. in: Natural Gas Technologies Conference. Orlando, FL.

Vidovix, T.B., Quesada, H.B., Januário, E.F.D., Bergamasco, R., Vieira, A.M.S. 2019. Green synthesis of copper oxide nanoparticles using Punica granatum leaf extract applied to the removal of methylene blue. Materials Letters, 257, 126685.

Vítková, M., Rákosová, S., Michálková, Z., Komárek, M. 2017. Metal(loid)s behaviour in soils amended with nano zero-valent iron as a function of $\mathrm{pH}$ and time. Journal of Environmental Management, 186, 268-276.

Vogel, M., Nijenhuis, I., Lloyd, J., Boothman, C., Pöritz, M., Mackenzie, K. 2018. Combined chemical and microbiological degradation of tetrachloroethene during the application of Carbo-Iron at a contaminated field site. Science of The Total Environment, 628-629, 1027-1036.

Vojoudi, H., Badiei, A., Bahar, S., Mohammadi Ziarani, G., Faridbod, F., Ganjali, M.R. 2017. A new nano-sorbent for fast and efficient removal of heavy metals from aqueous solutions based on modification of magnetic mesoporous silica nanospheres. Journal of Magnetism and Magnetic Materials, 441, 193-203.

Wang, H., Kim, B., Wunder, S.L. 2015a. Nanoparticle-supported lipid bilayers as an in situ remediation strategy for hydrophobic organic contaminants in soils. Environmental Science \& Technology, 49(1), 529-536.

Wang, J., Chen, B. 2015. Adsorption and coadsorption of organic pollutants and a heavy metal by graphene oxide and reduced graphene materials. Chemical Engineering Journal, 281, 379-388.

Wang, M., Hossain, F., Sulaiman, R., Ren, X. 2019. Exposure to inorganic arsenic and lead and autism spectrum disorder in children: a systematic review and meta-analysis. Chemical Research in Toxicology, 32(10), 1904-1919.

Wang, P., Lombi, E., Menzies, N.W., Zhao, F.-J., Kopittke, P.M. 2018. Engineered silver nanoparticles in terrestrial environments: a meta-analysis shows that the overall environmental risk is small. Environmental Science: Nano, 5(11), 2531-2544.

Wang, X., Wang, P., Ma, J., Liu, H., Ning, P. 2015b. Synthesis, characterization, and reactivity of cellulose modified nano zero-valent iron for dye discoloration. Applied Surface Science, $\mathbf{3 4 5}$, 57-66.

Wang, X., Zhang, D., Pan, X., Lee, D.-J., Al-Misned, F.A., Mortuza, M.G., Gadd, G.M. 2017. Aerobic and anaerobic biosynthesis of nano-selenium for remediation of mercury contaminated soil. Chemosphere, 170, 266-273.

Wang, Z., Xu, L., Zhao, J., Wang, X., White, J.C., Xing, B. 2016. CuO Nanoparticle interaction with Arabidopsis thaliana: toxicity, parent-progeny transfer, and gene expression. Environmental Science \& Technology, 50(11), 6008-6016. 
Weil, M., Mackenzie, K., Foit, K., Kühnel, D., Busch, W., Bundschuh, M., Schulz, R., Duis, K. 2019. Environmental risk or benefit? Comprehensive risk assessment of groundwater treated with nano Fe0-based Carbo-Iron ${ }^{\circledR}$. Science of The Total Environment, 677, 156-166.

Weil, M., Meißner, T., Springer, A., Bundschuh, M., Hübler, L., Schulz, R., Duis, K. 2016. Oxidized Carbo-Iron causes reduced reproduction and lower tolerance of juveniles in the amphipod Hyalella azteca. Aquatic Toxicology, 181, 94-103.

Wen, X.-J., Niu, C.-G., Guo, H., Zhang, L., Liang, C., Zeng, G.-M. 2018. Photocatalytic degradation of levofloxacin by ternary $\mathrm{Ag}_{2} \mathrm{CO}_{3} / \mathrm{CeO}_{2} / \mathrm{AgBr}$ photocatalyst under visible-light irradiation: degradation pathways, mineralization ability, and an accelerated interfacial charge transfer process study. Journal of Catalysis, 358, 211-223.

Wu, J., Xie, Y., Fang, Z., Cheng, W., Tsang, P.E. 2016a. Effects of Ni/Fe bimetallic nanoparticles on phytotoxicity and translocation of polybrominated diphenyl ethers in contaminated soil. Chemosphere, 162, 235-242.

Wu, J., Yi, Y., Li, Y., Fang, Z., Tsang, E.P. 2016b. Excellently reactive Ni/Fe bimetallic catalyst supported by biochar for the remediation of decabromodiphenyl contaminated soil: reactivity, mechanism, pathways and reducing secondary risks. Journal of Hazardous Materials, 320, 341-349.

Xie, W., Liang, Q., Qian, T., Zhao, D. 2015. Immobilization of selenite in soil and groundwater using stabilized Fe-Mn binary oxide nanoparticles. Water Research, 70, 485-494.

Xiong, T., Yuan, X., Wang, H., Leng, L., Li, H., Wu, Z., Jiang, L., Xu, R., Zeng, G. 2018a. Implication of graphene oxide in Cd-contaminated soil: A case study of bacterial communities. Journal of Environmental Management, 205, 99-106.

Xiong, Z., Lai, B., Yang, P. 2018b. Enhancing the efficiency of zero valent iron by electrolysis: Performance and reaction mechanism. Chemosphere, 194, 189-199.

Xu, G., Wang, J., Lu, M. 2014. Complete debromination of decabromodiphenyl ether using the integration of Dehalococcoides sp. strain CBDB1 and zero-valent iron. Chemosphere, 117, 455-461.

Yang, Z., Fang, Z., Tsang, P.E., Fang, J., Zhao, D. 2016a. In situ remediation and phytotoxicity assessment of lead-contaminated soil by biochar-supported nHAP. Journal of Environmental Management, 182, 247-251.

Yang, Z., Fang, Z., Zheng, L., Cheng, W., Tsang, P.E., Fang, J., Zhao, D. 2016b. Remediation of lead contaminated soil by biochar-supported nano-hydroxyapatite. Ecotoxicology and Environmental Safety, 132, 224-230.

Yi, Z.-j., Lian, B., Yang, Y.-q., Zou, J.-1. 2009. Treatment of simulated wastewater from in situ leaching uranium mining by zerovalent iron and sulfate reducing bacteria. Transactions of Nonferrous Metals Society of China, 19, s840-s844.

Zaleska-Medynska, A., Marchelek, M., Diak, M., Grabowska, E. 2016. Noble metal-based bimetallic nanoparticles: the effect of the structure on the optical, catalytic and photocatalytic properties. Advances in Colloid and Interface Science, 229, 80-107.

Zhang, W., Li, G., Wang, W., Qin, Y., An, T., Xiao, X., Choi, W. 2018a. Enhanced photocatalytic mechanism of $\mathrm{Ag}_{3} \mathrm{PO}_{4}$ nano-sheets using MS2 $(\mathrm{M}=\mathrm{Mo}, \mathrm{W}) / \mathrm{rGO}$ hybrids as co-catalysts for 4nitrophenol degradation in water. Applied Catalysis B: Environmental, 232, 11-18.

Zhang, W., Lo, I.M.C., Hu, L., Voon, C.P., Lim, B.L., Versaw, W.K. 2018b. Environmental risks of nano zerovalent iron for arsenate remediation: impacts on cytosolic levels of inorganic phosphate and MgATP2- in Arabidopsis thaliana. Environmental Science \& Technology, 52(7), 4385-4392.

Zhao, X., Lv, L., Pan, B., Zhang, W., Zhang, S., Zhang, Q. 2011. Polymer-supported nanocomposites for environmental application: A review. Chemical Engineering Journal, 170(2), 381-394.

Zhou, Y., Apul, O.G., Karanfil, T. 2015. Adsorption of halogenated aliphatic contaminants by graphene nanomaterials. Water Research, 79, 57-67.

Zhou, Y., Gao, B., Zimmerman, A.R., Chen, H., Zhang, M., Cao, X. 2014. Biochar-supported zerovalent iron for removal of various contaminants from aqueous solutions. Bioresource Technology, 152, 538-542. 
Zhou, Z., Ruan, W., Huang, H., Shen, C., Yuan, B., Huang, C.-H. 2016. Fabrication and characterization of $\mathrm{Fe} / \mathrm{Ni}$ nanoparticles supported by polystyrene resin for trichloroethylene degradation. Chemical Engineering Journal, 283, 730-739.

Zhu, F., Li, L., Ma, S., Shang, Z. 2016. Effect factors, kinetics and thermodynamics of remediation in the chromium contaminated soils by nanoscale zero valent $\mathrm{Fe} / \mathrm{Cu}$ bimetallic particles. Chemical Engineering Journal, 302, 663-669.

Zhu, F., Li, L., Ren, W., Deng, X., Liu, T. 2017a. Effect of pH, temperature, humic acid and coexisting anions on reduction of $\mathrm{Cr}(\mathrm{VI})$ in the soil leachate by $\mathrm{nZVI} / \mathrm{Ni}$ bimetal material. Environmental Pollution, 227, 444-450.

Zhu, S., Ho, S.-H., Huang, X., Wang, D., Yang, F., Wang, L., Wang, C., Cao, X., Ma, F. 2017b. Magnetic nanoscale zerovalent iron assisted biochar: interfacial chemical behaviors and heavy metals remediation performance. ACS Sustainable Chemistry \& Engineering, 5(11), 96739682.

Zhu, S., Huang, X., Wang, D., Wang, L., Ma, F. 2018. Enhanced hexavalent chromium removal performance and stabilization by magnetic iron nanoparticles assisted biochar in aqueous solution: Mechanisms and application potential. Chemosphere, 207, 50-59.

Zou, Y., Wang, X., Khan, A., Wang, P., Liu, Y., Alsaedi, A., Hayat, T., Wang, X. 2016. Environmental remediation and application of nanoscale zero-valent iron and its composites for the removal of heavy metal ions: a review. Environmental Science \& Technology, 50(14), 7290-7304. 


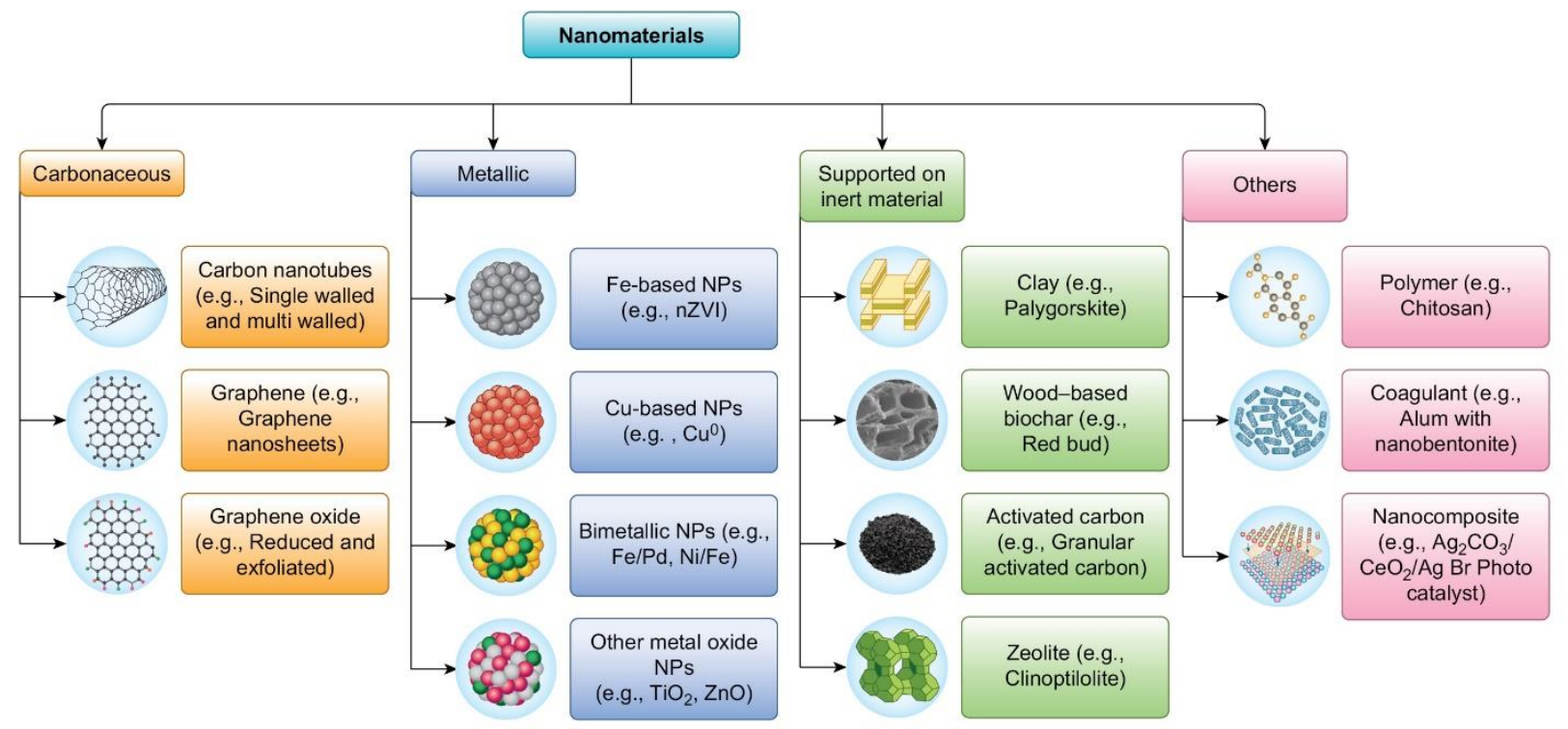

1667 Fig. 1. Types of nanomaterials used for the removal of environmental contaminants. 


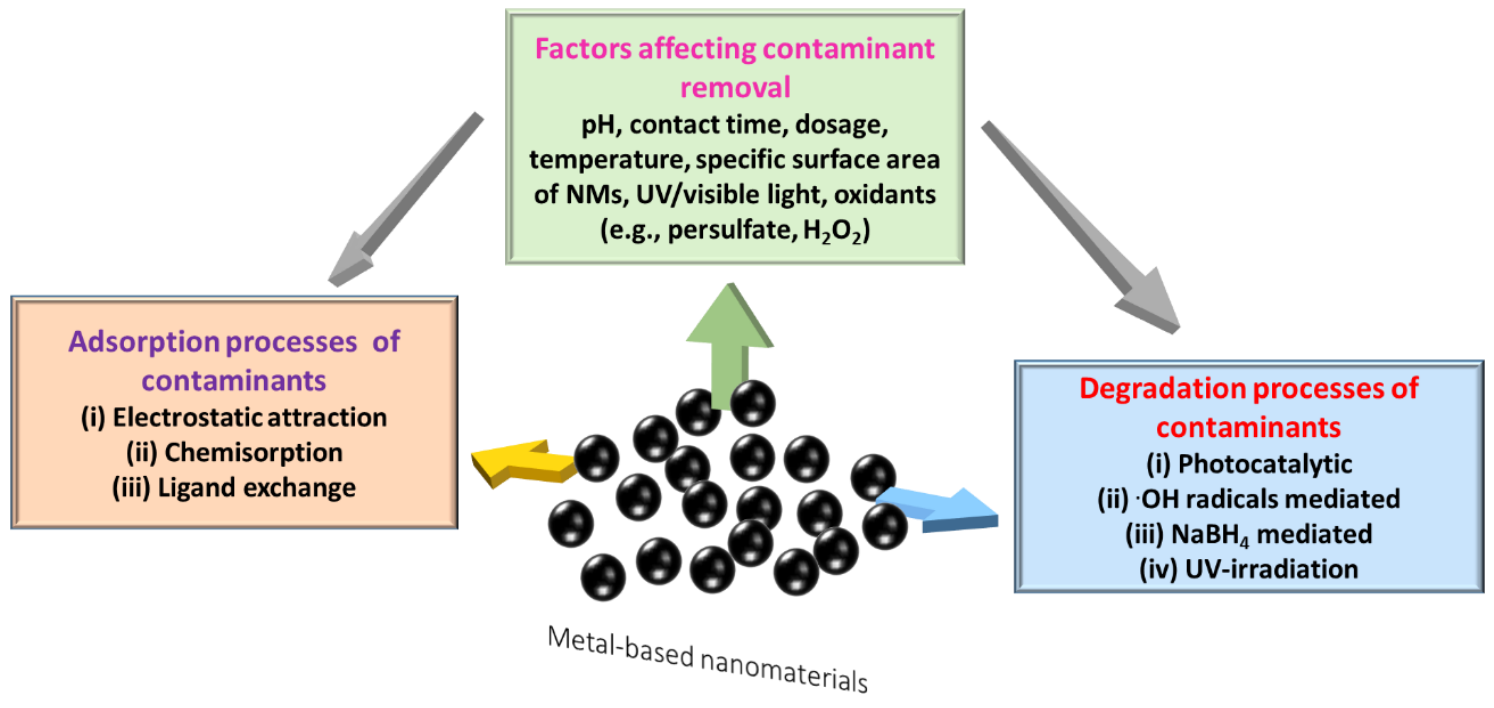

1671 Fig. 2. Factors and processes affecting the adsorption and degradation of contaminants by 1672 metal-based NMs. 


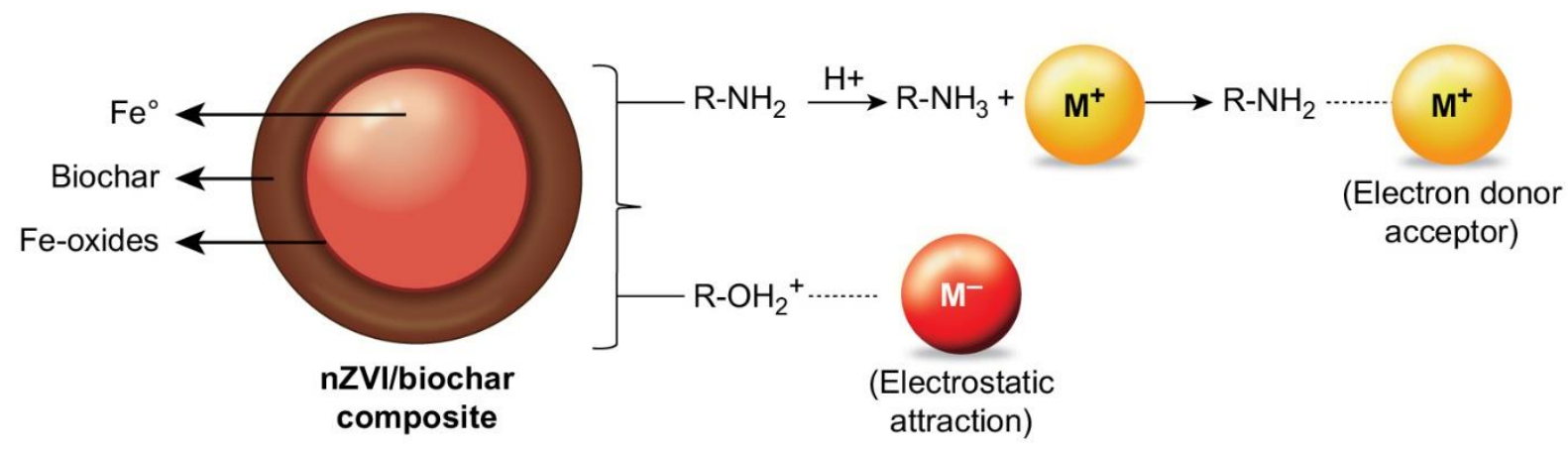

$\mathbf{M}^{+}$Represents cationic contaminant

$\mathbf{M}^{-}$Represents anionic contaminant 1675

1676 Fig. 3. Mechanisms of contaminants removal by nZVI/biochar composites (adapted from 1677 (Zhu et al., 2018)) 

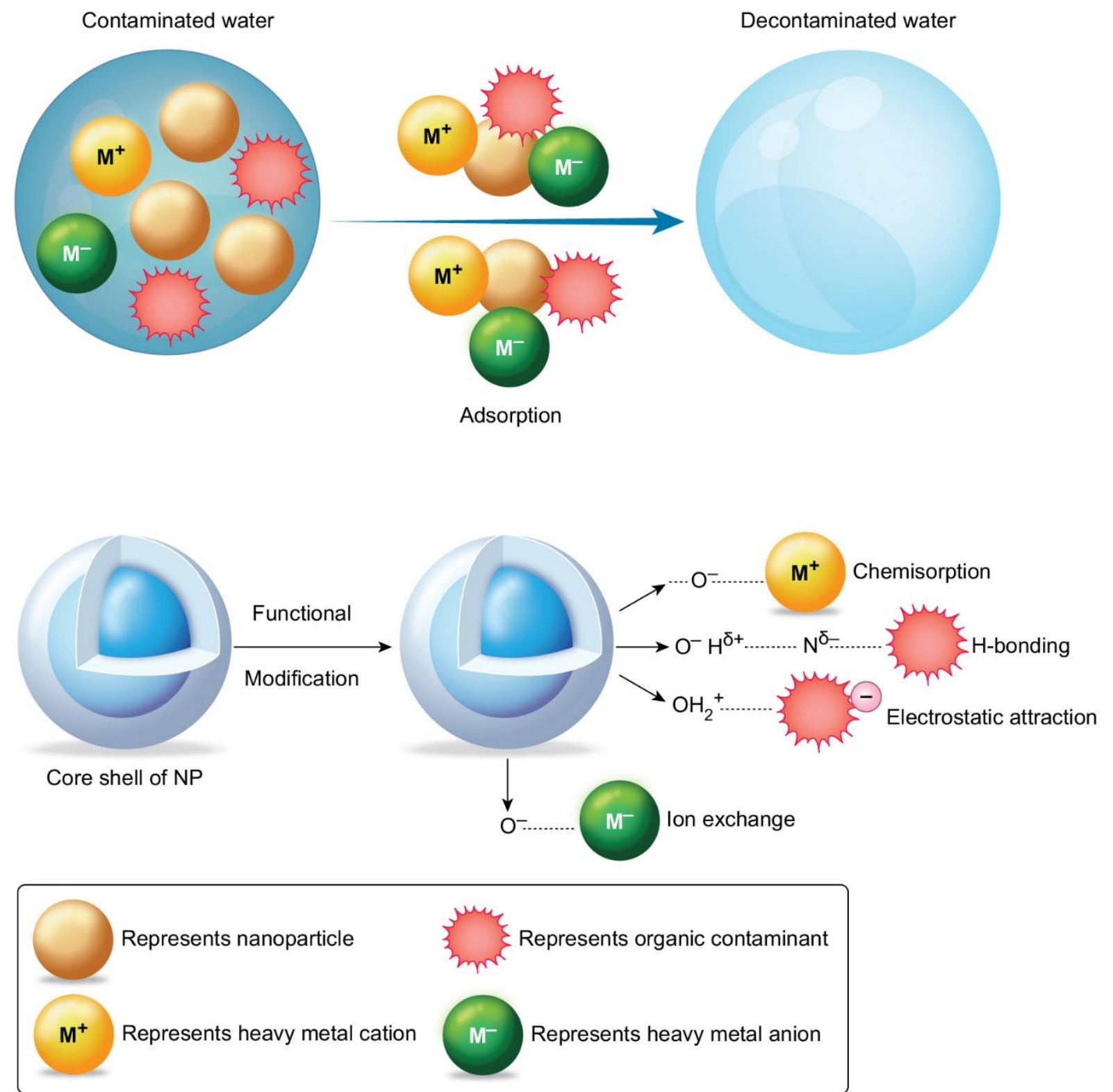

1679

1680 Fig. 4. Adsorption of contaminants onto nanoparticles, and mechanisms involved (adapted 1681 from (Mukhopadhyay et al., 2020; Uddin, 2017)). 

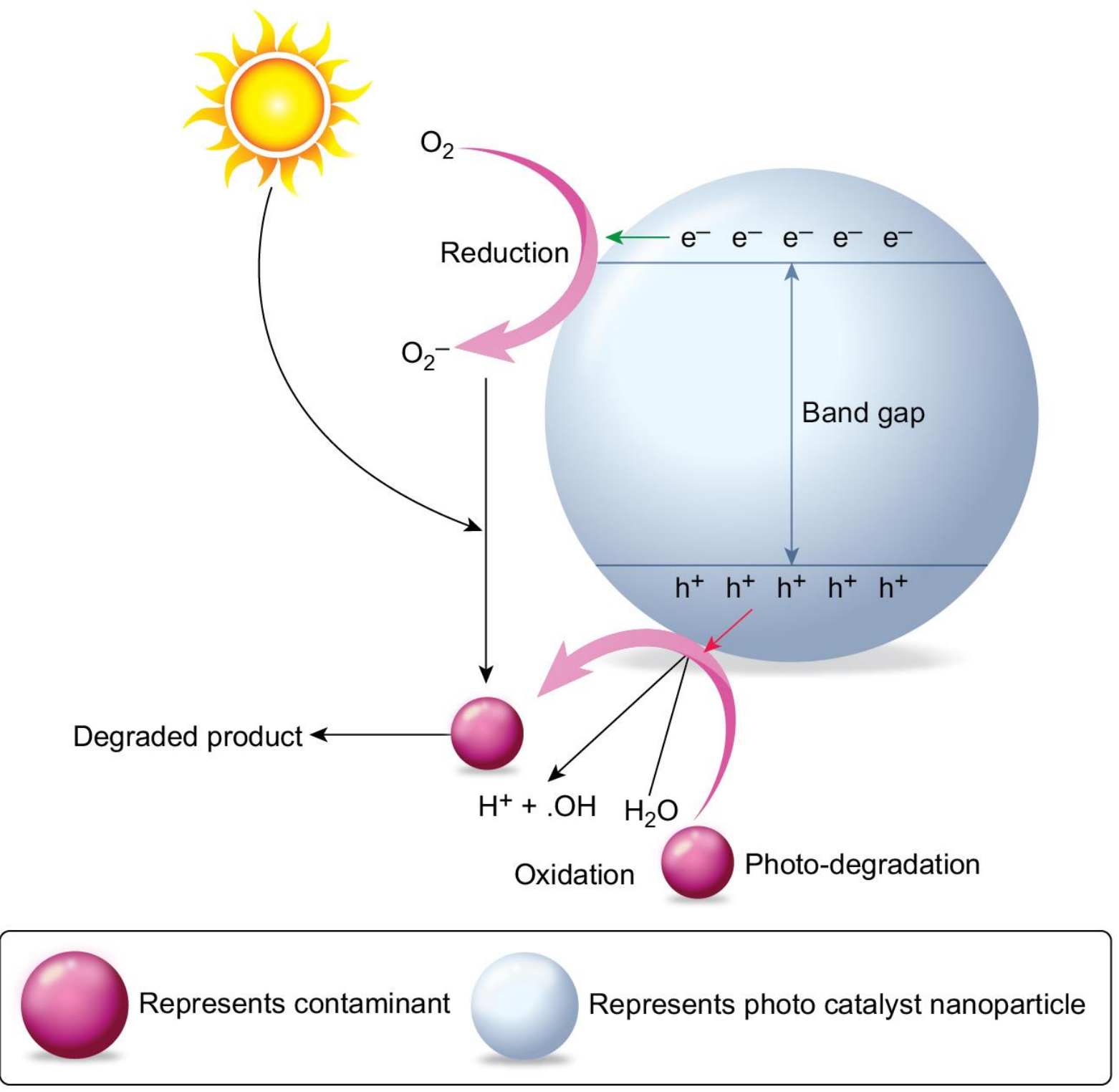

1683

1684 Fig. 5. Photodegradation of contaminants in the presence of a photocatalyst nanoparticle 1685 (adapted from (Chong et al., 2010)).

1686 
Supplementary Information for:

1688 Nanomaterials for sustainable remediation of chemical contaminants in water and soil

1689 Raj Mukhopadhyay ${ }^{\mathrm{a}}$, Binoy Sarkar, ${ }^{\mathrm{b}, *}$, Eakalak Khan ${ }^{\mathrm{c}}$, Daniel S. Alessi ${ }^{\mathrm{d}}$, Jayanta Kumar Biswas ${ }^{\mathrm{e}}, \mathrm{K}$.

1690 M. Manjaiah ${ }^{\mathrm{f}}$, Miharu Eguchi ${ }^{\mathrm{g}}$, Kevin C.W. Wu ${ }^{\mathrm{h}}$, Yusuke Yamauchi ${ }^{\mathrm{ij},}$, Yong Sik Ok ${ }^{\mathrm{k}, *}$

$1691{ }^{a}$ Division of Irrigation and Drainage Engineering, ICAR-Central Soil Salinity Research Institute,

1692 Karnal-132001, Haryana, India

$1693{ }^{b}$ Lancaster Environment Centre, Lancaster University, Lancaster, LA1 4YQ, United Kingdom

$1694{ }^{c}$ Department of Civil and Environmental Engineering and Construction, University of Nevada, Las

1695 Vegas, NV 89154, USA

$1696{ }^{d}$ University of Alberta, Earth and Atmospheric Sciences, Edmonton, AB, T6G 2E3, Canada

$1697{ }^{e}$ Department of Ecological Studies \& International Centre for Ecological Engineering, University of 1698 Kalyani, Kalyani, Nadia- 741235, West Bengal, India

$1699 \quad{ }^{f}$ ICAR-Indian Agricultural Research Institute, New Delhi - 110012, India

$1700 \quad{ }^{g}$ Electronic Functional Materials Group, National Institute for Materials Science (NIMS), 1-1

1701 Namiki, Tsukuba, Ibaraki 305-0044, Japan

$1702{ }^{h}$ Department of Chemical Engineering, National Taiwan University, Taipei 10617, Taiwan

$1703{ }^{i}$ Australian Institute for Bioengineering and Nanotechnology (AIBN) and School of Chemical

1704 Engineering, The University of Queensland, Brisbane, QLD 4072, Australia

$1705{ }^{j}$ Yamauchi Materials Space-Tectonics Project and International Center for Materials

1706 Nanoarchitechtonics (WPI-MANA), National Institute for Materials Science (NIMS), 1-1 Namiki,

1707 Tsukuba, Ibaraki 305-0044, Japan

$1708{ }^{k}$ Korea Biochar Research Center, APRU Sustainable Waste Management Program \& Division of 1709 Environmental Science and Ecological Engineering, Korea University, Seoul 02841, Republic of

$1710 \quad$ Korea

$1711{ }^{*}$ Co-corresponding authors:

1712 Dr. Binoy Sarkar, Lancaster University, e-mail: b.sarkar@lancaster.ac.uk

1713 Prof. Yong Sik Ok, Korea University, e-mail: yongsikok@korea.ac.kr 
1715 Table S1. Contaminant adsorption, degradation and removal efficiencies by Fe NPs in water systems.

\begin{tabular}{|c|c|c|c|c|c|}
\hline Iron based nanoparticles & Contaminants & $\begin{array}{l}\text { Amount removed } \\
\text { /removal efficiency }\end{array}$ & $\begin{array}{l}\text { Contact } \\
\text { time }\end{array}$ & Mechanism(s) & References \\
\hline nZVI & $\mathrm{Co}(\mathrm{II})$ & $172 \mathrm{mg} / \mathrm{g}$ & $10 \min$ & $\begin{array}{l}\text { Adsorption on negative charges } \\
\text { developed upon hydroxylation of } \\
\text { nZVI }\end{array}$ & $\begin{array}{l}\text { Üzüm et al., } \\
2008\end{array}$ \\
\hline $\begin{array}{l}\text { Forager sponge-loaded } \\
\text { superparamagnetic iron oxide } \\
\text { NPs }\end{array}$ & $\mathrm{As}(\mathrm{III})$ and $\mathrm{As}(\mathrm{V})$ & $\begin{array}{l}\mathrm{As}(\mathrm{III}): 2.1 \mathrm{mmol} / \mathrm{g} \\
\mathrm{As}(\mathrm{V}): 12.1 \mathrm{mmol} / \mathrm{g}\end{array}$ & $10 \min$ & $\begin{array}{l}\text { Adsorption via anion exchange } \\
\text { and ligand exchange }\end{array}$ & $\begin{array}{l}\text { Morillo et al., } \\
2015\end{array}$ \\
\hline $\begin{array}{l}\text { Ascorbic acid coated } \mathrm{Fe}_{3} \mathrm{O}_{4} \\
\text { NPs }\end{array}$ & $\mathrm{As}(\mathrm{III})$ and $\mathrm{As}(\mathrm{V})$ & $\begin{array}{l}\mathrm{As}(\mathrm{III}): 40.06 \mathrm{mg} / \mathrm{g} \\
\mathrm{As}(\mathrm{V}): 16.56 \mathrm{mg} / \mathrm{g}\end{array}$ & $30 \min$ & $\begin{array}{l}\text { Adsorption on high surface area } \\
\text { and separation using external } \\
\text { magnetic field }\end{array}$ & $\begin{array}{l}\text { Feng et al., } \\
2012\end{array}$ \\
\hline $\begin{array}{l}\text { Green nano-iron particles and } \\
\text { chitosan composite }\end{array}$ & $\mathrm{As}(\mathrm{III})$ and $\mathrm{As}(\mathrm{V})$ & $\begin{array}{l}\text { As(III): } 98.79 \% \\
\text { As(V): } 99.65 \%\end{array}$ & $30 \mathrm{~min}$ & Adsorption through ion exchange & $\begin{array}{l}\text { Prasad et al., } \\
2014\end{array}$ \\
\hline nZVI & $\mathrm{PO}_{4}^{3-}$ & $96-100 \%$ & $30 \min$ & $\begin{array}{l}\text { Adsorption through } \mathrm{pH} \text {-induced } \\
\text { positive charge formation }\end{array}$ & $\begin{array}{l}\text { Almeelbi \& } \\
\text { Bezbaruah, } \\
2012\end{array}$ \\
\hline nZVI & $\mathrm{Cd}(\mathrm{II})$ and $\mathrm{Ni}(\mathrm{II})$ & $\begin{array}{l}\mathrm{Cd}(\mathrm{II}): 65 \% \\
\mathrm{Ni}(\mathrm{II}): 27 \%\end{array}$ & $2 \mathrm{~h}$ & $\begin{array}{l}\text { Removal through } \mathrm{pH} \text { rises and } \\
\text { aging effect of nZVI }\end{array}$ & $\begin{array}{l}\text { Calderon \& } \\
\text { Fullana, } 2015\end{array}$ \\
\hline Sulfidized derivative of nZVI & $\mathrm{Cd}(\mathrm{II})$ & $80 \%$ & $1 \mathrm{~h}$ & $\begin{array}{l}\text { Removal by complex formation } \\
\text { between sulfidized nZVI-Cd }\end{array}$ & $\begin{array}{l}\text { Stevenson et } \\
\text { al., } 2017\end{array}$ \\
\hline nZVI & $\mathrm{Cr}(\mathrm{VI})$ & $3.33 \mathrm{mg} / \mathrm{g}$ & $24 \mathrm{~h}$ & Reduction of $\mathrm{Cr}(\mathrm{VI})$ to $\mathrm{Cr}(\mathrm{III})$ & $\begin{array}{l}\text { Vilardi et al., } \\
2018\end{array}$ \\
\hline Polyethylenimine coated-nZVI & $\mathrm{Cr}(\mathrm{VI})$ & $99.9 \%$ & $10 \min$ & $\begin{array}{l}\text { Oxidation of nZVI to } \mathrm{Fe}_{2} \mathrm{O}_{3} \text { and } \\
\mathrm{Fe}_{3} \mathrm{O}_{4}\end{array}$ & $\begin{array}{l}\text { Mdlovu et al., } \\
2020\end{array}$ \\
\hline Iron oxide NPs & $\mathrm{Cr}(\mathrm{VI})$ & $4.62 \mathrm{mg} / \mathrm{g}$ & $2 \mathrm{~h}$ & Chemisorption & $\begin{array}{l}\text { Mahanty et al., } \\
2019\end{array}$ \\
\hline Sulfidated nZVI & $\mathrm{Cr}(\mathrm{VI})$ & $100 \%$ & $3 \mathrm{~h}$ & Surface reduction and precipitation & Zou et al., 2019 \\
\hline CNTs/nZVI composites & Se and Co & $\begin{array}{l}\text { Se: } 2.52 \mathrm{mg} / \mathrm{g} \\
\text { Co: } 2.35 \mathrm{mg} / \mathrm{g}\end{array}$ & $24 \mathrm{~h}$ & Removal by chemisorption & $\begin{array}{l}\text { Vilardi et al., } \\
2018\end{array}$ \\
\hline
\end{tabular}


nZVI

nZVI

Sodium hypochlorite $(\mathrm{NaClO})$ modified nZVI

Iron oxide NPs dispersed onto zeolite by Eucalyptus leaf

extracts

Starch modified nZVI

Zero valent $(\mathrm{Fe} / \mathrm{Ni}) \mathrm{BNP}$

Potassium persulfate modified

$\mathrm{Fe}_{3} \mathrm{O}_{4}$

nZVI-B (Sodium borohydride method) and nZVI-T

(Commercially purchased)

Zeolite-supported Fe NPs

nZVI

nZVI

Clinoptilolite/nZVI composite

Fe-NPs
$\mathrm{Yb}$ and $\mathrm{La}$ (rare earth

elements)

Uranium (U(VI))

$\mathrm{PO}_{4}{ }^{3-}$

$\mathrm{NH}_{4}{ }^{+}$and $\mathrm{PO}_{4}{ }^{3-}$

$\mathrm{NO}_{3}{ }^{-}$

Profenofos

Aldrin, eldrin and lindane

DT [1,1,1-trichloro2,2-

bis(p-chlorophenyl)

ethane]

Methomyl

Alachlor

Tributyltin and trimethyltin

$\mathrm{MB}$ and $\mathrm{MO}$

MO
Yb: $410 \mathrm{mg} / \mathrm{g}$
La: $61 \mathrm{mg} / \mathrm{g}$

$99 \%$

$94.8-98.2 \%$

$\mathrm{NH}_{4}^{+}: 3.47 \mathrm{mg} / \mathrm{g}$

$\mathrm{PO}_{4}{ }^{3-}: 38.91 \mathrm{mg} / \mathrm{g}$

$91 \%$

$94.51 \%$

Aldrin: $24.7 \mathrm{mg} / \mathrm{g}$

Eldrin: $33.5 \mathrm{mg} / \mathrm{g}$

Lindane: $10.2 \mathrm{mg} / \mathrm{g}$

nZVI-B: $92 \%$

nZVI-T: $78 \%$

$100 \%$

$92-96 \%$

Tributyltin: $96 \%$

Trimethyltin: $40 \%$

MB: $96.6 \%$

MO: $90.2 \%$

$100 \%$ degradation
30 min Surface mediated precipitation

$<10$ min Removal via reduction, sorption and precipitation

$12 \mathrm{~min}$ Rapid oxidation due to presence of

$\mathrm{NaClO}$ as oxidant

$15 \mathrm{~min}$ Chemisorption

Force electromagnetism

Degradation by deprotonation at

high $\mathrm{pH}$

10 min Removal by chemisorption

$24 \mathrm{~h}$ Degradation due to highly reactive functional surface sites

Degradation via photocatalytic oxidation

$72 \mathrm{~h}$

Reductive degradation by nZVI

7 days

High pH (8.0) followed by acidification with citric acid at $\mathrm{pH}$ 3.0

MB: 15 Adsorption under wider dispersion

$\min$

MO: 30

$\min$

$6 \mathrm{~h}$

of Fe nanoparticle chains in

clinoptilolite matrix

Strong electrostatic attraction
Crane \&

Sapsford, 2018

Hua et al., 2018

Luo et al., 2020

Xu et al., 2020

Mofradnia et

al., 2019

Mansouriieh et

al., 2019

Lan et al., 2014

El-Temsah et

al., 2016

Tomašević et

al., 2010

Bezbaruah et

al., 2009

Peeters et al.,

2015

rat et al.,

2015

between anionic MO and Fe-NPs

below point of zero charge of $\mathrm{Fe}$ -

NPs
Xingu-

Contreras et al. 2020 
nZVI

$\mathrm{nZVI} / \mathrm{H}_{2} \mathrm{O}_{2}$ (Fenton like system)

Granular reinforced ZVI

activated by persulfate

Biochar supported nZVI

Wheat straw supported nZVI

Polyethylenimine

(PEI) surface-modified zero-

valent iron NPs (PEIenZVI)

Sulfide-modified nZVI

Sulfide-modified

$n Z V I / g r a p h e n e$ aerogel

composite

Heat treated biochar

impregnated nZVI

\begin{tabular}{|c|c|c|c|c|}
\hline Reactive yellow & $59.9 \%$ & $5 \mathrm{~min}$ & $\begin{array}{l}\text { Removal via corrosion of } \mathrm{nZVI} \\
\text { and } \mathrm{Fe}(\mathrm{II}) \text { consumption }\end{array}$ & $\begin{array}{l}\text { Mao et al., } \\
2015\end{array}$ \\
\hline MB & $94.5 \%$ & $1 \mathrm{~h}$ & OH radical oxidation & $\begin{array}{l}\text { Yang et al., } \\
2019\end{array}$ \\
\hline Acid orange 7 & $90.78 \%$ & $2 \mathrm{~h}$ & Diffusion mediated reduction & Du et al., 2020 \\
\hline Ciprofloxacin & $70 \%$ & $1 \mathrm{~h}$ & $\mathrm{OH}$ radical oxidation & $\begin{array}{l}\text { Mao et al., } \\
2019\end{array}$ \\
\hline $\mathrm{Cu}(\mathrm{II})$, chlorotetracycline & $\begin{array}{l}\mathrm{Cu}(\mathrm{II}): 376.4 \mathrm{mg} / \mathrm{g} \\
\text { Chlorotetracycline: } \\
1280.8 \mathrm{mg} / \mathrm{g}\end{array}$ & $2 \mathrm{~h}$ & Chemisorption and redox reaction & $\begin{array}{l}\text { Shao et al., } \\
2020\end{array}$ \\
\hline $\begin{array}{l}\text { Trichloroethylene, } \\
\text { perchloroethylene, and 1,2- } \\
\text { dichloroethene }\end{array}$ & $99 \%$ & $2 \mathrm{~h}$ & $\begin{array}{l}\text { Removal through high surface area } \\
\left(53.4 \mathrm{~m}^{2} / \mathrm{g}\right) \text { particles }\end{array}$ & Lin et al., 2018 \\
\hline Trichloroethylene & $66 \%$ & $1 \mathrm{~h}$ & Strong corrosion of $\mathrm{Fe}^{\circ}$ & $\begin{array}{l}\text { Wang et al., } \\
2020\end{array}$ \\
\hline Trichloroethylene & $100 \%$ & $50 \mathrm{~min}$ & $\begin{array}{l}\text { Electron transfer from Fe core to } \\
\text { trichloroethylene }\end{array}$ & Bin et al., 2020 \\
\hline Trichloroethylene & $88 \%$ & $20 \mathrm{~min}$ & Chemisorption & $\begin{array}{l}\text { Mortazavian et } \\
\text { al., } 2019\end{array}$ \\
\hline
\end{tabular}

'-' indicates unavailability of information on contact time. 
Table S2. Cu NPs for contaminant adsorption/removal/degradation in water.

\begin{tabular}{|c|c|c|c|c|c|}
\hline $\begin{array}{l}\text { Copper based } \\
\text { nanoparticles }\end{array}$ & Contaminants & $\begin{array}{l}\text { Amount removed } \\
\text { /removal } \\
\text { efficiency }\end{array}$ & $\begin{array}{l}\text { Contact } \\
\text { time }\end{array}$ & Mechanism(s) & References \\
\hline $\begin{array}{l}\text { Chitosan encapsulated } \\
\mathrm{CuO}\end{array}$ & As(V) & $28.1 \mathrm{mg} / \mathrm{g}$ & $3.5 \mathrm{~h}$ & Adsorption by electrostatic attraction & $\begin{array}{l}\text { Elwakeel \& } \\
\text { Guibal, } 2015\end{array}$ \\
\hline $\mathrm{CuO}-\mathrm{Fe}_{3} \mathrm{O}_{4}$ & $\operatorname{As}(\mathrm{V})$ & $118.11 \mathrm{mg} / \mathrm{g}$ & $1 \mathrm{~h}$ & $\begin{array}{l}\text { Removal through protonation and } \\
\text { improved electrostatic gravity under } \\
\text { acidic conditions }\end{array}$ & Sun et al., 2017 \\
\hline $\mathrm{CuFe}_{2} \mathrm{O}_{4}$ & As & $45.7 \mathrm{mg} / \mathrm{g}$ & $5 \mathrm{~h}$ & Bonding with reactive surface sites & $\begin{array}{l}\text { Masunga et al., } \\
2019\end{array}$ \\
\hline $\begin{array}{l}\mathrm{Cu} \text { NPs intercalated } \\
\text { into CNTs }\end{array}$ & $\mathrm{As}(\mathrm{III})$ & $>90 \%$ & $66.7 \mathrm{~h}$ & Adsorptive filtration and partial oxidation & Luan et al., 2019 \\
\hline $\mathrm{CuO}$ NPs & $\mathrm{Cr}(\mathrm{VI})$ & $18.51 \mathrm{mg} / \mathrm{g}$ & $3 \mathrm{~h}$ & Removal by chemisorption & Gupta et al., 2016 \\
\hline $\begin{array}{l}\text { Alginate-coated } \\
\text { chitosan } / \mathrm{CuO}\end{array}$ & $\mathrm{Ni}(\mathrm{II})$ & $94.48 \%$ removal & $30 \min$ & $\begin{array}{l}\text { Removal through formation of less } \\
\text { soluble hydrolyzed products such as } \\
\mathrm{NiOH} \text { and } \mathrm{Ni}(\mathrm{OH})_{2} \text { at } \mathrm{pH} 3.0\end{array}$ & $\begin{array}{l}\text { Esmaeili \& } \\
\text { Khoshnevisan, } \\
2016\end{array}$ \\
\hline $\begin{array}{l}\text { Nano structured } \mathrm{CuO} \\
\text { granules }\end{array}$ & $\mathrm{Pb}(\mathrm{II})$ & $55.24 \mathrm{mg} / \mathrm{g}$ & $5 \mathrm{~h}$ & $\begin{array}{l}\text { Adsorption via strong electrostatic } \\
\text { attraction under alkaline conditions }\end{array}$ & $\begin{array}{l}\text { Ahmadi et al., } \\
2012\end{array}$ \\
\hline $\begin{array}{l}\text { Amine-functionalized } \\
\text { copper ferrite chelated } \\
\text { with La(III) }\end{array}$ & $\mathrm{PO}_{4}^{3-}$ & $12.6 \mathrm{mg} / \mathrm{g}$ & $40 \min$ & Chemisorption & Gu et al., 2018 \\
\hline $\begin{array}{l}\text { Cu NPs coated biochar } \\
\text { (bamboo shoot shell) }\end{array}$ & $\operatorname{Re}(\mathrm{VII})$ & $20.91 \mathrm{mg} / \mathrm{g}$ & $5 \mathrm{~h}$ & Complexation & Hu et al., 2018 \\
\hline $\begin{array}{l}\text { CuI-CuO NPs loaded } \\
\text { activated carbon }\end{array}$ & Malachite green & $136.67 \mathrm{mg} / \mathrm{g}$ & $\geq 25 \min$ & $\begin{array}{l}\text { Adsorption via electrostatic attraction at } \\
\text { low } \mathrm{pH}\end{array}$ & $\begin{array}{l}\text { Nekouei et al., } \\
2015\end{array}$ \\
\hline $\begin{array}{l}3.025 \% \mathrm{Cu} \text {-embedded } \\
\text { chitosan }\end{array}$ & Rhodamine B & $99 \%$ degradation & $1 \mathrm{~h}$ & Degradation through active $\cdot \mathrm{OH}$ radicals & $\begin{array}{l}\text { Senthil Kumar et } \\
\text { al., } 2015\end{array}$ \\
\hline $\begin{array}{l}\mathrm{CuO} \text { nano-needles on } \\
\mathrm{GO} \text { sheets }\end{array}$ & $\begin{array}{l}\text { Coomassie brilliant blue } \\
\text { (CBB), MB, Congo red (CR) } \\
\text { and amido black 10B (AB) }\end{array}$ & $>98 \%$ removal & $13.33 \mathrm{~h}$ & $\begin{array}{l}\text { Adsorption via strong electrostatic } \\
\text { attraction and high surface area of } \mathrm{CuO} \\
\text { nano-needles on } \mathrm{GO} \text { sheets }\end{array}$ & $\begin{array}{l}\text { Rajesh et al., } \\
2016\end{array}$ \\
\hline $30 \% \mathrm{Cu}_{2} \mathrm{O} / \mathrm{TiO}_{2}$ & Acid red B & $\begin{array}{l}>70 \% \\
\text { decolorization }\end{array}$ & $1 \mathrm{~h}$ & $\begin{array}{l}\text { Adsorptive decolorization via } \\
\text { electrostatic attraction and large surface } \\
\text { area of } \mathrm{Cu}_{2} \mathrm{O} / \mathrm{TiO}_{2}\end{array}$ & Fei et al., 2015 \\
\hline
\end{tabular}




\begin{tabular}{|c|c|c|c|c|c|}
\hline Bio-engineered $\mathrm{Cu}$ NPs & Alizarin Yellow R & $89.71 \%$ & $36 \mathrm{~h}$ & $\begin{array}{l}\text { Combination of van der Waals forces, } \\
\text { electrostatic attraction and H-bonding }\end{array}$ & $\begin{array}{l}\text { Usman et al., } \\
2019\end{array}$ \\
\hline $\mathrm{CuO} /$ nanoTiO $_{2}$ & MB & $99 \%$ degradation & $5 \mathrm{~h}$ & $\begin{array}{l}\text { Degradation via electron scavenging } \\
\text { effect of } \mathrm{Cu}^{2+} \text { in seawater }\end{array}$ & $\begin{array}{l}\text { Simamora et al., } \\
2012\end{array}$ \\
\hline $\begin{array}{l}\text { Cu-oxide NPs annealed } \\
\text { at } 600^{\circ} \mathrm{C}\end{array}$ & MB & $91 \%$ degradation & $2.5 \mathrm{~h}$ & $\begin{array}{l}\text { Generation of more electro-hole pairs and } \\
\text { reduction in the electron-hole } \\
\text { recombination rate }\end{array}$ & $\begin{array}{l}\text { Nwanya et al., } \\
2019\end{array}$ \\
\hline $\mathrm{Cu}_{2} \mathrm{O}$-zeolite & 1,2-Dichloroethane & $83.8 \%$ removal & $2 \mathrm{~h}$ & $\begin{array}{l}\text { Removal under UV irradiation at low } \\
\text { relative humidity }(15 \%)\end{array}$ & Lin et al., 2014 \\
\hline Zero valent $\mathrm{Cu}$ & Dichloromethane & $90 \%$ degradation & $1 \mathrm{~h}$ & $\begin{array}{l}\text { Degradation through hydrodechlorination } \\
\text { with a high dose of zero valent } \mathrm{Cu}(2.5 \\
\mathrm{g} / \mathrm{L})\end{array}$ & $\begin{array}{l}\text { Huang et al., } \\
2012\end{array}$ \\
\hline $\begin{array}{l}\text { Zero valent } \mathrm{Cu} \text { and } \\
\text { reductant } \mathrm{NaBH}_{4}\end{array}$ & Mono chloroaromatic & $90 \%$ dechlorinated & $12 \mathrm{~h}$ & $\begin{array}{l}\text { Dechlorination through breaking of } \mathrm{Ar}-\mathrm{Cl} \\
\text { bond by e- produced by } \mathrm{NaBH}_{4} \text { and } \\
\text { formation of Ar-H bond on zero valent } \\
\mathrm{Cu}\left(\mathrm{Cu}^{0}\right) \text {. }\end{array}$ & Raut et al., 2016 \\
\hline Nano $\mathrm{CuO}$ & Nitrobenzene & $100 \%$ degradation & $25 \mathrm{~min}$ & Degradation by $\bullet \mathrm{OH}$ radicals & $\begin{array}{l}\text { ElShafei et al., } \\
2014\end{array}$ \\
\hline $\mathrm{Cu}$-doped $\mathrm{TiO}_{2}$ & Phenol & $52 \%$ degradation & $3 \mathrm{~h}$ & $\begin{array}{l}\text { Degradation through electron }\left(\mathrm{e}^{-}\right) \\
\text {scavenging effect of } \mathrm{Cu}^{2+} \text { and prevention } \\
\text { of recombination of electron hole pairs }\end{array}$ & $\begin{array}{l}\text { Sohrabi \& } \\
\text { Akhlaghian, } 2016\end{array}$ \\
\hline $\begin{array}{l}\text { Chitosan embedded } \mathrm{Cu} \\
\text { NPs }\end{array}$ & 4-nitroaniline & $\begin{array}{l}\text { Rate of reduction: } \\
7.51^{\times} 10^{-3} / \mathrm{s}\end{array}$ & $<4.5 \mathrm{~min}$ & $\mathrm{Cu}$ NP-assisted reduction by $\mathrm{NaBH}_{4}$ & $\begin{array}{l}\text { Bakhsh et al., } \\
2019\end{array}$ \\
\hline $\begin{array}{l}\text { Graphene-wrapped } \\
\text { zero-valent } \mathrm{Cu} \text { NPs }\end{array}$ & Metronidazole & $92 \%$ & $2 \mathrm{~h}$ & OH radical & Xu et al., 2019 \\
\hline $\mathrm{Cu}$ NPs & Ibuprofen & $36.0 \mathrm{mg} / \mathrm{g}$ & $1 \mathrm{~h}$ & Chemisorption & $\begin{array}{l}\text { Husein et al., } \\
2019\end{array}$ \\
\hline $\begin{array}{l}\text { Bentonite supported } \\
\text { green nZVI-Cu } \\
\text { nanocomposite }\end{array}$ & Tetracycline & $95 \%$ & $1.5 \mathrm{~h}$ & $\begin{array}{l}\text { OH radical production due to galvanic } \\
\text { corrosion of nZVI-Cu }\end{array}$ & Gopal et al., 2020 \\
\hline
\end{tabular}


Table S3. Adsorption of different contaminants onto various carbon nanotubes in water.

\begin{tabular}{|c|c|c|c|c|c|c|}
\hline $\begin{array}{l}\text { Types of } \\
\text { CNTs }\end{array}$ & Modification & Contaminants & $\begin{array}{l}\text { Amount adsorbed } \\
\text { /removal efficiency }\end{array}$ & $\begin{array}{l}\text { Contact } \\
\text { time }\end{array}$ & Mechanism(s) & References \\
\hline MWCNTs & $\mathrm{TiO}_{2 \text {-grafted }}$ & $\mathrm{Pb}(\mathrm{II})$ & $137 \mathrm{mg} / \mathrm{g}$ & $1 \mathrm{~h}$ & Electrostatic attraction & Zhao et al., 2010 \\
\hline MWCNTs & Nano iron oxide coated & $\mathrm{Cr}(\mathrm{III})$ & $>90 \%$ & $2 \mathrm{~h}$ & $\begin{array}{l}\mathrm{Cr} \text { (III) removal related to } \\
\text { flow rate (inverse relation) }\end{array}$ & Gupta et al., 2011 \\
\hline MWCNTs & Iron oxide-coated & $\mathrm{As}(\mathrm{V})$ and $\mathrm{As}(\mathrm{III})$ & $\begin{array}{l}\text { As(V): } 0.19 \mathrm{mg} / \mathrm{g} \\
\text { As(III): } 1.72 \mathrm{mg} / \mathrm{g}\end{array}$ & $30 \mathrm{~min}$ & $\begin{array}{l}\text { Simple electrostatic } \\
\text { Attraction }\end{array}$ & $\begin{array}{l}\text { Addo Ntim \& } \\
\text { Mitra, } 2011\end{array}$ \\
\hline MWCNTs & $\mathrm{Al}_{2} \mathrm{O}_{3}$ & $\mathrm{Cd}(\mathrm{II})$ & $27.2 \mathrm{mg} / \mathrm{g}$ & $4 \mathrm{~h}$ & Sorption & Liang et al., 2015 \\
\hline MWCNTs & Oxidized & $\mathrm{Cd}(\mathrm{II})$ & $22.4 \mathrm{mg} / \mathrm{g}$ & $30 \mathrm{~min}$ & Precipitation & $\begin{array}{l}\text { Vuković et al., } \\
2010\end{array}$ \\
\hline MWCNTs & Iodide & $\operatorname{Hg}(\mathrm{II})$ & $123.5 \mathrm{mg} / \mathrm{g}$ & $2 \mathrm{~h}$ & Chemisorption & Gupta et al., 2014 \\
\hline SWCNTs & Thiol derived & $\mathrm{Hg}(\mathrm{II})$ & $131.0 \mathrm{mg} / \mathrm{g}$ & $1 \mathrm{~h}$ & Chemisorption & $\begin{array}{l}\text { Bandaru et al., } \\
2013\end{array}$ \\
\hline MWCNTs & - & $\mathrm{Cr}(\mathrm{III})$ & $2.07 \mathrm{mmol} / \mathrm{g}$ & $30 \mathrm{~min}$ & Electrostatic attraction & Manilo et al., 2017 \\
\hline $\begin{array}{l}\text { Magnetic } \\
\text { CNTs }\end{array}$ & N-doped & $\mathrm{Cr}(\mathrm{VI})$ & $970.87 \mathrm{mg} / \mathrm{g}$ & $10 \mathrm{~min}$ & $\begin{array}{l}\text { Acid medium and } \\
\text { reduction reaction between } \\
\mathrm{Fe}^{0} \mathrm{NPs} \text { and } \mathrm{Cr}(\mathrm{VI})\end{array}$ & Huang et al., 2019 \\
\hline MWCNTs & $\mathrm{Fe}_{3} \mathrm{O}_{4}$ & As(V) & $39.1 \mathrm{mg} / \mathrm{g}$ & $1 \mathrm{~h}$ & Inner sphere complex & $\begin{array}{l}\text { Mishra \& } \\
\text { Ramaprabhu, } 2010\end{array}$ \\
\hline $\begin{array}{l}\text { Purified } \\
\text { SWCNTs }\end{array}$ & - & $\mathrm{Zn}(\mathrm{II})$ & $41.8 \mathrm{mg} / \mathrm{g}$ & $1 \mathrm{~h}$ & - & Lu et al., 2006 \\
\hline MWCNTs & $\begin{array}{l}\text { 2-(5-Bromo-2-pyridylazo)-5- } \\
\text { (diethylamino)phenol }\end{array}$ & $\mathrm{U}(\mathrm{VI})$ & $83.4 \mathrm{mg} / \mathrm{g}$ & $20 \mathrm{~min}$ & $\begin{array}{l}\text { Trinuclear, }\left(\mathrm{UO}_{2}\right)_{3}(\mathrm{OH})^{5+} \\
\text { formation }\end{array}$ & $\begin{array}{l}\text { Khamirchi et al., } \\
2018\end{array}$ \\
\hline CNTs & Oxidized & $\operatorname{Co}(\mathrm{II})$ & $69.6 \mathrm{mg} / \mathrm{g}$ & $20 \mathrm{~min}$ & Chemical interaction & $\begin{array}{l}\text { Tofighy \& } \\
\text { Mohammadi, } 2011\end{array}$ \\
\hline MWCNTs & Amidoamine & $\mathrm{Hg}(\mathrm{II})$ & $45.05 \mathrm{mg} / \mathrm{g}$ & $3 \mathrm{~h}$ & Chemisorption & $\begin{array}{l}\text { Singha Deb et al., } \\
2017\end{array}$ \\
\hline MWCNTs & $\begin{array}{l}\text { Polypyrrole-coated and } \\
\text { oxidized }\end{array}$ & $\mathrm{Pb}(\mathrm{II})$ and $\mathrm{Cu}(\mathrm{II})$ & $\begin{array}{l}\mathrm{Pb}(\mathrm{II}): 26.3 \mathrm{mg} / \mathrm{g} \\
\mathrm{Cu}(\mathrm{II}): 24.4 \mathrm{mg} / \mathrm{g}\end{array}$ & $1 \mathrm{~h}$ & $\begin{array}{l}\text { Deprotonation of } \mathrm{NH}_{2} \text { and } \\
\text { nitrogen }\end{array}$ & Nyairo et al., 2018 \\
\hline MWCNTs & Chitin/magnetite & $\mathrm{Cr}(\mathrm{VI})$ & $11.30 \mathrm{mg} / \mathrm{g}$ & $45 \min$ & $\begin{array}{l}\text { Strong interaction with } \\
\text { reactive functional groups }\end{array}$ & Salam, 2017 \\
\hline
\end{tabular}


MWCNTs $\quad \mathrm{Al}_{2} \mathrm{O}_{3}$

$\begin{array}{ll}\text { CNTs } & \text { Chitosan sponge } \\ \text { CNTs } & \text { Carbon graphite } \\ \text { MWCNTs } & \text { Oxidation } \\ \text { MWCNTs } & \text { Oxidation }\end{array}$

MWCNTs Graphene oxide

MWCNTs

SWCNTs

CNTs

Chitosan hydrogel scaffold

MWCNTs COOH-carboxylate

$\mathrm{COOH}$-cysteamine

\section{CNTs \\ Trimesoyl chloride and m- phenylenediamine grafting}

CNTs

CNTs

Magnetic

CNTs Fe/Ni NPs supported

\section{Chitosan hydrogel scaffold}

Polyethyleneimine
Cd(II)

$\mathrm{F}^{-}$

$\mathrm{Cu}(\mathrm{II})$

Diuron

Methyl orange

(MO)

Methylene blue

(MB)

Isoproturon

Atrazine

Food red 17 and

Food blue 1

Amido black 10B

$27.21 \mathrm{mg} / \mathrm{g}$

$975.4 \mathrm{mg} / \mathrm{g}$

$25 \%$

$29.82 \mathrm{mg} / \mathrm{g}$

$306 \mathrm{mg} / \mathrm{g}$

$87.9 \mathrm{mg} / \mathrm{g}$

$8.1 \mathrm{mg} / \mathrm{g}$

$4.97 \mathrm{mg} / \mathrm{g}$

Food red 17: 1480

$\mathrm{mg} / \mathrm{g}$; Food blue 1:

$1508 \mathrm{mg} / \mathrm{g}$

COOH-carboxylate: 90 $\mathrm{mg} / \mathrm{g}$

COOH-cysteamine: 131 $\mathrm{mg} / \mathrm{g}$

Phenol

2,6

dichlorophenol

Phenol

Alizarin Red S
$261.6 \mathrm{mg} / \mathrm{g}$

$82.6 \%$

(dechlorination)

$404.2 \mathrm{mg} / \mathrm{g}$

$196.08 \mathrm{mg} / \mathrm{g}$
$1 \mathrm{~h}$

$20 \min$

$-$

$1 \mathrm{~h}$

$3.5 \mathrm{~h}$

$2 \mathrm{~h}$

$50 \mathrm{~min}$

$18 \min$

$50 \mathrm{~min}$

$50 \min$

$20 \min$

$40 \min$
Electrostatic attraction

Functional groups of chitosan and CNTs

Oxidation effect

Electrostatic attraction

Electrostatic interaction

Electrostatic interaction

Strong attraction between surface reactive sites and contaminant

Chemisorption

Strong interaction with

surface functionalized

groups

Chemisorption and

protonation due to $\mathrm{pH}$ of

the medium

Electrostatic attraction

Bonding with reactive sites of $\mathrm{Fe} / \mathrm{Ni} \mathrm{NPs}$

Chemisorption

Interaction with active

sites and multiple

interactions
Verma \&

Balomajumder,

2020

Affonso et al.,

2020

Zghal et al., 2020

Deng et al., 2012

Mahmoodian et

al., 2015

Ai \& Jiang, 2012

Sotelo et al., 2012

Jung et al., 2015

Gonçalves et al.,

2020

Sadegh et al., 2016

Saleh et al., 2019

Liu et al., 2020

Alves et al., 2019

Zhang et al., 2019

'-'indicates unavailability of information on contact time. 
Table S4. Contaminant adsorption capacities of graphene oxide (GO) and GO composites in water.

\begin{tabular}{|c|c|c|c|c|c|}
\hline Heavy metals & Adsorbents & $\begin{array}{l}\text { Amount adsorbed } \\
\text { /removal efficiency }\end{array}$ & Contact time & Mechanism(s) & References \\
\hline $\mathrm{Cu}(\mathrm{II})$ & $\mathrm{GO}$ & $46.6 \mathrm{mg} / \mathrm{g}$ & - & $\begin{array}{l}\text { Electrostatic attraction and } \\
\text { coordination between } \mathrm{Cu}(\mathrm{II}) \\
\text { and carboxyl groups }\end{array}$ & $\begin{array}{l}\text { Yang et al., } \\
2010\end{array}$ \\
\hline $\mathrm{Cd}(\mathrm{II}), \mathrm{Ni}(\mathrm{II})$ & GO & $\begin{array}{l}\mathrm{Cd}(\mathrm{II}): 83.3 \mathrm{mg} / \mathrm{g} \\
\mathrm{Ni}(\mathrm{II}): 62.3 \mathrm{mg} / \mathrm{g}\end{array}$ & $10 \min$ & Lewis acid base interaction & $\begin{array}{l}\text { Tan et al., } \\
2015\end{array}$ \\
\hline $\mathrm{Pb}(\mathrm{II})$ & Few layered GO & $842 \mathrm{mg} / \mathrm{g}$ & $24 \mathrm{~h}$ & Surface complexation & $\begin{array}{l}\text { Zhao et al., } \\
2011\end{array}$ \\
\hline $\mathrm{Sb}(\mathrm{III})$ & Reduced GO (rGO) & $8.1 \mathrm{mg} / \mathrm{g}$ & $4 \mathrm{~h}$ & van der Waals force & $\begin{array}{l}\text { Leng et al., } \\
2012\end{array}$ \\
\hline $\mathrm{Zn}(\mathrm{II})$ & GO & $245.7 \mathrm{mg} / \mathrm{g}$ & $20 \min$ & $\begin{array}{l}\text { Ion exchange and electrostatic } \\
\text { attraction }\end{array}$ & $\begin{array}{l}\text { Wang et al., } \\
2013\end{array}$ \\
\hline $\mathrm{Eu}(\mathrm{III})$ & GO nanosheets & $175.4 \mathrm{mg} / \mathrm{g}$ & $48 \mathrm{~h}$ & $\begin{array}{l}\text { Mononuclear and binuclear } \\
\text { complexes }\end{array}$ & $\begin{array}{l}\text { Sun et al., } \\
2012\end{array}$ \\
\hline $\mathrm{Hg}(\mathrm{II}), \mathrm{Cu}(\mathrm{II}), \mathrm{Pb}(\mathrm{II})$ & EDTA*-GO & $\begin{array}{l}\mathrm{Hg}(\mathrm{II}): 268.4 \mathrm{mg} / \mathrm{g} \\
\mathrm{Cu}(\mathrm{II}): 301.2 \mathrm{mg} / \mathrm{g} \\
\mathrm{Pb}(\mathrm{II}): 508.4 \mathrm{mg} / \mathrm{g}\end{array}$ & $\begin{array}{l}\mathrm{Hg}(\mathrm{II}): 50 \\
\min \\
\mathrm{Cu}(\mathrm{II}): 90 \mathrm{~min} \\
\mathrm{~Pb}(\mathrm{II}): 40 \mathrm{~min}\end{array}$ & Electrostatic attraction & $\begin{array}{l}\text { Cui et al., } \\
2015\end{array}$ \\
\hline $\mathrm{Co}(\mathrm{II})$ & $\mathrm{GO}-\mathrm{NH}_{2}$ & $116.4 \mathrm{mg} / \mathrm{g}$ & $5 \mathrm{~min}$ & $\begin{array}{l}\text { Complexation with carboxyl } \\
\text { and amino groups on GO } \\
\text { surfaces }\end{array}$ & $\begin{array}{l}\text { Fang et al., } \\
2014\end{array}$ \\
\hline $\mathrm{U}(\mathrm{VI})$ & $\mathrm{rGO} / \mathrm{CoFe}_{2} \mathrm{O}_{4} /$ polyaniline & $2430 \mathrm{mg} / \mathrm{g}$ & $4 \mathrm{~h}$ & Strong electrostatic attraction & $\begin{array}{l}\text { Dat et al., } \\
2018\end{array}$ \\
\hline $\operatorname{As}(V)$ & $\begin{array}{l}\mathrm{GO} / \mathrm{CuFe}_{2} \mathrm{O}_{4} \text { held onto } \mathrm{Fe}-\mathrm{Ni} \\
\text { foam }\end{array}$ & $125 \mathrm{mg} / \mathrm{g}$ & $30 \mathrm{~min}$ & Ligand exchange & $\begin{array}{l}\text { Wu et al., } \\
2018\end{array}$ \\
\hline $\operatorname{As}(\mathrm{V})$ & $\mathrm{GO} / \mathrm{MnFe}_{2} \mathrm{O}_{4}$ & $240 \mathrm{mg} / \mathrm{g}$ & $20 \mathrm{~min}$ & $\begin{array}{l}\text { Bonding with active sorption } \\
\text { sites }\end{array}$ & $\begin{array}{l}\text { Huong et al., } \\
2016\end{array}$ \\
\hline $\mathrm{Pb}(\mathrm{II}), \mathrm{Cr}(\mathrm{III}), \mathrm{Cu}(\mathrm{II})$ & Magnetic GO & $\begin{array}{l}\mathrm{Pb}(\mathrm{II}): 200 \mathrm{mg} / \mathrm{g} \\
\mathrm{Cr}(\mathrm{III}): 24.3 \mathrm{mg} / \mathrm{g} \\
\mathrm{Cu}(\mathrm{II}): 62.8 \mathrm{mg} / \mathrm{g}\end{array}$ & $\begin{array}{l}\mathrm{Pb}(\mathrm{II}): 25 \min \\
\mathrm{Cr}(\mathrm{III}): 35 \\
\min \mathrm{Cu}(\mathrm{II}): 25 \\
\min \end{array}$ & $\begin{array}{l}\text { Electrostatic attraction and } \\
\text { precipitation }\end{array}$ & $\begin{array}{l}\text { Ain et al., } \\
2020\end{array}$ \\
\hline
\end{tabular}




\begin{tabular}{|c|c|c|c|c|c|}
\hline $\mathrm{Hg}(\mathrm{II})$ & $\begin{array}{l}\text { Polyamine modified rGO in } \\
\text { hydrothermal method }\end{array}$ & $63.8 \mathrm{mg} / \mathrm{g}$ & $10 \mathrm{~min}$ & Chemisorption & $\begin{array}{l}\text { Yap et al., } \\
2020\end{array}$ \\
\hline $\mathrm{Hg}(\mathrm{II})$ & $\begin{array}{l}\text { Sulphur-doped carbon nitride/ } \\
\text { graphene oxide }\end{array}$ & $40 \mathrm{mg} / \mathrm{g}$ & $2 \mathrm{~h}$ & Electrostatic attraction & Li et al., 2020 \\
\hline $\mathrm{Pb}(\mathrm{II})$ & $\mathrm{rGO} / \mathrm{Fe} \mathrm{NPs}$ & $82.4 \%$ & $10 \min$ & $\begin{array}{l}\text { Interaction with active } \\
\text { functional groups }\end{array}$ & $\begin{array}{l}\text { Xiao et al., } \\
2019\end{array}$ \\
\hline $\begin{array}{l}\text { Phenanthrene, } \\
\text { biphenyls }\end{array}$ & GO & $\begin{array}{l}\text { Phenanthrene: } 174.6 \\
\text { mg/g } \\
\text { Biphenyls: } 59 \mathrm{mg} / \mathrm{g}\end{array}$ & - & van der Waals force & $\begin{array}{l}\text { Apul et al., } \\
2013\end{array}$ \\
\hline $\begin{array}{l}\text { TCP, TCB, 2-napthol, } \\
\text { NAPH }\end{array}$ & GO & $\begin{array}{l}\text { TCP: } 3.5 \mathrm{mg} / \mathrm{g} \text { TCB: } \\
\text { 1.6 mg/g } \\
\text { 2-napthol: } 4.2 \mathrm{mg} / \mathrm{g} \\
\text { NAPH: } 0.9 \mathrm{mg} / \mathrm{g}\end{array}$ & $24 \mathrm{~h}$ & $\pi-\pi$ interaction & Pei et al., 2013 \\
\hline MB & Exfoliated GO (EGO) & $17.3 \mathrm{mg} / \mathrm{g}$ & $2 \mathrm{~h}$ & $\begin{array}{l}\text { Electrostatic attraction/van } \\
\text { der Waals force }\end{array}$ & $\begin{array}{l}\text { Ramesha et } \\
\text { al., } 2011\end{array}$ \\
\hline $\begin{array}{l}\text { Methyl violet (MV) } \\
\text { and Rhodamine B, } \\
(\mathrm{RhB})\end{array}$ & EGO & $\begin{array}{l}\mathrm{MV}: 2.5 \mathrm{mg} / \mathrm{g} \\
\mathrm{RhB}: 1.2 \mathrm{mg} / \mathrm{g}\end{array}$ & $\begin{array}{l}\text { MV: } 2 \mathrm{~h} \\
\text { RhB: } 25 \text { min }\end{array}$ & $\begin{array}{l}\text { Electrostatic attraction/ van } \\
\text { der Waals force }\end{array}$ & $\begin{array}{l}\text { Ramesha et } \\
\text { al., } 2011\end{array}$ \\
\hline MB & $\mathrm{rGO} / \mathrm{ZnFe}_{2} \mathrm{O}_{4}$ & $9.7 \mathrm{mg} / \mathrm{g}$ & $30 \min$ & $\begin{array}{l}\text { Bonding with reactive } \\
\text { functional groups }\end{array}$ & $\begin{array}{l}\text { Park et al., } \\
2019\end{array}$ \\
\hline 2,4-Dichlorophenol & $\begin{array}{l}\text { Polysulfone-iron oxide/GO } \\
\text { composite }\end{array}$ & $96.5 \%$ & - & $\begin{array}{l}\text { Oxygen-enriched functional } \\
\text { groups and hydrophilicity }\end{array}$ & $\begin{array}{l}\text { Modi \& } \\
\text { Bellare, } 2020\end{array}$ \\
\hline Rhodamine-B & Polysulfone-GO & $>90 \%$ & $4 \mathrm{~h}$ & Chemisorption & $\begin{array}{l}\text { Zambianchi et } \\
\text { al., } 2017\end{array}$ \\
\hline $\mathrm{MB}, \mathrm{RhB}, \mathrm{MV}$ & $\mathrm{SiO}_{2}$-GO hybrid & $\begin{array}{l}\text { MB: } 300 \mathrm{mg} / \mathrm{g} \\
\text { RhB: } 258 \mathrm{mg} / \mathrm{g} \\
\text { MV: } 178 \mathrm{mg} / \mathrm{g}\end{array}$ & $3 \min$ & Interfacial catalytic process & $\begin{array}{l}\text { Czepa et al., } \\
2020\end{array}$ \\
\hline MB & Sulfated-cellulose GO & $421.90 \mathrm{mg} / \mathrm{g}$ & $<1 \mathrm{~h}$ & Chemisorption & $\begin{array}{l}\text { Wang et al., } \\
2019\end{array}$ \\
\hline 2, 4-Dichlorophenol & $\begin{array}{l}\alpha-\mathrm{Fe}_{2} \mathrm{O}_{3} @ \mathrm{Fe}_{3} \mathrm{O}_{4} \text { shell-core } \\
\text { magnetic nanoparticles and GO }\end{array}$ & $>60 \%$ degradation & $2 \mathrm{~h}$ & $\begin{array}{l}\text { Large surface area } \\
\text { accompanied by pore size } \\
\text { diameter }\end{array}$ & $\begin{array}{l}\text { Pang et al., } \\
2020\end{array}$ \\
\hline
\end{tabular}

1726 "EDTA: Ethylenediaminetetraacetic acid; ‘`‘ indicates unavailability of information on contact time. 
Table S5. List of nanomaterials and their contaminant removal capacities in soil.

\begin{tabular}{|c|c|c|c|c|c|}
\hline Contaminants & Nanomaterials & $\begin{array}{l}\text { Removal capacity } \\
\text { /degradation efficiency }\end{array}$ & Contact time & Mechanism(s) & References \\
\hline $\mathrm{Pb}(\mathrm{II})$ & Nano-hydroxy apatite & $\begin{array}{l}\text { Concentration decreased } \\
\text { by } 3-21 \% \text { in roots and } 13- \\
20 \% \text { in shoots of ryegrass }\end{array}$ & $\begin{array}{l}30 \text { days (rye } \\
\text { grass crop } \\
\text { cycle) }\end{array}$ & $\begin{array}{l}\text { Secretion of tartaric } \\
\text { increased the } \mathrm{Pb} \text { adsorption }\end{array}$ & $\begin{array}{l}\text { Ding et al., } \\
2017\end{array}$ \\
\hline $\begin{array}{l}\mathrm{Pb}(\mathrm{II}), \mathrm{Cu}(\mathrm{II}) \text { and } \\
\mathrm{Zn}(\mathrm{II})\end{array}$ & $\begin{array}{l}\text { Calcium phosphate nanoparticles } \\
\text { (CPNs) }\end{array}$ & $\begin{array}{l}\mathrm{Pb}:>90 \% \\
\mathrm{Cu}: 50 \% \\
\mathrm{Zn}: 50 \%\end{array}$ & $\begin{array}{l}10 \text { days aging } \\
\text { of CPNs and } \\
\text { soil mixture }\end{array}$ & $\begin{array}{l}\text { Insoluble complex } \\
\text { formation between CPNs } \\
\text { and heavy metals }\end{array}$ & $\begin{array}{l}\text { Arenas-Lago } \\
\text { et al., } 2016\end{array}$ \\
\hline $\mathrm{Pb}(\mathrm{II})$ & nZVI/citric acid & $87 \%$ in farmland soil & $4 \mathrm{~h}$ & $\begin{array}{l}\text { Organic acid and metal } \\
\text { chelate formation }\end{array}$ & $\begin{array}{l}\text { Wang et al., } \\
2014\end{array}$ \\
\hline $\mathrm{Cr}(\mathrm{VI})$ & $\begin{array}{l}\text { CMC-stabilized FeS NPs/biochar } \\
\text { composite }\end{array}$ & $\begin{array}{l}11.9 \text { to } 0.63 \mathrm{mg} / \mathrm{L} \text { in the } \\
\text { leachate }\end{array}$ & 180 days & $\begin{array}{l}\text { Strong interaction with } \\
\text { reactive surface sites }\end{array}$ & $\begin{array}{l}\text { Lyu et al., } \\
2018\end{array}$ \\
\hline $\mathrm{Cr}(\mathrm{VI})$ & $\mathrm{nZVI} / \mathrm{Cu}$ & $99 \%$ & $10 \mathrm{~min}$ & $\begin{array}{l}\text { Reduction of } \mathrm{Cr}(\mathrm{VI}) \text { to } \\
\mathrm{Cr}(\mathrm{III}) \text { at low } \mathrm{pH} \text { and } \\
\text { generation of more electrons }\end{array}$ & $\begin{array}{l}\text { Zhu et al., } \\
2016\end{array}$ \\
\hline As & $\mathrm{nZVI}$ & $40.4 \%$ & 3 days & $\begin{array}{l}\text { Bioaccessibility reduced } \\
\text { through surface } \\
\text { complexation }\end{array}$ & $\begin{array}{l}\text { Zhang et al., } \\
2010\end{array}$ \\
\hline As & Green iron oxide NPs & $67.3 \%$ & 120 days & $\begin{array}{l}\text { Covalent bonding and high } \\
\text { Fe content of soil due to } \\
\text { application of Fe-oxide NPs }\end{array}$ & Su et al., 2020 \\
\hline $\mathrm{Pb}(\mathrm{II})$ & Biochar supported nZVI & $54.68 \%$ & 90 days & $\begin{array}{l}\text { Co-precipitation and } \\
\text { secondary Pb-Fe mineral } \\
\text { formation under alkaline } \\
\text { environment }\end{array}$ & $\begin{array}{l}\text { Peng et al., } \\
2019\end{array}$ \\
\hline $\mathrm{Cr}(\mathrm{VI})$ & CMC stabilized FeS NPs & $\begin{array}{l}\text { Leachate } \mathrm{Cr}(\mathrm{VI}) \\
\text { immobilized by }>90 \%\end{array}$ & $42 \mathrm{~h}$ & $\begin{array}{l}\text { Co-precipitation, adsorption } \\
\text { and reduction }\end{array}$ & $\begin{array}{l}\text { Wang et al., } \\
2019\end{array}$ \\
\hline As & nZVI and n-goethite & $\begin{array}{l}\text { nZVI: } 89.5 \% \\
\text { n-goethite: } 82.5 \% \\
\text { (decrease in As } \\
\text { bioavailability) }\end{array}$ & - & Inner-sphere complexation & $\begin{array}{l}\text { Baragaño et } \\
\text { al., } 2020\end{array}$ \\
\hline
\end{tabular}




\begin{tabular}{|c|c|c|c|c|c|}
\hline $\mathrm{Cd}(\mathrm{II})$ & nZVI/palm BC & $\begin{array}{l}\text { Pronounced } \\
\text { immobilization in soil }\end{array}$ & $\begin{array}{l}120 \text { days } \\
\text { (Rice life } \\
\text { cycle) }\end{array}$ & Sorption and precipitation & $\begin{array}{l}\text { Qiao et al., } \\
2018\end{array}$ \\
\hline $\mathrm{Sb}(\mathrm{V})$ & $\mathrm{nZVI}$ & $>90 \%$ & $6-8 \mathrm{~min}$ & Chemisorption & $\begin{array}{l}\text { Dorjee et al., } \\
2014\end{array}$ \\
\hline $\mathrm{Cd}(\mathrm{II})$ & GO & $103.3 \mathrm{mg} / \mathrm{g}$ & 60 days & $\begin{array}{l}\text { Adsorption via chelation to } \\
\text { form stable Cd-complexes }\end{array}$ & $\begin{array}{l}\text { Xiong et al., } \\
2018\end{array}$ \\
\hline $\begin{array}{l}\text { Decabromodiphenyl } \\
\text { ether (BDE-209) }\end{array}$ & $\mathrm{Ni} / \mathrm{Fe}$ BNPs & $72 \%$ & $72 \mathrm{~h}$ & $\begin{array}{l}\text { Mass transfer and } \\
\text { Generation of active } \mathrm{H}_{2} \\
\text { species due to } \mathrm{Fe} \text { corrosion } \\
\text { in water }\end{array}$ & $\begin{array}{l}\text { Xie et al., } \\
2014\end{array}$ \\
\hline $\begin{array}{l}\text { Decabromodiphenyl } \\
\text { ether (BDE-209) }\end{array}$ & $\begin{array}{l}\text { nZVI immobilized in mesoporous } \\
\text { silica microspheres covered with } \\
\text { FeOOH }\left(\mathrm{SiO}_{2} @ \mathrm{FeOOH} @ \mathrm{Fe}\right)\end{array}$ & $78 \%$ & $120 \mathrm{~h}$ & Corrosion of $\mathrm{Fe}$ & $\begin{array}{l}\text { Xie et al., } \\
2016\end{array}$ \\
\hline $\begin{array}{l}\text { Polychlorinated } \\
\text { biphenyls (PCB) }\end{array}$ & nZVI & $83 \%$ & 5 days & $\begin{array}{l}\text { Hydro-dechlorination by } \\
\text { generation of } \mathrm{H}^{+} \text {in anode }\end{array}$ & $\begin{array}{l}\text { Gomes et al., } \\
2015\end{array}$ \\
\hline PAHs & $\mathrm{Fe}_{3} \mathrm{O}_{4} /$ persulfate & $75 \%$ & $24 \mathrm{~h}$ & $\begin{array}{l}\text { Generation of free radicals } \\
\text { or reactive oxygen species }\end{array}$ & $\begin{array}{l}\text { Dong et al., } \\
2018\end{array}$ \\
\hline PAHs & $\mathrm{nZVI} / \mathrm{BC}$ & $40 \%$ & $\begin{array}{l}30 \\
\text { days }\end{array}$ & $\begin{array}{l}\text { Active sites and functional } \\
\text { groups of biochar }\end{array}$ & $\begin{array}{l}\text { Oleszczuk \& } \\
\text { Kołtowski, } \\
2017\end{array}$ \\
\hline Chlorpyriphos & $\begin{array}{l}\text { Laccase immobilized iron oxide } \\
\text { NPs }\end{array}$ & $\mathrm{K}_{\mathrm{d}}: 112.3 \mathrm{~L} / \mathrm{kg}$ & 30 days & $\begin{array}{l}\text { Hydrolysis of chlorpyriphos } \\
\text { due to presence of } \mathrm{Cu} \text { in } \\
\text { laccase molecules }\end{array}$ & $\begin{array}{l}\text { Das et al., } \\
2020\end{array}$ \\
\hline Sulfamethazine & nZVI/corn stalk biochar & $74 \%$ & $12 \mathrm{~h}$ & Fenton like degradation & $\begin{array}{l}\text { Deng et al., } \\
2018\end{array}$ \\
\hline Ibuprofen & nZVI using grape vine leaf extract & $66 \%$ & $73 \mathrm{~h}$ & $\begin{array}{l}\text { Low } \mathrm{pH} \text { and faster } \\
\text { reactivity }\end{array}$ & $\begin{array}{l}\text { Machado et } \\
\text { al., } 2013\end{array}$ \\
\hline
\end{tabular}

‘_ indicates unavailability of information on contact time. 


\section{References}

1731

1732

1733

1734

1735

1736

1737

1738

1739

1740

1741

1742

1743

1744

1745

1746

1747

1748

1749

1750

1751

1752

1753

1754

1755

1756

1757

1758

1759

1760

1761

1762

1763

1764

1765

1766

1767

1768

1769

1770

1771

1772

1773

1774

1775

1776

1777

Addo Ntim, S., Mitra, S. 2011. Removal of trace arsenic to meet drinking water standards using iron oxide coated multiwall carbon nanotubes. Journal of Chemical \& Engineering Data, 56(5), 20772083.

Affonso, L.N., Marques, J.L., Lima, V.V.C., Gonçalves, J.O., Barbosa, S.C., Primel, E.G., Burgo, T.A.L., Dotto, G.L., Pinto, L.A.A., Cadaval, T.R.S. 2020. Removal of fluoride from fertilizer industry effluent using carbon nanotubes stabilized in chitosan sponge. Journal of Hazardous Materials, 388, 122042.

Ahmadi, S.J., Sadjadi, S., Hosseinpour, M. 2012. Adsorption behavior of toxic metal ions on nanostructured $\mathrm{CuO}$ granules. Separation Science and Technology, 47(7), 1063-1069.

Ai, L., Jiang, J. 2012. Removal of methylene blue from aqueous solution with self-assembled cylindrical graphene-carbon nanotube hybrid. Chemical Engineering Journal, 192, 156-163.

Ain, Q.-U., Farooq, M.U., Jalees, M.I. 2020. Application of magnetic graphene oxide for water purification: heavy metals removal and disinfection. Journal of Water Process Engineering, 33, 101044.

Almeelbi, T., Bezbaruah, A. 2012. Aqueous phosphate removal using nanoscale zero-valent iron. Journal of Nanoparticle Research, 14(7), 900.

Alves, D.C.S., Gonçalves, J.O., Coseglio, B.B., Burgo, T.A.L., Dotto, G.L., Pinto, L.A.A., Cadaval, T.R.S. 2019. Adsorption of phenol onto chitosan hydrogel scaffold modified with carbon nanotubes. Journal of Environmental Chemical Engineering, 7(6), 103460.

Apul, O.G., Wang, Q., Zhou, Y., Karanfil, T. 2013. Adsorption of aromatic organic contaminants by graphene nanosheets: Comparison with carbon nanotubes and activated carbon. Water Research, 47(4), 1648-1654.

Arenas-Lago, D., Rodríguez-Seijo, A., Lago-Vila, M., Couce, L.A., Vega, F.A. 2016. Using $\mathrm{Ca}_{3}\left(\mathrm{PO}_{4}\right)_{2}$ nanoparticles to reduce metal mobility in shooting range soils. Science of The Total Environment, 571, 1136-1146.

Bakhsh, E.M., Ali, F., Khan, S.B., Marwani, H.M., Danish, E.Y., Asiri, A.M. 2019. Copper nanoparticles embedded chitosan for efficient detection and reduction of nitroaniline. International Journal of Biological Macromolecules, 131, 666-675.

Bandaru, N.M., Reta, N., Dalal, H., Ellis, A.V., Shapter, J., Voelcker, N.H. 2013. Enhanced adsorption of mercury ions on thiol derivatized single wall carbon nanotubes. Journal of Hazardous Materials, 261, 534-541.

Baragaño, D., Alonso, J., Gallego, J.R., Lobo, M.C., Gil-Díaz, M. 2020. Zero valent iron and goethite nanoparticles as new promising remediation techniques for As-polluted soils. Chemosphere, 238, 124624.

Bezbaruah, A.N., Thompson, J.M., Chisholm, B.J. 2009. Remediation of alachlor and atrazine contaminated water with zero-valent iron nanoparticles. Journal of Environmental Science and Health, Part B, 44(6), 518-524.

Bin, Q., Lin, B., Zhu, K., Shen, Y., Man, Y., Wang, B., Lai, C., Chen, W. 2020. Superior trichloroethylene removal from water by sulfide-modified nanoscale zero-valent iron/graphene aerogel composite. Journal of Environmental Sciences, 88, 90-102.

Calderon, B., Fullana, A. 2015. Heavy metal release due to aging effect during zero valent iron nanoparticles remediation. Water Research, 83, 1-9.

Crane, R.A., Sapsford, D.J. 2018. Sorption and fractionation of rare earth element ions onto nanoscale zerovalent iron particles. Chemical Engineering Journal, 345, 126-137.

Cui, L., Wang, Y., Gao, L., Hu, L., Yan, L., Wei, Q., Du, B. 2015. EDTA functionalized magnetic graphene oxide for removal of $\mathrm{Pb}(\mathrm{II}), \mathrm{Hg}(\mathrm{II})$ and $\mathrm{Cu}(\mathrm{II})$ in water treatment: Adsorption mechanism and separation property. Chemical Engineering Journal, 281, 1-10. 
1778

1779

1780

1781

1782

1783

1784

1785

1786

1787

1788

1789

1790

1791

1792

1793

1794

1795

1796

1797

1798

1799

1800

1801

1802

1803

1804

1805

1806

1807

1808

1809

1810

1811

1812

1813

1814

1815

1816

1817

1818

1819

1820

1821

1822

1823

1824

1825

1826

1827

1828

Czepa, W., Pakulski, D., Witomska, S., Patroniak, V., Ciesielski, A., Samorì, P. 2020. Graphene oxidemesoporous $\mathrm{SiO}_{2}$ hybrid composite for fast and efficient removal of organic cationic contaminants. Carbon, 158, 193-201.

Das, A., Jaswal, V., Yogalakshmi, K.N. 2020. Degradation of chlorpyrifos in soil using laccase immobilized iron oxide nanoparticles and their competent role in deterring the mobility of chlorpyrifos. Chemosphere, 246, 125676.

Dat, T.Q., Ha, N.T., Thin, P.V., Tung, N.V., Hung, D.Q. 2018. Synthesis of RGO/CF/PANI Magnetic Composites for Effective Adsorption of Uranium. IEEE Transactions on Magnetics, 54(6), 1-6.

Deng, J., Dong, H., Zhang, C., Jiang, Z., Cheng, Y., Hou, K., Zhang, L., Fan, C. 2018. Nanoscale zerovalent iron/biochar composite as an activator for Fenton-like removal of sulfamethazine. Separation and Purification Technology, 202, 130-137.

Deng, J., Shao, Y., Gao, N., Deng, Y., Tan, C., Zhou, S., Hu, X. 2012. Multiwalled carbon nanotubes as adsorbents for removal of herbicide diuron from aqueous solution. Chemical Engineering Journal, 193-194, 339-347.

Ding, L., Li, J., Liu, W., Zuo, Q., Liang, S.-X. 2017. Influence of nano-hydroxyapatite on the metal bioavailability, plant metal accumulation and root exudates of Ryegrass for phytoremediation in lead-polluted soil. International journal of environmental research and public health, 14(5), 532.

Dong, C.-D., Tsai, M.-L., Chen, C.-W., Hung, C.-M. 2018. Remediation and cytotoxicity study of polycyclic aromatic hydrocarbon-contaminated marine sediments using synthesized iron oxidecarbon composite. Environmental Science and Pollution Research, 25(6), 5243-5253.

Dorjee, P., Amarasiriwardena, D., Xing, B. 2014. Antimony adsorption by zero-valent iron nanoparticles (nZVI): Ion chromatography-inductively coupled plasma mass spectrometry (IC-ICP-MS) study. Microchemical Journal, 116, 15-23.

Du, Y., Dai, M., Cao, J., Peng, C., Ali, I., Naz, I., Li, J. 2020. Efficient removal of acid orange 7 using a porous adsorbent-supported zero-valent iron as a synergistic catalyst in advanced oxidation process. Chemosphere, 244, 125522.

ElShafei, G.M.S., Yehia, F.Z., Dimitry, O.I.H., Badawi, A.M., Eshaq, G. 2014. Ultrasonic assistedFenton-like degradation of nitrobenzene at neutral $\mathrm{pH}$ using nanosized oxides of $\mathrm{Fe}$ and $\mathrm{Cu}$. Ultrasonics Sonochemistry, 21(4), 1358-1365.

El-Temsah, Y.S., Sevcu, A., Bobcikova, K., Cernik, M., Joner, E.J. 2016. DDT degradation efficiency and ecotoxicological effects of two types of nano-sized zero-valent iron (nZVI) in water and soil. Chemosphere, 144, 2221-2228.

Elwakeel, K.Z., Guibal, E. 2015. Arsenic(V) sorption using chitosan/Cu(OH) 2 and chitosan/CuO composite sorbents. Carbohydrate Polymers, 134, 190-204.

Esmaeili, A., Khoshnevisan, N. 2016. Optimization of process parameters for removal of heavy metals by biomass of $\mathrm{Cu}$ and $\mathrm{Co}-$ doped alginate-coated chitosan nanoparticles. Bioresource Technology, 218, 650-658.

Fang, F., Kong, L., Huang, J., Wu, S., Zhang, K., Wang, X., Sun, B., Jin, Z., Wang, J., Huang, X.-J., Liu, J. 2014. Removal of cobalt ions from aqueous solution by an amination graphene oxide nanocomposite. Journal of Hazardous Materials, 270, 1-10.

Fei, X., Li, F., Cao, L., Jia, G., Zhang, M. 2015. Adsorption and photocatalytic performance of cuprous oxide/titania composite in the degradation of acid red B. Materials Science in Semiconductor Processing, 33, 9-15.

Feng, L., Cao, M., Ma, X., Zhu, Y., Hu, C. 2012. Superparamagnetic high-surface-area $\mathrm{Fe}_{3} \mathrm{O}_{4}$ nanoparticles as adsorbents for arsenic removal. Journal of Hazardous Materials, 217-218, 439446.

Gomes, H.I., Dias-Ferreira, C., Ottosen, L.M., Ribeiro, A.B. 2015. Electroremediation of PCB contaminated soil combined with iron nanoparticles: Effect of the soil type. Chemosphere, 131, 157-163.

Gonçalves, J.O., da Silva, K.A., Rios, E.C., Crispim, M.M., Dotto, G.L., de Almeida Pinto, L.A. 2020. Chitosan hydrogel scaffold modified with carbon nanotubes and its application for food dyes 
removal in single and binary aqueous systems. International Journal of Biological Macromolecules, 142, 85-93.

Gopal, G., Sankar, H., Natarajan, C., Mukherjee, A. 2020. Tetracycline removal using green synthesized bimetallic $\mathrm{nZVI-Cu}$ and bentonite supported green $\mathrm{nZVI-Cu}$ nanocomposite: A comparative study. Journal of Environmental Management, 254, 109812.

Gu, W., Li, X., Xing, M., Fang, W., Wu, D. 2018. Removal of phosphate from water by aminefunctionalized copper ferrite chelated with La(III). Science of The Total Environment, 619-620, 42-48.

Gupta, A., Vidyarthi, S.R., Sankararamakrishnan, N. 2014. Enhanced sorption of mercury from compact fluorescent bulbs and contaminated water streams using functionalized multiwalled carbon nanotubes. Journal of Hazardous Materials, 274, 132-144.

Gupta, V.K., Agarwal, S., Saleh, T.A. 2011. Chromium removal by combining the magnetic properties of iron oxide with adsorption properties of carbon nanotubes. Water Research, 45(6), 2207-2212.

Gupta, V.K., Chandra, R., Tyagi, I., Verma, M. 2016. Removal of hexavalent chromium ions using CuO nanoparticles for water purification applications. Journal of Colloid and Interface Science, 478, 54-62.

Hu, H., Sun, L., Jiang, B., Wu, H., Huang, Q., Chen, X. 2018. Low concentration Re(VII) recovery from acidic solution by $\mathrm{Cu}$-biochar composite prepared from bamboo (Acidosasa longiligula) shoot shell. Minerals Engineering, 124, 123-136.

Hua, Y., Wang, W., Huang, X., Gu, T., Ding, D., Ling, L., Zhang, W.-x. 2018. Effect of bicarbonate on aging and reactivity of nanoscale zerovalent iron (nZVI) toward uranium removal. Chemosphere, 201, 603-611.

Huang, C.-C., Lo, S.-L., Lien, H.-L. 2012. Zero-valent copper nanoparticles for effective dechlorination of dichloromethane using sodium borohydride as a reductant. Chemical Engineering Journal, 203, 95-100.

Huang, J., Cao, Y., Qin, B., Zhong, G., Zhang, J., Yu, H., Wang, H., Peng, F. 2019. Highly efficient and acid-corrosion resistant nitrogen doped magnetic carbon nanotubes for the hexavalent chromium removal with subsequent reutilization. Chemical Engineering Journal, 361, 547-558.

Huong, P.T.L., Huy, L.T., Phan, V.N., Huy, T.Q., Nam, M.H., Lam, V.D., Le, A.-T. 2016. Application of graphene oxide- $\mathrm{MnFe}_{2} \mathrm{O}_{4}$ magnetic nanohybrids as magnetically separable adsorbent for highly efficient removal of arsenic from water. Journal of Electronic Materials, 45(5), 2372-2380.

Husein, D.Z., Hassanien, R., Al-Hakkani, M.F. 2019. Green-synthesized copper nano-adsorbent for the removal of pharmaceutical pollutants from real wastewater samples. Heliyon, 5(8), e02339.

Jung, C., Son, A., Her, N., Zoh, K.-D., Cho, J., Yoon, Y. 2015. Removal of endocrine disrupting compounds, pharmaceuticals, and personal care products in water using carbon nanotubes: A review. Journal of Industrial and Engineering Chemistry, 27, 1-11.

Khamirchi, R., Hosseini-Bandegharaei, A., Alahabadi, A., Sivamani, S., Rahmani-Sani, A., Shahryari, T., Anastopoulos, I., Miri, M., Tran, H.N. 2018. Adsorption property of Br-PADAP-impregnated multiwall carbon nanotubes towards uranium and its performance in the selective separation and determination of uranium in different environmental samples. Ecotoxicology and Environmental Safety, 150, 136-143.

Lan, J., Cheng, Y., Zhao, Z. 2014. Effective organochlorine pesticides removal from aqueous systems by magnetic nanospheres coated with polystyrene. Journal of Wuhan University of TechnologyMater. Sci. Ed., 29(1), 168-173.

Leng, Y., Guo, W., Su, S., Yi, C., Xing, L. 2012. Removal of antimony(III) from aqueous solution by graphene as an adsorbent. Chemical Engineering Journal, 211-212, 406-411.

Li, M., Wang, B., Yang, M., Li, Q., Calatayud, D.G., Zhang, S., Wang, H., Wang, L., Mao, B. 2020. Promoting mercury removal from desulfurization slurry via S-doped carbon nitride/graphene oxide 3D hierarchical framework. Separation and Purification Technology, 239, 116515.

Liang, J., Liu, J., Yuan, X., Dong, H., Zeng, G., Wu, H., Wang, H., Liu, J., Hua, S., Zhang, S., Yu, Z., He, X., He, Y. 2015. Facile synthesis of alumina-decorated multi-walled carbon nanotubes for 
simultaneous adsorption of cadmium ion and trichloroethylene. Chemical Engineering Journal, 273, 101-110.

Lin, J.-H., Wu, S.-W., Kuo, C.-Y. 2014. Degradation of gaseous 1,2-dichloroethane using a hybrid cuprous oxide catalyst. Process Safety and Environmental Protection, 92(5), 442-446.

Lin, K.-S., Mdlovu, N.V., Chen, C.-Y., Chiang, C.-L., Dehvari, K. 2018. Degradation of TCE, PCE, and $1,2-$ DCE DNAPLs in contaminated groundwater using polyethylenimine-modified zero-valent iron nanoparticles. Journal of Cleaner Production, 175, 456-466.

Liu, Z., Ding, C., Gao, P., Xu, Y., Sun, Y., Wen, X., Dai, J., Fei, Z. 2020. Enhanced dechlorination of 2,6-dichlorophenol by carbon nanotubes supported Fe/Ni nanoparticles: Characterization, influencing factors, and kinetics. Colloids and Surfaces A: Physicochemical and Engineering Aspects, 585, 124089.

Lu, C., Chiu, H., Liu, C. 2006. Removal of zinc(II) from aqueous solution by purified carbon nanotubes: kinetics and equilibrium studies. Industrial \& Engineering Chemistry Research, 45(8), 28502855.

Luan, H., Teychene, B., Huang, H. 2019. Efficient removal of As(III) by Cu nanoparticles intercalated in carbon nanotube membranes for drinking water treatment. Chemical Engineering Journal, 355, 341-350.

Luo, X., Guo, X., Xia, X., Zhang, X., Ma, N., Leng, S., Ullah, S., Ayalew, Z.M. 2020. Rapid and longeffective removal of phosphate from water by zero-valent iron in combination with hypochlorite (ZVI/NaClO). Chemical Engineering Journal, 382, 122835.

Lyu, H., Zhao, H., Tang, J., Gong, Y., Huang, Y., Wu, Q., Gao, B. 2018. Immobilization of hexavalent chromium in contaminated soils using biochar supported nanoscale iron sulfide composite. Chemosphere, 194, 360-369.

Machado, S., Stawiński, W., Slonina, P., Pinto, A.R., Grosso, J.P., Nouws, H.P.A., Albergaria, J.T., Delerue-Matos, C. 2013. Application of green zero-valent iron nanoparticles to the remediation of soils contaminated with ibuprofen. Science of The Total Environment, 461-462, 323-329.

Mahanty, S., Bakshi, M., Ghosh, S., Gaine, T., Chatterjee, S., Bhattacharyya, S., Das, S., Das, P., Chaudhuri, P. 2019. Mycosynthesis of iron oxide nanoparticles using manglicolous fungi isolated from Indian sundarbans and its application for the treatment of chromium containing solution: Synthesis, adsorption isotherm, kinetics and thermodynamics study. Environmental Nanotechnology, Monitoring \& Management, 12, 100276.

Mahmoodian, H., Moradi, O., Shariatzadeha, B., Salehf, T.A., Tyagi, I., Maity, A., Asif, M., Gupta, V.K. 2015. Enhanced removal of methyl orange from aqueous solutions by poly HEMA-chitosanMWCNT nano-composite. Journal of Molecular Liquids, 202, 189-198.

Manilo, M.V., Choma, Z.Z., Barany, S. 2017. Comparative study of Cr(III) adsorption by carbon nanotubes and active carbons. Colloid Journal, 79(2), 212-218.

Mansouriieh, N., Sohrabi, M.R., Khosravi, M. 2019. Optimization of profenofos organophosphorus pesticide degradation by zero-valent bimetallic nanoparticles using response surface methodology. Arabian Journal of Chemistry, 12(8), 2524-2532.

Mao, Q., Zhou, Y., Yang, Y., Zhang, J., Liang, L., Wang, H., Luo, S., Luo, L., Jeyakumar, P., Ok, Y.S., Rizwan, M. 2019. Experimental and theoretical aspects of biochar-supported nanoscale zerovalent iron activating $\mathrm{H}_{2} \mathrm{O}_{2}$ for ciprofloxacin removal from aqueous solution. Journal of Hazardous Materials, 380, 120848.

Mao, Y., Xi, Z., Wang, W., Ma, C., Yue, Q. 2015. Kinetics of Solvent Blue and Reactive Yellow removal using microwave radiation in combination with nanoscale zero-valent iron. Journal of Environmental Sciences, 30, 164-172.

Masunga, N., Mmelesi, O.K., Kefeni, K.K., Mamba, B.B. 2019. Recent advances in copper ferrite nanoparticles and nanocomposites synthesis, magnetic properties and application in water treatment: Review. Journal of Environmental Chemical Engineering, 7(3), 103179. 
1960

1961

1962

1963

1964

1965

1966

1967

1968

1969

1970

1971

1972

1973

1974

1975

1976

1977

1978

Mdlovu, N.V., Lin, K.-S., Chen, Z.-W., Liu, Y.-J., Mdlovu, N.B. 2020. Treatment of simulated chromium-contaminated wastewater using polyethylenimine-modified zero-valent iron nanoparticles. Journal of the Taiwan Institute of Chemical Engineers, 108, 92-101.

Mishra, A.K., Ramaprabhu, S. 2010. Magnetite decorated multiwalled carbon nanotube based supercapacitor for arsenic removal and desalination of seawater. The Journal of Physical Chemistry $C, \mathbf{1 1 4}(6), 2583-2590$.

Modi, A., Bellare, J. 2020. Efficient removal of 2,4-dichlorophenol from contaminated water and alleviation of membrane fouling by high flux polysulfone-iron oxide/graphene oxide composite hollow fiber membranes. Journal of Water Process Engineering, 33, 101113.

Mofradnia, S.R., Ashouri, R., Tavakoli, Z., Shahmoradi, F., Rashedi, H., Yazdian, F., Tavakoli, J. 2019. Effect of zero-valent iron/starch nanoparticle on nitrate removal using MD simulation. International Journal of Biological Macromolecules, 121, 727-733.

Morillo, D., Pérez, G., Valiente, M. 2015. Efficient arsenic(V) and arsenic(III) removal from acidic solutions with Novel Forager Sponge-loaded superparamagnetic iron oxide nanoparticles. Journal of Colloid and Interface Science, 453, 132-141.

Mortazavian, S., Jones-Lepp, T., Bae, J.-H., Chun, D., Bandala, E.R., Moon, J. 2019. Heat-treated biochar impregnated with zero-valent iron nanoparticles for organic contaminants removal from aqueous phase: Material characterizations and kinetic studies. Journal of Industrial and Engineering Chemistry, 76, 197-214.

Nairat, M., Shahwan, T., Eroğlu, A.E., Fuchs, H. 2015. Incorporation of iron nanoparticles into clinoptilolite and its application for the removal of cationic and anionic dyes. Journal of Industrial and Engineering Chemistry, 21, 1143-1151.

Nekouei, F., Nekouei, S., Tyagi, I., Gupta, V.K. 2015. Kinetic, thermodynamic and isotherm studies for acid blue 129 removal from liquids using copper oxide nanoparticle-modified activated carbon as a novel adsorbent. Journal of Molecular Liquids, 201, 124-133.

Nwanya, A.C., Razanamahandry, L.C., Bashir, A.K.H., Ikpo, C.O., Nwanya, S.C., Botha, S., Ntwampe, S.K.O., Ezema, F.I., Iwuoha, E.I., Maaza, M. 2019. Industrial textile effluent treatment and antibacterial effectiveness of Zea mays L. Dry husk mediated bio-synthesized copper oxide nanoparticles. Journal of Hazardous Materials, 375, 281-289.

Nyairo, W.N., Eker, Y.R., Kowenje, C., Akin, I., Bingol, H., Tor, A., Ongeri, D.M. 2018. Efficient adsorption of lead (II) and copper (II) from aqueous phase using oxidized multiwalled carbon nanotubes/polypyrrole composite. Separation Science and Technology, 53(10), 1498-1510.

Oleszczuk, P., Kołtowski, M. 2017. Effect of co-application of nano-zero valent iron and biochar on the total and freely dissolved polycyclic aromatic hydrocarbons removal and toxicity of contaminated soils. Chemosphere, 168, 1467-1476.

Pang, Y., Zhou, Y., Luo, K., Zhang, Z., Yue, R., Li, X., Lei, M. 2020. Activation of persulfate by stability-enhanced magnetic graphene oxide for the removal of 2,4-dichlorophenol. Science of The Total Environment, 707, 135656.

Park, C.M., Kim, Y.M., Kim, K.-H., Wang, D., Su, C., Yoon, Y. 2019. Potential utility of graphene-based nano spinel ferrites as adsorbent and photocatalyst for removing organic/inorganic contaminants from aqueous solutions: A mini review. Chemosphere, 221, 392-402.

Peeters, K., Lespes, G., Milačič, R., Ščančar, J. 2015. Adsorption and degradation processes of tributyltin and trimethyltin in landfill leachates treated with iron nanoparticles. Environmental Research, 142, 511-521.

Pei, Z., Li, L., Sun, L., Zhang, S., Shan, X.-q., Yang, S., Wen, B. 2013. Adsorption characteristics of 1,2,4-trichlorobenzene, 2,4,6-trichlorophenol, 2-naphthol and naphthalene on graphene and graphene oxide. Carbon, 51, 156-163.

Peng, D., Wu, B., Tan, H., Hou, S., Liu, M., Tang, H., Yu, J., Xu, H. 2019. Effect of multiple iron-based nanoparticles on availability of lead and iron, and micro-ecology in lead contaminated soil. Chemosphere, 228, 44-53. 
2010

2011

2012

2013

2014

2015

2016

2017

2018

2019

2020

2021

2022

2023

2024

2025

2026

2027

2028

2029

Prasad, K.S., Gandhi, P., Selvaraj, K. 2014. Synthesis of green nano iron particles (GnIP) and their application in adsorptive removal of $\mathrm{As}(\mathrm{III})$ and $\mathrm{As}(\mathrm{V})$ from aqueous solution. Applied Surface Science, 317, 1052-1059.

Qiao, J.-t., Liu, T.-X., Wang, X.-q., Li, F.-b., Lv, Y.-h., Cui, J.-h., Zeng, X.-d., Yuan, Y.-z., Liu, C.-p. 2018. Simultaneous alleviation of cadmium and arsenic accumulation in rice by applying zerovalent iron and biochar to contaminated paddy soils. Chemosphere, 195, 260-271.

Rajesh, R., Iyer, S.S., Ezhilan, J., Kumar, S.S., Venkatesan, R. 2016. Graphene oxide supported copper oxide nanoneedles: An efficient hybrid material for removal of toxic azo dyes. Spectrochimica Acta Part A: Molecular and Biomolecular Spectroscopy, 166, 49-55.

Ramesha, G.K., Vijaya Kumara, A., Muralidhara, H.B., Sampath, S. 2011. Graphene and graphene oxide as effective adsorbents toward anionic and cationic dyes. Journal of Colloid and Interface Science, 361(1), 270-277.

Raut, S.S., Kamble, S.P., Kulkarni, P.S. 2016. Efficacy of zero-valent copper $\left(\mathrm{Cu}^{0}\right)$ nanoparticles and reducing agents for dechlorination of mono chloroaromatics. Chemosphere, 159, 359-366.

Sadegh, H., Zare, K., Maazinejad, B., Shahryari-ghoshekandi, R., Tyagi, I., Agarwal, S., Gupta, V.K. 2016. Synthesis of MWCNT-COOH-Cysteamine composite and its application for dye removal. Journal of Molecular Liquids, 215, 221-228.

Salam, M.A. 2017. Preparation and characterization of chitin/magnetite/multiwalled carbon nanotubes magnetic nanocomposite for toxic hexavalent chromium removal from solution. Journal of Molecular Liquids, 233, 197-202.

Saleh, T.A., Sarı, A., Tuzen, M. 2019. Carbon nanotubes grafted with poly(trimesoyl, mphenylenediamine) for enhanced removal of phenol. Journal of Environmental Management, 252, 109660.

Senthil Kumar, P., Selvakumar, M., Babu, S.G., Jaganathan, S.K., Karuthapandian, S., Chattopadhyay, S. 2015. Novel $\mathrm{CuO} /$ chitosan nanocomposite thin film: facile hand-picking recoverable, efficient and reusable heterogeneous photocatalyst. RSC Advances, 5(71), 57493-57501.

Shao, Y., Gao, Y., Yue, Q., Kong, W., Gao, B., Wang, W., Jiang, W. 2020. Degradation of chlortetracycline with simultaneous removal of copper (II) from aqueous solution using wheat straw-supported nanoscale zero-valent iron. Chemical Engineering Journal, 379, 122384.

Simamora, A.J., Hsiung, T.L., Chang, F.C., Yang, T.C., Liao, C.Y., Wang, H.P. 2012. Photocatalytic splitting of seawater and degradation of methylene blue on $\mathrm{CuO} /$ nano $\mathrm{TiO}_{2}$. International Journal of Hydrogen Energy, 37(18), 13855-13858.

Singha Deb, A.K., Dwivedi, V., Dasgupta, K., Musharaf Ali, S., Shenoy, K.T. 2017. Novel amidoamine functionalized multi-walled carbon nanotubes for removal of mercury(II) ions from wastewater: Combined experimental and density functional theoretical approach. Chemical Engineering Journal, 313, 899-911.

Sohrabi, S., Akhlaghian, F. 2016. Modeling and optimization of phenol degradation over copper-doped titanium dioxide photocatalyst using response surface methodology. Process Safety and Environmental Protection, 99, 120-128.

Sotelo, J.L., Rodríguez, A.R., Mateos, M.M., Hernández, S.D., Torrellas, S.A., Rodríguez, J.G. 2012. Adsorption of pharmaceutical compounds and an endocrine disruptor from aqueous solutions by carbon materials. Journal of Environmental Science and Health, Part B, 47(7), 640-652.

Stevenson, L.M., Adeleye, A.S., Su, Y., Zhang, Y., Keller, A.A., Nisbet, R.M. 2017. Remediation of cadmium toxicity by sulfidized nano-iron: the importance of organic material. ACS Nano, 11(10), 10558-10567.

Su, B., Lin, J., Owens, G., Chen, Z. 2020. Impact of green synthesized iron oxide nanoparticles on the distribution and transformation of As species in contaminated soil. Environmental Pollution, 258, 113668.

Sun, T., Zhao, Z., Liang, Z., Liu, J., Shi, W., Cui, F. 2017. Efficient As(III) removal by magnetic CuO$\mathrm{Fe}_{3} \mathrm{O}_{4}$ nanoparticles through photo-oxidation and adsorption under light irradiation. Journal of Colloid and Interface Science, 495, 168-177. 
2060

2061

2062

2063

2064

2065

2066

2067

2068

2069

2070

2071

2072

2073

2074

2075

2076

2077

2078

2079

2080

Sun, Y., Wang, Q., Chen, C., Tan, X., Wang, X. 2012. Interaction between Eu(III) and graphene oxide nanosheets investigated by batch and extended X-ray absorption fine structure spectroscopy and by modeling techniques. Environmental Science \& Technology, 46(11), 6020-6027.

Tan, P., Sun, J., Hu, Y., Fang, Z., Bi, Q., Chen, Y., Cheng, J. 2015. Adsorption of $\mathrm{Cu}^{2+}, \mathrm{Cd}^{2+}$ and $\mathrm{Ni}^{2+}$ from aqueous single metal solutions on graphene oxide membranes. Journal of Hazardous Materials, 297, 251-260.

Tofighy, M.A., Mohammadi, T. 2011. Adsorption of divalent heavy metal ions from water using carbon nanotube sheets. Journal of Hazardous Materials, 185(1), 140-147.

Tomašević, A., Kiss, E., Petrović, S., Mijin, D. 2010. Study on the photocatalytic degradation of insecticide methomyl in water. Desalination, 262(1), 228-234.

Usman, M., Ahmed, A., Yu, B., Peng, Q., Shen, Y., Cong, H. 2019. Photocatalytic potential of bioengineered copper nanoparticles synthesized from Ficus carica extract for the degradation of toxic organic dye from waste water: Growth mechanism and study of parameter affecting the degradation performance. Materials Research Bulletin, 120, 110583.

Üzüm, Ç., Shahwan, T., Eroğlu, A.E., Lieberwirth, I., Scott, T.B., Hallam, K.R. 2008. Application of zero-valent iron nanoparticles for the removal of aqueous $\mathrm{Co}^{2+}$ ions under various experimental conditions. Chemical Engineering Journal, 144(2), 213-220.

Verma, B., Balomajumder, C. 2020. Surface modification of one-dimensional carbon nanotubes: a review for the management of heavy metals in wastewater. Environmental Technology \& Innovation, 17, 100596.

Vilardi, G., Mpouras, T., Dermatas, D., Verdone, N., Polydera, A., Di Palma, L. 2018. Nanomaterials application for heavy metals recovery from polluted water: The combination of nano zero-valent iron and carbon nanotubes. Competitive adsorption non-linear modeling. Chemosphere, 201, 716729.

Vuković, G.D., Marinković, A.D., Čolić, M., Ristić, M.Đ., Aleksić, R., Perić-Grujić, A.A., Uskoković, P.S. 2010. Removal of cadmium from aqueous solutions by oxidized and ethylenediaminefunctionalized multi-walled carbon nanotubes. Chemical Engineering Journal, 157(1), 238-248.

Wang, B., Dong, H., Li, L., Wang, Y., Ning, Q., Tang, L., Zeng, G. 2020. Influence of different cocontaminants on trichloroethylene removal by sulfide-modified nanoscale zero-valent iron. Chemical Engineering Journal, 381, 122773.

Wang, G., Zhang, S., Xu, X., Li, T., Li, Y., Deng, O., Gong, G. 2014. Efficiency of nanoscale zero-valent iron on the enhanced low molecular weight organic acid removal $\mathrm{Pb}$ from contaminated soil. Chemosphere, 117, 617-624.

Wang, H., Yuan, X., Wu, Y., Huang, H., Zeng, G., Liu, Y., Wang, X., Lin, N., Qi, Y. 2013. Adsorption characteristics and behaviors of graphene oxide for $\mathrm{Zn}$ (II) removal from aqueous solution. Applied Surface Science, 279, 432-440.

Wang, S., Ma, X., Zheng, P. 2019. Sulfo-functional 3D porous cellulose/graphene oxide composites for highly efficient removal of methylene blue and tetracycline from water. International Journal of Biological Macromolecules, 140, 119-128.

Wang, T., Liu, Y., Wang, J., Wang, X., Liu, B., Wang, Y. 2019. In-situ remediation of hexavalent chromium contaminated groundwater and saturated soil using stabilized iron sulfide nanoparticles. Journal of Environmental Management, 231, 679-686.

Wu, L.-K., Wu, H., Zhang, H.-B., Cao, H.-Z., Hou, G.-Y., Tang, Y.-P., Zheng, G.-Q. 2018. Graphene oxide $/ \mathrm{CuFe}_{2} \mathrm{O}_{4}$ foam as an efficient absorbent for arsenic removal from water. Chemical Engineering Journal, 334, 1808-1819.

Xiao, X., Wang, Q., Owens, G., Chiellini, F., Chen, Z. 2019. Reduced graphene oxide/iron nanoparticles used for the removal of $\mathrm{Pb}$ (II) by one step green synthesis. Journal of Colloid and Interface Science, 557, 598-607.

Xie, Y., Cheng, W., Tsang, P.E., Fang, Z. 2016. Remediation and phytotoxicity of decabromodiphenyl ether contaminated soil by zero valent iron nanoparticles immobilized in mesoporous silica microspheres. Journal of Environmental Management, 166, 478-483. 
2111

2112

2113

2114

2115

2116

2117

2118

2119

2120

2121

2122

2123

2124

2125

2126

2127

2128

2129

2130

2131

Xie, Y., Fang, Z., Cheng, W., Tsang, P.E., Zhao, D. 2014. Remediation of polybrominated diphenyl ethers in soil using $\mathrm{Ni} / \mathrm{Fe}$ bimetallic nanoparticles: Influencing factors, kinetics and mechanism. Science of The Total Environment, 485-486, 363-370.

Xingu-Contreras, E., García-Rosales, G., García-Sosa, I., Cabral-Prieto, A. 2020. Degradation of methyl orange using iron nanoparticles with/without support at different conditions. Microporous and Mesoporous Materials, 292, 109782.

Xiong, T., Yuan, X., Wang, H., Leng, L., Li, H., Wu, Z., Jiang, L., Xu, R., Zeng, G. 2018. Implication of graphene oxide in Cd-contaminated soil: A case study of bacterial communities. Journal of Environmental Management, 205, 99-106.

Xu, L., Yang, Y., Li, W., Tao, Y., Sui, Z., Song, S., Yang, J. 2019. Three-dimensional macroporous graphene-wrapped zero-valent copper nanoparticles as efficient micro-electrolysis-promoted Fenton-like catalysts for metronidazole removal. Science of The Total Environment, 658, 219233.

Xu, Q., Li, W., Ma, L., Cao, D., Owens, G., Chen, Z. 2020. Simultaneous removal of ammonia and phosphate using green synthesized iron oxide nanoparticles dispersed onto zeolite. Science of The Total Environment, 703, 135002.

Yang, B., Zhou, P., Cheng, X., Li, H., Huo, X., Zhang, Y. 2019. Simultaneous removal of methylene blue and total dissolved copper in zero-valent iron $/ \mathrm{H}_{2} \mathrm{O}_{2}$ Fenton system: Kinetics, mechanism and degradation pathway. Journal of Colloid and Interface Science, 555, 383-393.

Yang, S.-T., Chang, Y., Wang, H., Liu, G., Chen, S., Wang, Y., Liu, Y., Cao, A. 2010. Folding/aggregation of graphene oxide and its application in $\mathrm{Cu}^{2+}$ removal. Journal of Colloid and Interface Science, 351(1), 122-127.

Yap, P.L., Tung, T.T., Kabiri, S., Matulick, N., Tran, D.N.H., Losic, D. 2020. Polyamine-modified reduced graphene oxide: A new and cost-effective adsorbent for efficient removal of mercury in waters. Separation and Purification Technology, 238, 116441.

Zambianchi, M., Durso, M., Liscio, A., Treossi, E., Bettini, C., Capobianco, M.L., Aluigi, A., Kovtun, A., Ruani, G., Corticelli, F., Brucale, M., Palermo, V., Navacchia, M.L., Melucci, M. 2017. Graphene oxide doped polysulfone membrane adsorbers for the removal of organic contaminants from water. Chemical Engineering Journal, 326, 130-140.

Zghal, S., Jedidi, I., Cretin, M., Cerneaux, S., Abdelmouleh, M. 2020. One-step synthesis of highly porous carbon graphite/carbon nanotubes composite by in-situ growth of carbon nanotubes for the removal of humic acid and copper (II) from wastewater. Diamond and Related Materials, 101, 107557.

Zhang, M., Wang, Y., Zhao, D., Pan, G. 2010. Immobilization of arsenic in soils by stabilized nanoscale zero-valent iron, iron sulfide $(\mathrm{FeS})$, and magnetite $\left(\mathrm{Fe}_{3} \mathrm{O}_{4}\right)$ particles. Chinese Science Bulletin, 55(4), 365-372.

Zhang, Z., Chen, H., Wu, W., Pang, W., Yan, G. 2019. Efficient removal of Alizarin Red S from aqueous solution by polyethyleneimine functionalized magnetic carbon nanotubes. Bioresource Technology, 293, 122100.

Zhao, G., Ren, X., Gao, X., Tan, X., Li, J., Chen, C., Huang, Y., Wang, X. 2011. Removal of Pb(ii) ions from aqueous solutions on few-layered graphene oxide nanosheets. Dalton Transactions, 40(41), 10945-10952.

Zhao, X., Jia, Q., Song, N., Zhou, W., Li, Y. 2010. Adsorption of Pb(II) from an aqueous solution by titanium dioxide/carbon nanotube nanocomposites: kinetics, thermodynamics, and isotherms. Journal of Chemical \& Engineering Data, 55(10), 4428-4433.

Zhu, F., Li, L., Ma, S., Shang, Z. 2016. Effect factors, kinetics and thermodynamics of remediation in the chromium contaminated soils by nanoscale zero valent $\mathrm{Fe} / \mathrm{Cu}$ bimetallic particles. Chemical Engineering Journal, 302, 663-669.

Zou, H., Hu, E., Yang, S., Gong, L., He, F. 2019. Chromium(VI) removal by mechanochemically sulfidated zero valent iron and its effect on dechlorination of trichloroethene as a co-contaminant. Science of The Total Environment, 650, 419-426. 